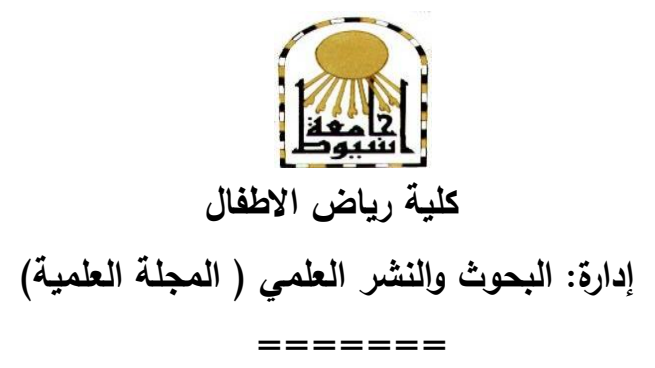

\title{
أثر أستفدام استراتيجية التعلم التعاونى فى تنمية بعض المهارات الفنية لدى طفل الروضة
}

\author{
إعـداد \\ أ. م .د/ عبيز سموه عبد المميد \\ أ.د/ ماجدة هاشمبم بخيت \\ أستاذ وعميد كلية رياض الأطفال أستاذ المناهج وطرق تدريس التربية الفنية المساعد \\ كلية التربية - جامعة أسيوط \\ كلية رياض الأطفال - جامعة أسيوط
}

آ شيرين مصمود قبد المميد

باحثة ماجستير - بقسم تربية الطقل

كلية التربية - جامعة أسيوط

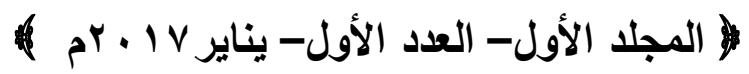


أ. أد/ ماجدة هاشم بخيت

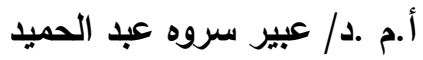

أثز أستخدام استراتيجية التعلم التعاونى

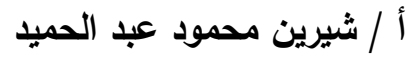

ملخص الدراسة

هدفت الدراسـة الحاليـة إلى إعداد برنـامج للتعـرف على أثر اسـتخدام اسـتراتيجية التعلم

التعاونى فى تتمية بعض المهارات الفنية لدى طفل الروضة ، كما تم أستخدام الأدوات التالية :

( قائمة المهارات الفنية المناسبة لطفل الروضـة ، مقياس المهارات الفنية لطفل الروضـة ،

بطاقة ملاحظة لأداء الطفل للمهارات الفنية ، البرنامج للتعرف على أثز استخدام استراتيجية التعلم التعاونى فى نتمية بعض المهارات الفنية لدى طفل الروضة ، دليل المعلمة ) .

و تكونت عينة الدراسة من( ع ) طفل وطفلة من أطفال روضة نجع سبع المشتركة التابعة

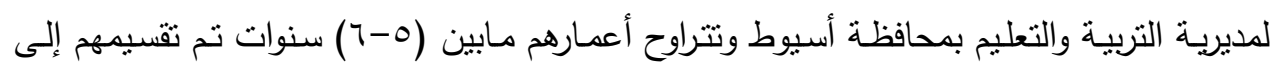

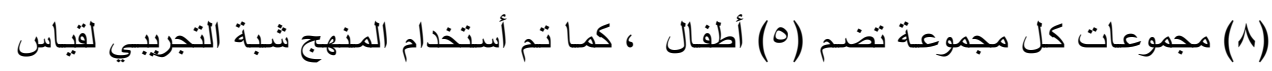
أثراستخدام التعلم التعاوني في تتمية بعض المهارات الفنية لاي أطفال الروضة ، وتوصلت الدراسة للنتائج التالية : n

(يوجد أثر لاستخدام استراتيجية التعلم التعاونى فى تتميـة بعض المهارات الفنيـة للدى

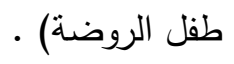




\section{Summary}

The current study aimed at preprae the effect of a using co-operative learning stertagy in developing some art skills for kindergartener, and the tool is (List the appropriate art skills of kindergartener, The art skills of the kindergartner scale, observation card for the performance of the kindergartener for art skills., program to see the effect of the use of cooperative learning stertagy in the development of some art skills of kindergartener, Teacher guide book), The sample of the present study consisted of 40 boys and girls they were divided into(8) groups each group include (5) kindergarteners, from Nage Sabe kindergarten which follows the ministry of education in Assiut city

With average between (5-6)years, and use the semi- expermintal to mesure the Effect of the use of Co- operative Learing stertagy in developing some Art SKills for Kinder gartener ,The present study reached the following results:

(Effect of the use Co- operative Learning stertagy in developing some Art SKills for Kinder gartener) .

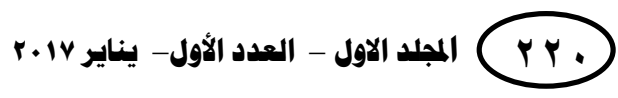




\section{مقدمـة الاراســة:}

تحتل رياض الأطفال موقعا استراتيجيا كمؤسسة تربويـة، فهى من أهم المراحل العمرية فى حياة الطفل لأنه توضـع فيها اللبنـات الأولى للشخصية، ونظرا لأن الروضـة مجتمـع مصغر فأنها تؤثز فى صفاته الإجتماعية حيث أن الطفل بطبعه أنانى يحب ذاته ، يجب غرس فيه حب التعاون واحترام حقوق الآخرين والنظام لأنه يكون قابلا للنطور والنمو واكتساب مهارات ومفاهيم جديدة وذللك

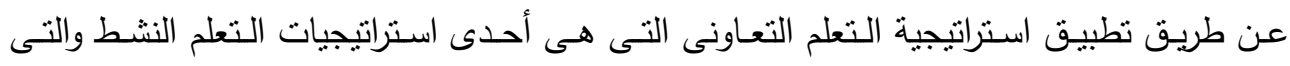
تتضمن التعاون بين اطفال المجموعة الواحدة لتتمية مهاراتهم الفنية.

كما أنها ترسم أبعاد شخصيته وتبنى فيها أساسيات المفاهيم والمعارف والخبرات والميول والأتجاهـات، لذا فـان المفـاهيم المفاهيم والمهارات المناسبة للطفل ترتبط بصـفة أساسية بحواسـهـ

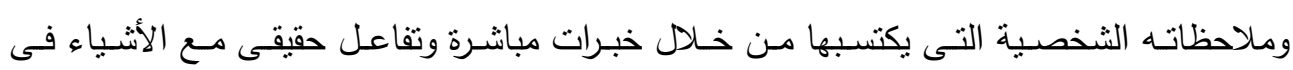

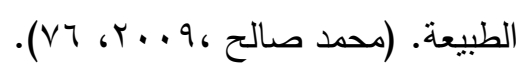

وتُعد الروضـة هـى البيئة الثانية التى ينتقل إليها الطفل بعد البيئة المنزلية وفيها يجد دائرة

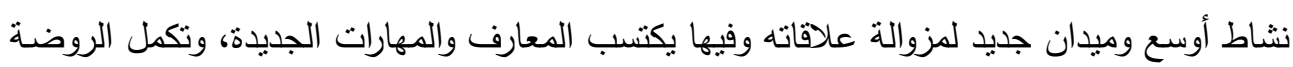
وظيفة المنزل فى تشكيل شخصية الطفل ونطويرها من حيث تتمية الميول والاتجاهات ونظرا لأن الروضة مجتمع مصغر فإنها تؤثر فى الصفات الأجتماعية للطفل كالمحافظة على النظام واحترام

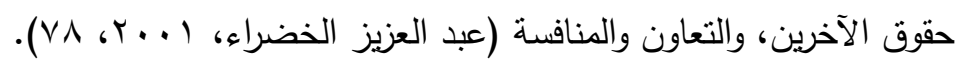
ولابد لمعلمة الروضة من توظيف أساليب التربية المختلفة والأنشطة والموجهه تربويا لمساعدة الطفل على أكتساب بعض المهارات التى لايستطيع أن يكتسبها، فلابد من غرس التعاون فى نفوس الأطفال وتقديرالعمل اليدوى (جوزال عبد الرحيم ، ... . ب، ج).

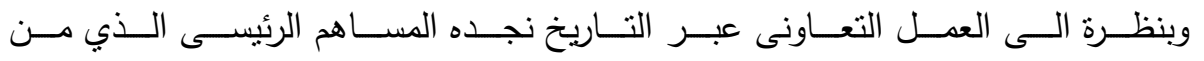
خلالـه اسـتطاع الأفـراد أن يخططـوا وبنسـقوا وبنظمـوا جهـودهم لتحقيـق غايـات مشـتركة، كـان

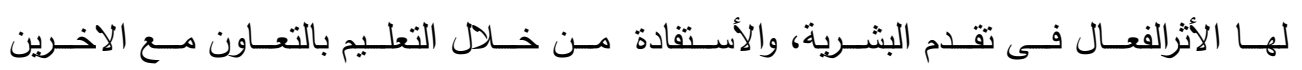

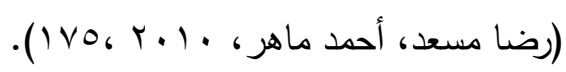




\section{المجلة العلمية لكلية رياض الاطفال - جامعة اسيوط}

وللتعلم التعاونى أهمية تتمثل فى تحقيق نتائج غير معرفية مرغوبة ومأمولة كأهداف تربوية

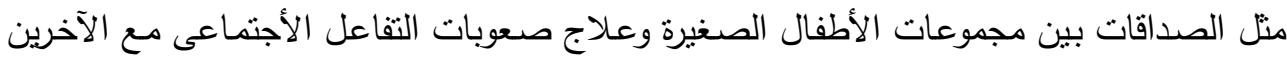
كما أنه ينمى القدرة على تطبيق ما ينعلمه فى مواقفف جديدة وينمى القدرة الأبداعية لدى الأطفال ويؤدى لحب المادة والمعلم (Robert e slavin, 1991,p.12).

كما يعتبر التعلم التعاونى أحد الأتجاهات التى توفر التفاعل الأجتماعى بين المتعلمين وكذلك الوسيلة الأساسية لأعادة تتظيم البنية المعرفية للمتعلمين والأدارة فى نتظيم المجتمعات والجماعات التهات

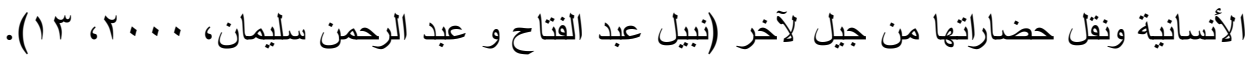

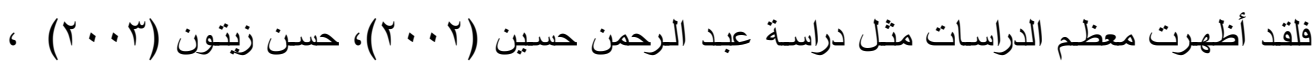

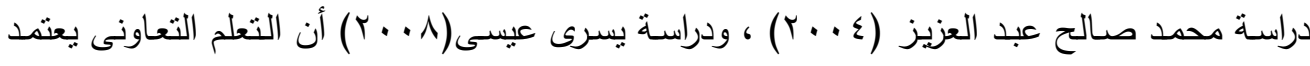

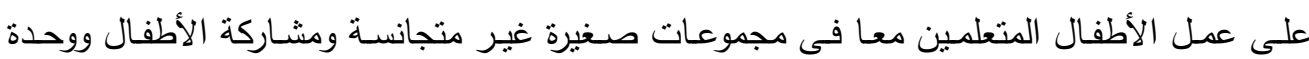

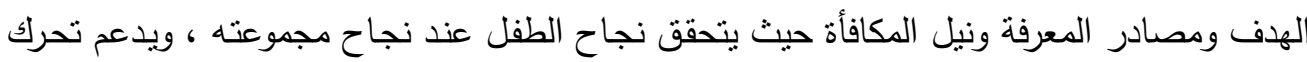

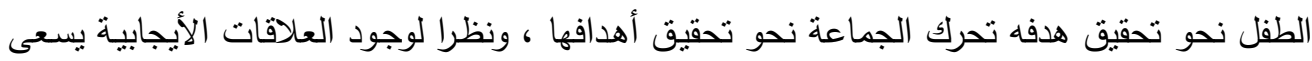

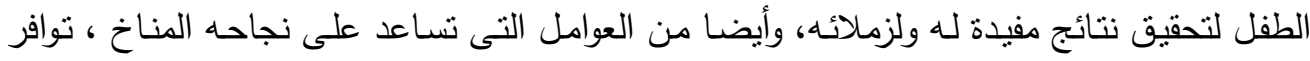

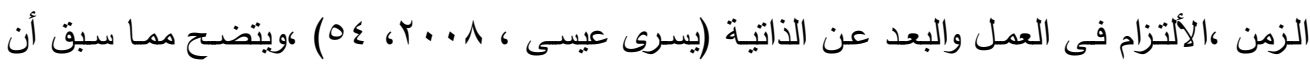

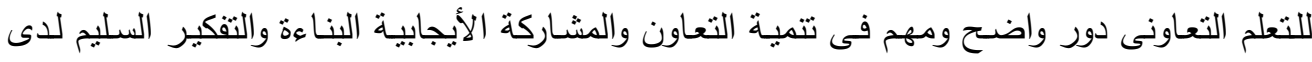

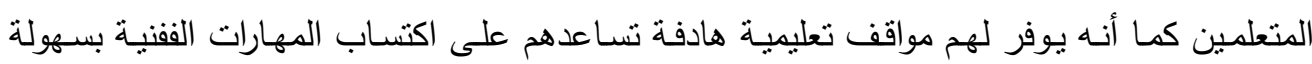

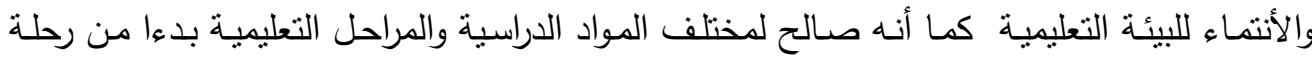
رياض الأطفال وحتى التعليم العالى.

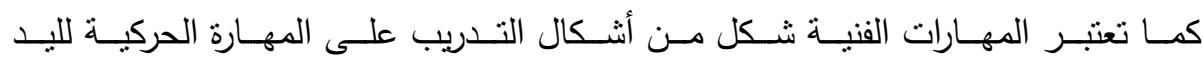
والأصابع والذراع الذى يستخدم كمدخل للتعلم وتتمية المهارات كما تتميز المهارة الفنية عن غيرها من المهارات لكونها قابلة للملاحظة للمباشرة وتظهر العديد من المهارات التى يجب أكسابها لأطفال

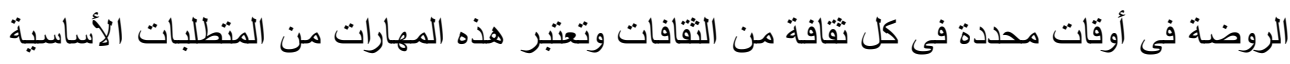

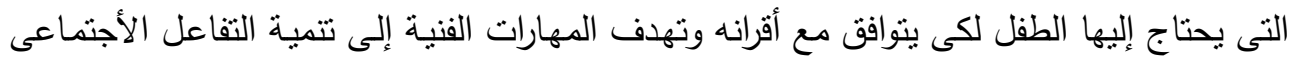

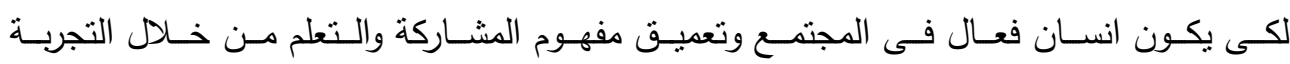

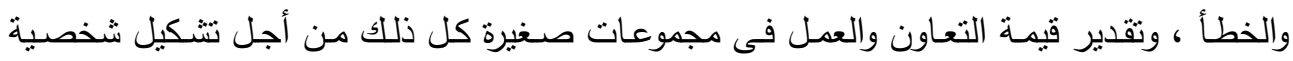

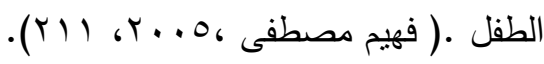


ولمـا كانت الممارسـات الفنية لطفل الروضـة من خـلال قيامسه ببعض أنشطة التربيـة الفنبـة

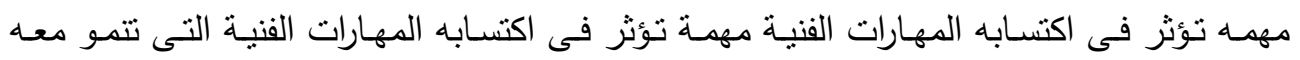

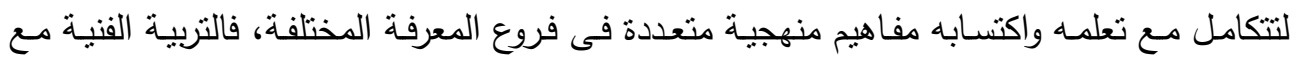
المقررات الدراسية الآخرى تسـهم فـى جميع مراحل التعليم فهى تتميـة الأسـتعدادات لدى الأطفـال وتوجهرم الوجهة التعليمية السليمة (Carolyn holm,1998,62) إن لممارسة المهارات اليدوية والفنية دوراً فعالاً وحيوياً بالنسبة لطفل الروضة، فطفل السادسة

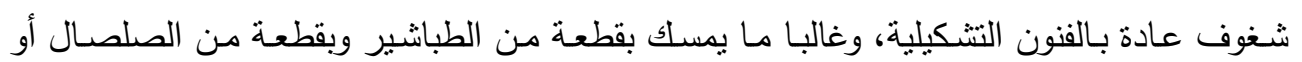
مجموعة من الألوان وقد انهك يخطط ويخلق منها عملاً جديداً خاصاً به،، وهو في كل هذا مرح ومسرور ، ولا يعنيه سوء حسن التكيف والانسجام مع العالم الذي يعيش فيه.

فـإن المهـارات تعـد الوسـيلة المباشـرة للتفاعـل بسـهولة مـع المواقـف الحقيقيـة للحيـاة، على أسـاس أن المهـارات تعنـي السـهولة والدقـة فـي إجـراء الأعمـال، وحتـى بالنسـبة للمواقـف

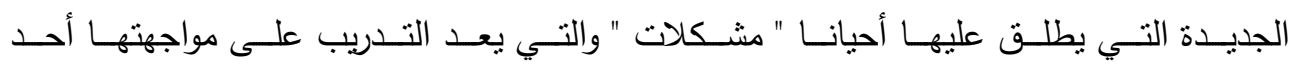

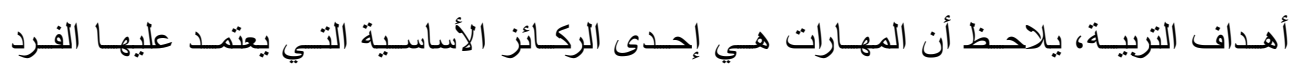
في منتل هذه المواقف.

وهذا ماأكد عليه جودى هير ( Judy Herr ) إن النشاط الفني اليدوي نشاط ممتع بالنسبة للأطفال ، لذلك فهم يريدون قضاء وقت في ممارسـة الأنشطة الفنية ويجب تشجيع الأطفال على هلى تجريب المواد المختلفة كما أكد بعض علماء التربية على أهمية المهارات والفنية لطفل الروضـة ، فقد اهتم كل من فرويل ومنتوري ودكرولي بالمهارات اليدوية بتقديم إسهامات واضحة في هذا المجال منها هدايا فرويل وأدوات منتسوري (D.Judy Herr , 1990, 199) فيقول " فرويل " إن للطفل منذ سنينه الأولى شغفاً واضحاً بالرسم بل والتلوين وعمل النماذج كذلك، وهذا يوضح أن الفن وتقديره يكون قدرة عامة أو مهارة للإنسان ولذا فالعناية بهما واجبة . ويقول أيضـا أن الطفل يجد في أطرافه وخاصـة يديه - الأدوات التي يستطيع بها أن يحل إحساسـاته ودوافعه الداخلية إلى عالم الواقع، وعلى ذلك فإن إتاحة الفرصـة للطفل كي برسم وحثه على الرسم يعتبران من الوسائل الضرورية الفعالة لتعلم الإنسان عامة وعلى 


\section{المجلة العلمية لكلية رياض الاطفال - جامعة اسيوط}

وقد علت درجة الاهتمام عند"فرويل" بأهمية ممارسة الطفل لمناشط فنية مختلفة بأن وضع مجموعة من التدريبات والألعاب لتتمية بعض الحواس عند الطفل، مثل اللعب بواسطة الأخشاب والأعواد، الأوراق، الأشرطة، الرمال، الطين.

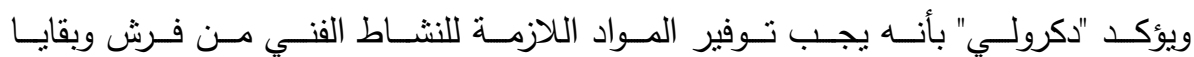

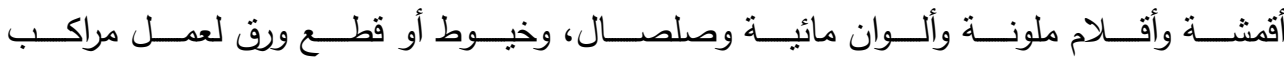
وعجلات وقطارات وحيوانات وأدوات موسيقية وأدوات منزلية وبطاقات " كروت هدايا ". (أمانى عبد ولد وليد

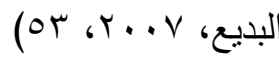

المهارات الفنيـة مثلهـا مثنل غيرهـا مـن المهارات التى لهـا دور في تتميـة شخصية الفرد

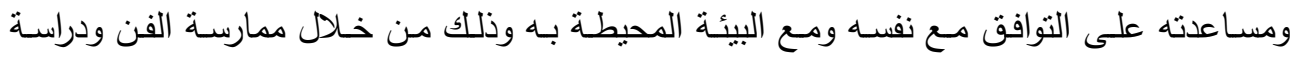
أسسه، والتعبير الحر عن الذات والمجتمع والعالم.

وتهدف المهارات الفنية إلى بنـاء الثخصية في جميع الجوانب العقلية والنفسية والحركية والعاطفية والإدراكية والاجتماعية والإبداعية والجمالية. وتضم التربية الفنية مجموعة من المعارف والمهارات والقيم التي تدعم قدرات التعبير الابتكارى، ومهارات التواصل والتقافة البصرية والتذوق

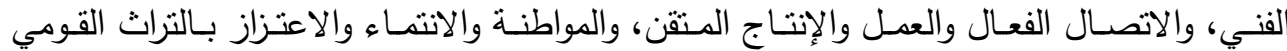

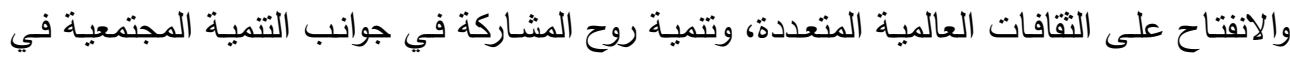
عالم سريع التغير قائم على التنافس وإتقان العمل وضمان الجودة في مختلف المجالات. "والمهارات الفنية بأنواعها وفروعها لها مكانة عظيمة في هذا المجتمع، وذلك باعتباره مظهراً من مظاهر القيم الجمالية والحضارية، وعاملا فعالاً يساعد على تتمية الحس، واكتساب الخبرة والدقة عند كل فرد. ولكل شعب من الثعوب فنونه الني تعبر عن أحاسيسه ومشاعره وعن آلامهه وآماله وعن أفكاره وطموحه" (حمدى خميس، ع . . ؟، . 0). ومن هذه المهارات التى تتميها الدراسة (مهارة التلوين - مهارة القص واللصق - مهارة الطباعة). ومن هذا المنطلق تعتبر استراتيجية التعلم التعاونى من أهم الأستراتيجيات المناسبة لطفل

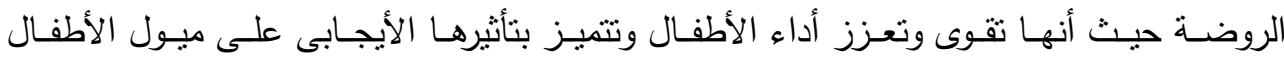
واتجاهاتهم كمـا تسـاعد على تكوين صداقات بين مجموعـات العهل العهل وبالتالى يسهـل تتميـة

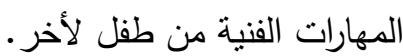




\section{مشكلة الدراسة:}

بعد الأطلاع على الدراسات السابقة ونتائجها وتوصياتها كالدراسات التي أثنارت إلى ضرورة

تتجيع الأطفال على تتميـة مهاراتهم الفنيـة ومن هذه الدراسـات دراسـة احمد الصـعيدى (Y 99 ( ) والتى هدفت الى تتميـة التفكير الابتكارى لدى طفل ماقبل المدرسـة من خلال حقيبة تعليميـة من

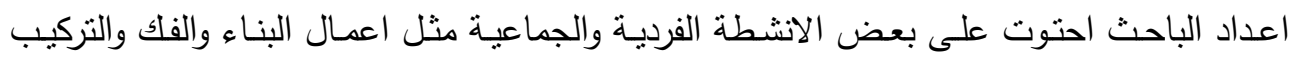

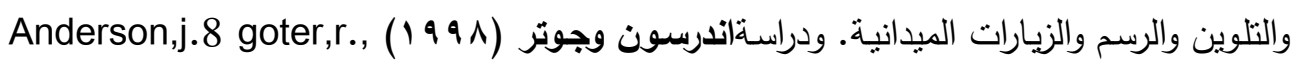
وهدفت الدراسـة الى اعداد برنـامج برنـامج فى التربيـة الفنيـة للاطفـال الذين يحتاجون الىى تعزيز للمفاهيم الاساسية التى تتاسب الاطفال من خلال حقيبة تعليمية تتضمن انشطة للتعرف على الالوان والاشكال والارقام والحروفويجرى استخدام الحقيبة فى المنزل وبمساعدة الاباء ، وقد توصلت نتائج الدراسة الى نجاح البرنامج فى تتمية المهارات الفنية الاساسية ونجاح مشاركة الاباء فى التعامل مـع الاطفـال لتتميـة المهارات الفنيـة الاساسية ، ودراسـة (Ii,v.,2001 ) وهدفت الدراسـة الى تفعيـل الانشطة الفنية لتحسين الكتابـة وتعرف ثقافة الطفل من خـلال الرسوم ، فقد اجريت الدراسـة على ودرسك عينة من اطفال الرياض فى هونج كونج بهدف تحسين قدراتهم على الكتابـة باللغـة الصينية عن طريق الانشطة الفنية وقد اظهرت النتائج ان العمل الفنى وممارسـة انشطة التذوق الفنى ادت الى هلى

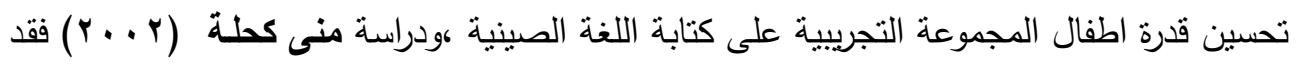
استهدفت بناء برنامج لتدريس الطباعة اليدوية لطفل الرياض من خلال النتكيل الورقى وتتمية القدرة على استخدام بعض الادوات والخامـات البسيطة في الطباعـة اليدويـة باستخدام التشكيل الورقى ،

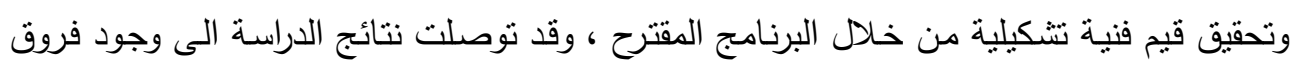
ذات دلالة فى درجات اختبار الطباعة البدوية باستخدام التشكيل الورقى وفى درجة تأثير اللون على المنتج الطبـاعى ، بالإضـافة لدرجـة القيم الفنيـة والتشكيلية وذلك لصـالح التطبيق البعدى لاطفـال

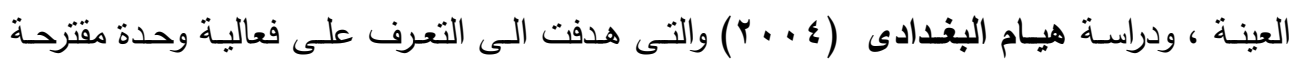

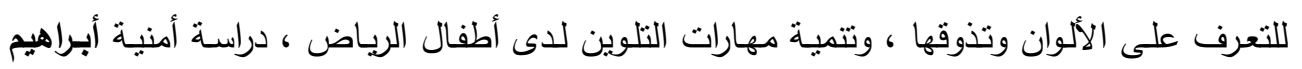

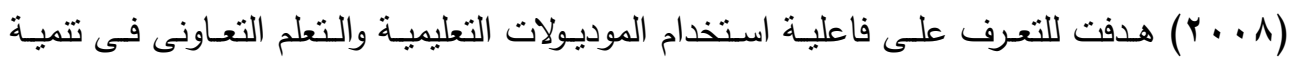
المفاهيم الفنيـة والمهارات اليدويـة والابتكار لدى طـلاب كليـة التربيـة النوعيـة شعبة التربيـة الفنيـة بمدينـة اسيوط ، ودراسـة محمد صـالح (9 . . . ( ) فقد هدفت الدراسـة للتعرف على فعاليـة استخدام 
الممارسات اليومية والمعالجات اليدوية لاطفال ماقبل المدرسة فى اكسابهم بعض المفاهيم الرياضية

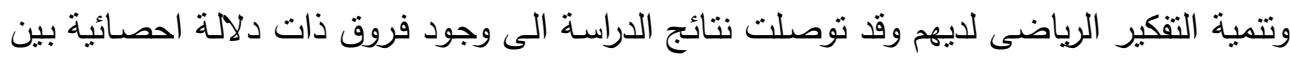

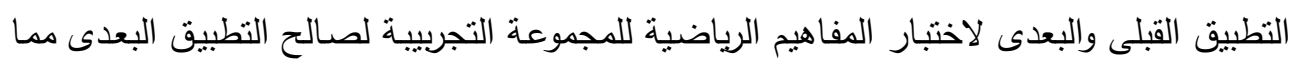

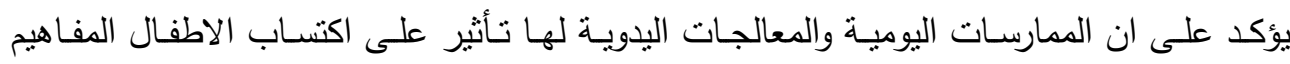

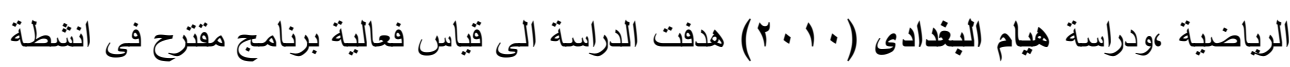

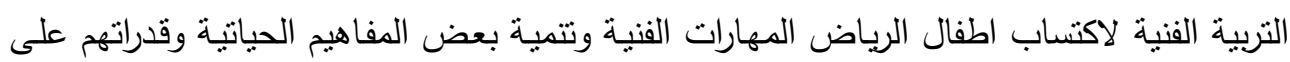

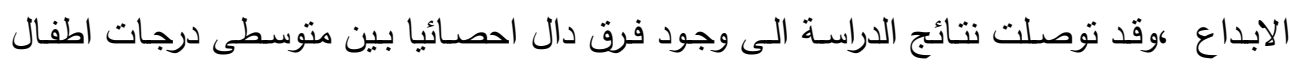

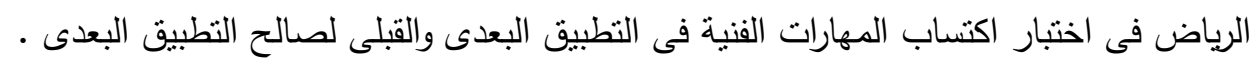
ولذلك ارتأت الدراسة الحالية أستخدام التعلم التعاونى فى تتمية بعض المهارات الفنية لطفل

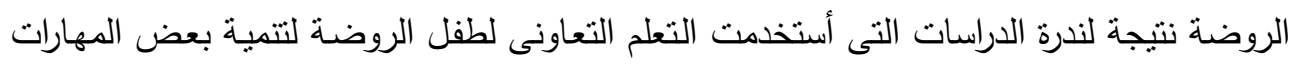

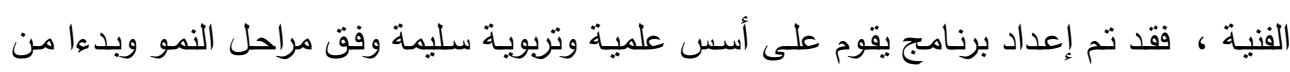

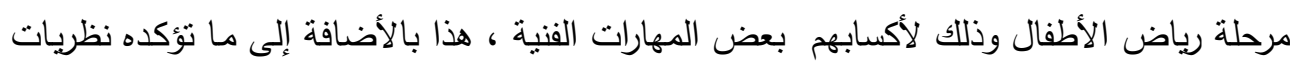

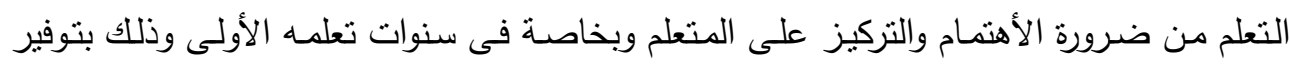

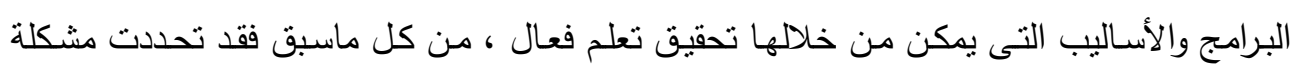
الدراسة فى تدنى مستوى أطفال الروضة في المهارات الفنية .

لذا تحاول الاراسة الإجابة عن الأسئلة التالية :

1- - ما المهارات الفنية المناسبة لطفل الروضة ؟

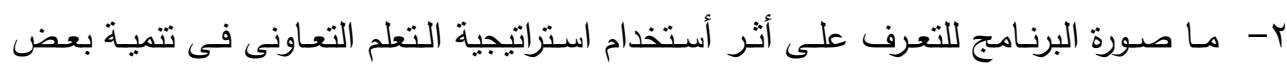

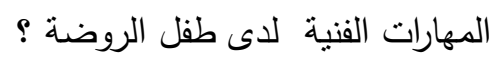

r- ما ما الفرق بين متوسطى درجات مجموعة الدراسة فى مقياس المهارات الفنبة قبل وبعد تطبيق

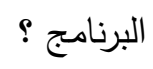

ع - مـا الفرق بين متوسطى درجـات مجموعـة الدراسـة فى بطاقـة الملاحظـة قبل وبعد نطبيـق

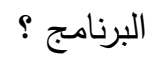




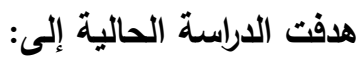

( ) التعرف على المهارات الفنية المناسبة لطفل الروضة .

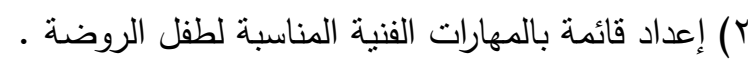

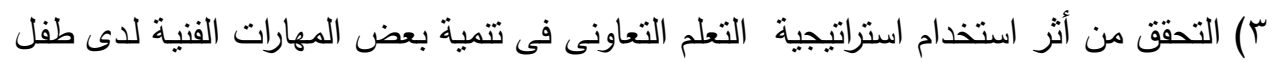
الروضة.

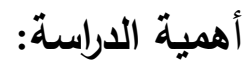

\section{تبرز أهمية الدراسة فيما يلى :}

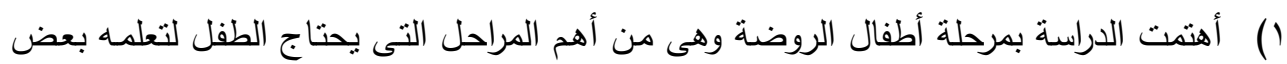

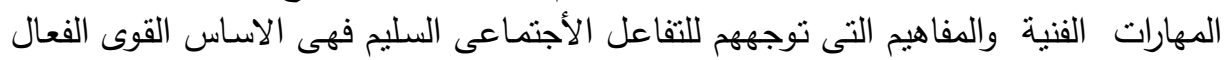
للتمهيد للعملية التعليمية فيما بعد.

r) ت تمية بعض المهارات الفنية مثل (مهارة التلوين، مهارة القص واللصق، مهارة الطباعة ). r) تعتبر محاولة لإلقاء الضوء على بعض المهارات الفنية التى تتمى من خلال استراتيجية التعلم التعاونى.

ء) تحفيز الأطفال على العمل في فريق، والاتصال الفعال، والتعلم الذاتي، اتخاذ القرار وتطبيق المعرفة في مواقف تعلم جديدة.

0) تقديم برنامج لمعرفة أثر استخدام استراتيجية التعلم التعاونى فى تتمية بعض المهارات الفنية لاى طفل الروضة.

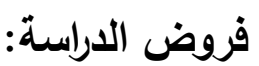

1- توجد فروق ذات دلالة احصائية بين منوسطى درجات مجموعة الدراسة فى النطبيق القبلى القيل

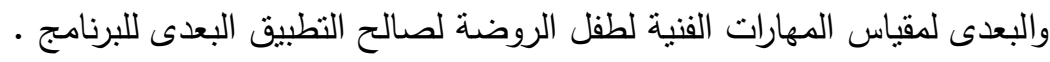

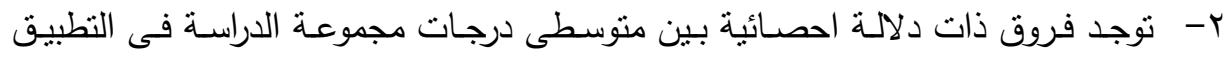

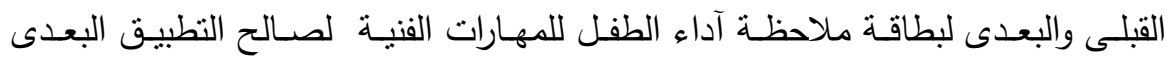
- للبرنامج r- توجد علاقة ارتباطية دالـة احصائيا بين درجات مجموعة الدراسـة فى مقياس المهارات الفنية وبطاقة الملاحظة فى التطبيق البعدى. 


\section{حدود الدراسة:}

- الددود الموضوعية: اقتصرت الدراسة على بعض الدهارات الفنية النالية :

$$
\text { (النلوين - القص واللصق -الطباعة ). }
$$

- الحدود المكانية: تم تطبيق أدوات الدراسة والبرنامج بروضة نجع سبع المشتركة التابعة لمديرية التربية والتعليم بمحافظة أسيوط.

- الحدود الزمانية: نم إجراء الدراسة الحالية في الفصل الدراسي الثانى لعام 10 • بم / 17 • ب م.

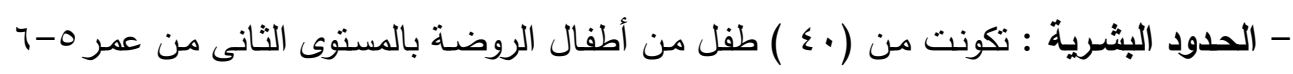

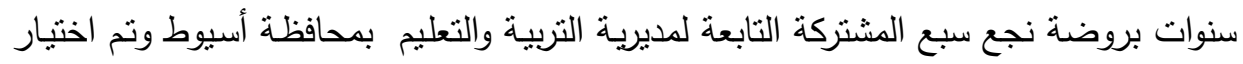

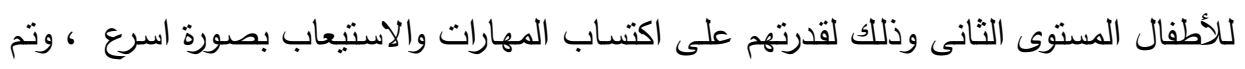

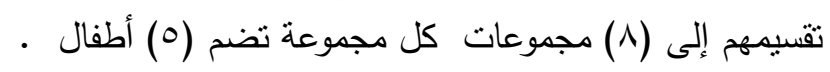

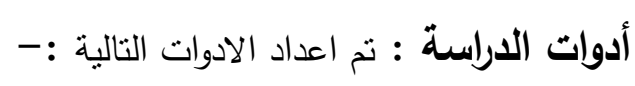

1 - قائمة المهارات الفنية المناسبة لطفل الروضة .

r- مقياس المهارات الفنية لطفل الروضة .

r- بطاقة ملاحظة لأداء الطفل للمهارات الفنية .

ـ - برنامج لمعرفة أثر استخدام التعلم التعاونى في تتمية بعض المهارات الفنبة لدى طفل الروضة.

ه- دليل المعلمة .

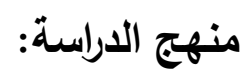

1- المنهج الوصفى التحليلى:

وذلك فى اعداد الإطار النظرى للاراسة وتحليل مجموعة الدراسات والبحوث السابقة

$$
\text { r- المنهج شبه التجريبى: }
$$

تم أستخدام المنهج شبة التجريبي القائم على المجموعة الواحدة one group ذات

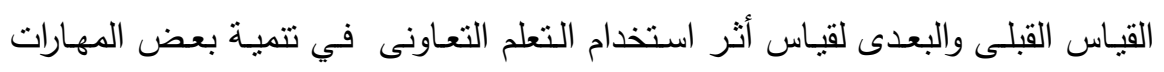
الفنية لاى طفل الروضة خلال القباس القبلي - البعدي للأطفال. 


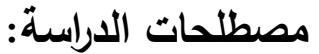

البرنامج : (البن

عرفته (هيام البغدادي، ( · r، ) البرنامج "بأنه تخطيط منظم لتحقيق أهداف معرفية

ومهارية لاكتساب التلاميذ المهارات الفنية وتتمية بعض المفاهيم الحياتية والقدرة على الإبداع"). وتعرف الدراسـة الحالية البرنامج إجرائياً بأنه مجموعة من اللقاءات والخطوات والإجراءات المنتظمة التي يتلقاها الأطفال بهدف تتمية بعض المهارات الفنية لاى طفل الروضة بإستخدام التعلم

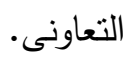

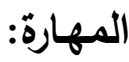

تعرف المهارة في مجال الفنون بأنها قدرة التلميذ على التعبير الفني من خـلال الخطوط

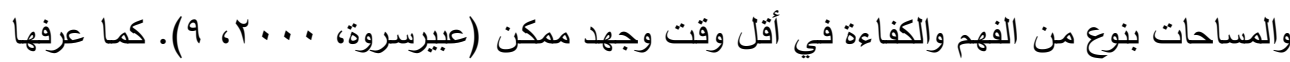

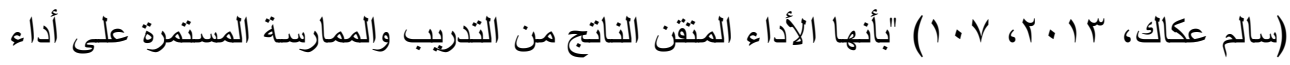

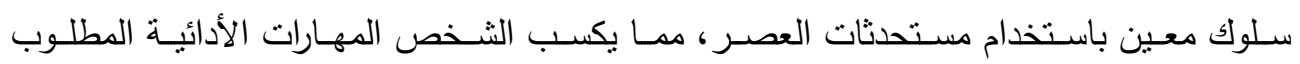

وتعرف الدراسـة الحالية المهارة إجرائياً على أنها قدرة الطفل على أنتاج أعمال فنية يدوية

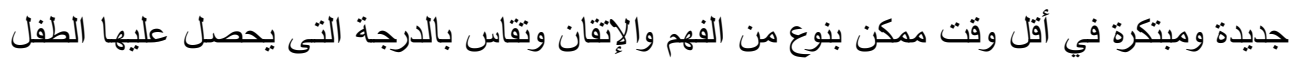

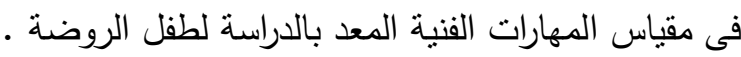

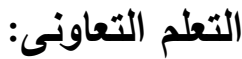

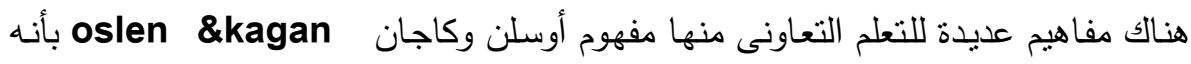
تنظيم أنشطة تعليمية فى مجموعات لكى يصبح المتعلم معتمدا على بناء اجتماعى وعلى تبادل

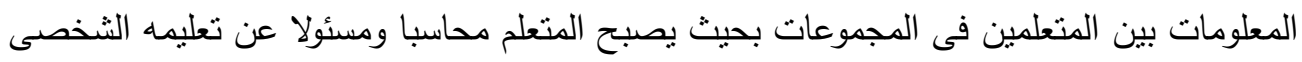

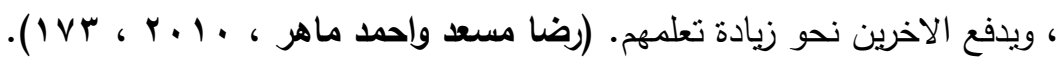


تعددت تعريفات التعلم التعاونى واتفقت جميعها على أنه أسلوب تعليمى يقوم على تتظيم

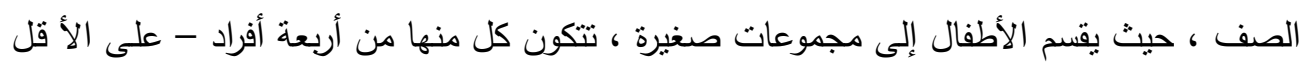

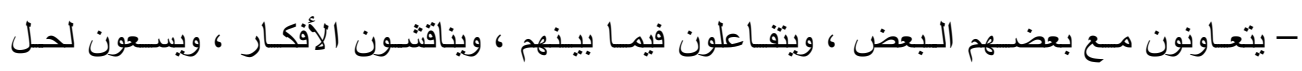

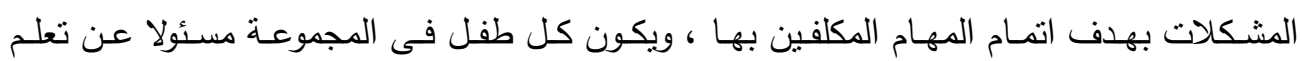

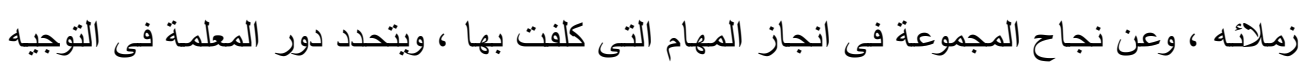

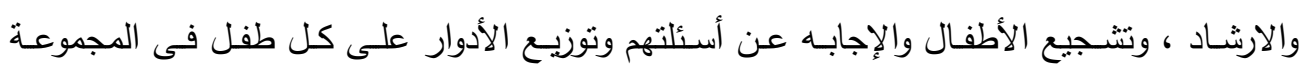

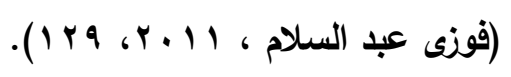

ويعرف فى هذه الاراسة على أنه طريقة تعلم تقوم على تتظيم أنشطة تعليمية فنية يتم فيها تقسيم الأطفال الى مجموعات صغيرة غير متجانسة (مختلفى القدرات والاستعدادات والميول) تتكون

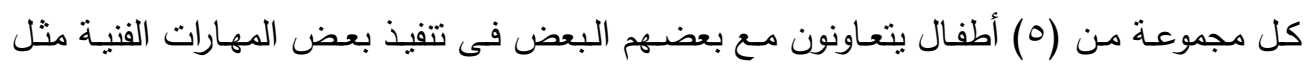

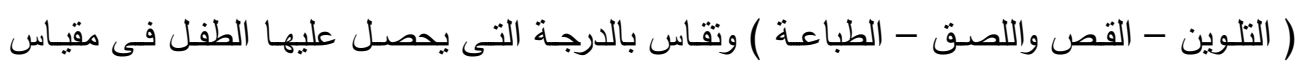
المهارات الفنية لطفل الروضة المعد بالدراسة الحالية لقياس أداء الطفل للمهارة الفنية .

\section{تعريف المهارة الفنية:}

\section{وهناك عدة تعريفات للمهارة القنية منها:}

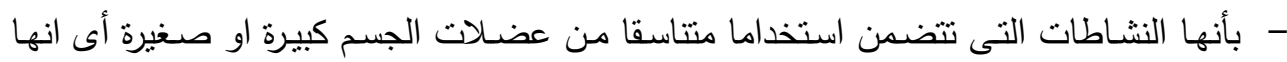

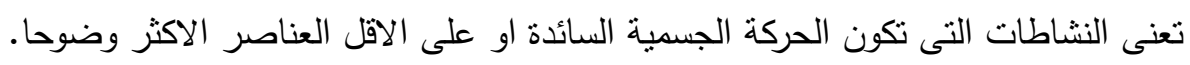

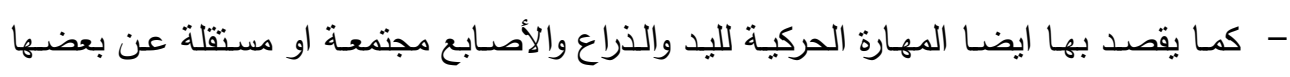

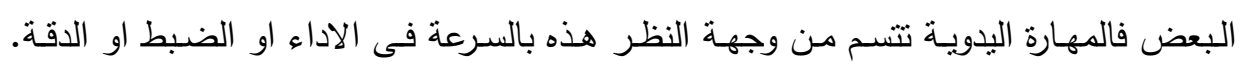

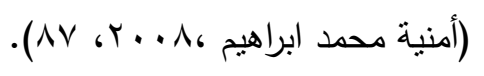

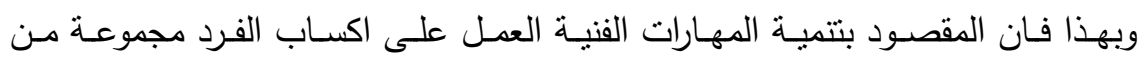

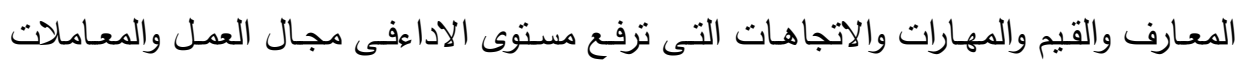

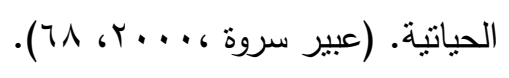


أ. أ.د/ ماجدة هاشم بخيت

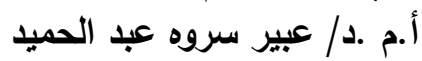

أثز أستخدام استراتيجية التعلم التعاونى

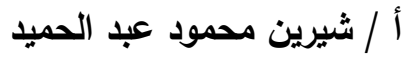

وتقتصر المهارات الفنية فى الاراسة الحالية على :

مهارات (الطباعة ، التلوين ، القص واللصق) .

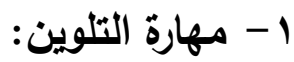

تتبنى الدراسة الحالية تعريف سميرة أبو زيد وسحر توفيق ، ؛ . . ب ) لمهارة التلوين

إن الطفل بطبيعتة يهوي رؤية الألوان والعبث بها وتفحصها واستخدامها في تلوين الأشياء

المختلفة وهنا يجب على المعلمة أن تعرفه بأنواعها المختلفة.

تدريب الطفل على التلوين في اتجـاة واحد وعدم الخروج عن الإطـار المحدد وضـرورة

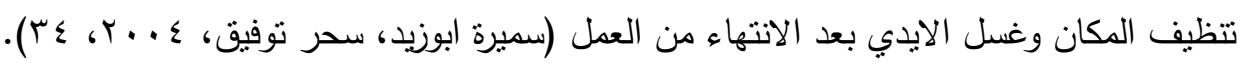
وأيضا معرفة الطفل للألوان ودرجاتها عن طريق خلطها ببعض، والتحكم فى اللون داخل

المساحة.

فيجب مراعاة أن تكون:

- موضوعات النلوين مشوقة وجذابة ومناسبة لمستوى نمو الطفل.

- - أن تكون مساحة الصورة المراد تلوينها كبيرة ومناسبة لتعطى الطفل حرية الحركة فى التلوين. - كمـا تتطلب أنشـطة التلـوين خامـات مختلفـة كـالريش، الفرشـاة ، الأقـلام الثـمعية، الأقـلام الخشبية، أقلام الفلوماستر ، الألوان المائية.

\section{r- مهارة القص واللصق: - ب}

تعرفه الدراسة الحالية :

هـو ممارسـة الطفـل لأعمـال القص واللصـق والقطـع لـلأوراق الملونـة وغيـره مـن أوراق المجلات والصحف والكتب ولصقها بصورة جمالية فى لوحة صغيرة من عمل الطفل.

وفى هذه المهارة يمكن لأطفال أستخدام الخامات التالية : 
1- أوراق القص واللصف العادية ويمكن ترك الحرية للأطفال لكى يقصوا الأشكال التى يريدونها

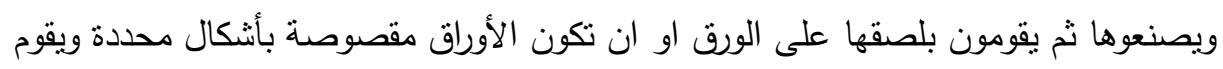
الأطفال بلصقها على الورق بشكل جمالى.

r- بعض الأثكال المرسومة على ورق مقوى حيث يقوم الأطفال بقصها ولصقها. كما يمكن أيضا توزيع بعض صحف المجلات والقصص ووضع دوائر على بعض هذه

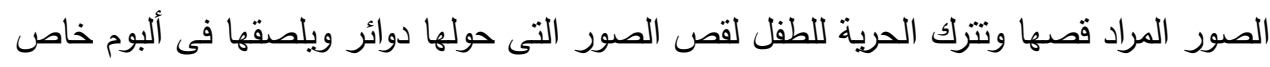
به وبهذا يسنطيع الأطفال أن يكونوا ألبوم لصور الحيوانات وألبوم لصور الطيور وألبوم للأشكال الهندسية.

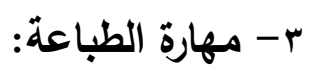

تعرفها الدراسة الحالية بأنها :

تطبيق الطفل للتصميمات المفرغة على ورق استتسل لطباعتها على القماش أو الورق

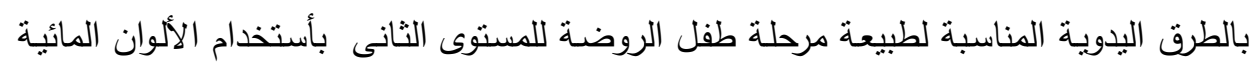
والمدقات الأسفنجية.

وأيضا الطباعة باستخدام الألوان المائية وورق الثجر على الورق أو القماش بالطرق اليدوية المناسبة لطبيعة هذه المرحلة .

$$
\begin{aligned}
& \text { وفى هذه المهارة أيضا يمكن أستخدام خامات متعددة منها: } \\
& \text { (تصميمات مفرغة - ألوان مائية - مدقات أسفنجية - ورق شجر ) }
\end{aligned}
$$

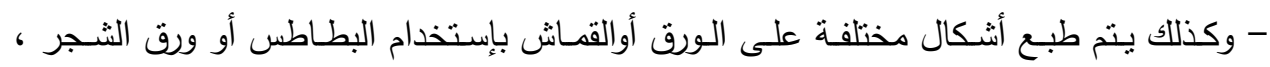

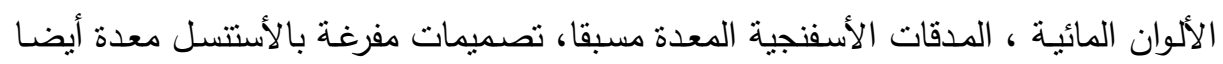

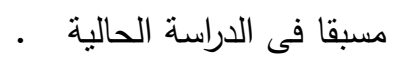


أ.د أد/ ماجدة هاشم بخيت

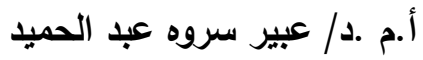

أثر أستخدام استراتيجية التعلم التعاونى

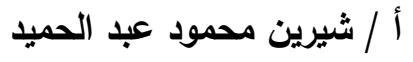

\section{إجراءات الدراسة:}

ا - الإطـلاع على الدراسـات والبحوث السـابقة التي تضـنت البرامج التربويـة وبـرامج التربيـة

الفنية.

• ب - ب إعداد أدوات الدراسة الحالية

r- عرض الأدوات فى صورتها المبدئية على التحكيم ، ومن ثم تعديلها .

؟ - تحديد مجموعة الدراسة .

0- تطبيق الأدوات على مجموعة الدراسة .

؟- التحقق من فروض الدراسة وفقا لنتائج تطبيق أدوات الدراسة .

مجموعة الدراسة:

تضــنت الدراسـة الحاليـة مجموعـة اسـنطلاعية بخـلاف المجموعـة الأساسـية لتقنين أدوات الدراسة ،وتم من خلال المجموعة الأساسية اختبار فروض الدراسة ومناقتشة وتقسير نتائجها.

\section{• (المجموعة الاستطلاعية:}

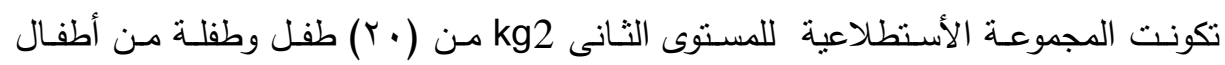

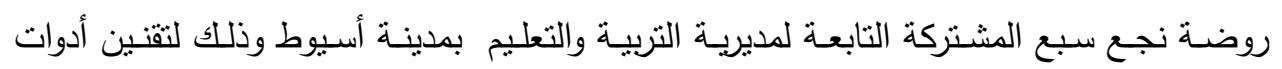
الدراسة مورة

\section{• المجموعة الأساسبة:}

تكونت المجموعة الأساسية من ( • ) طفلاً من أطفال الروضسة وتم تقسيمهم إلى ثمـان

مجموعات كل مجموعة تضم (0) أطفال من أطفال روضة نجع سبع المشتركة بمدينة أسبوط . 


\section{إعداد أدوات الدراسة : n}

\section{1- إعداد قائمة بالمهارات الفنية :}

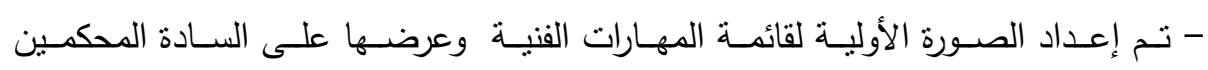

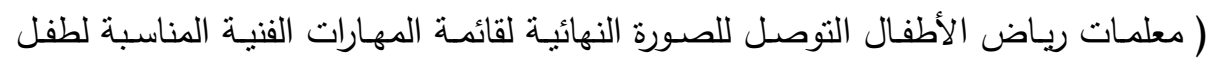

$$
\text { والروضة بعد عمل التعديلات اللازمة في ضوء آراء الدحكمين. }
$$

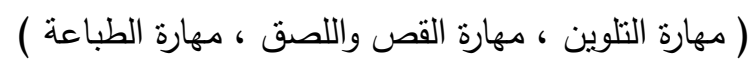

r- مقياس المهارات الفنية لطفل الروضة :

- خطوات إعداد مقياس المهارات الفنية:

تم اتباع الخطوات الآتية في إعداد المقياس:

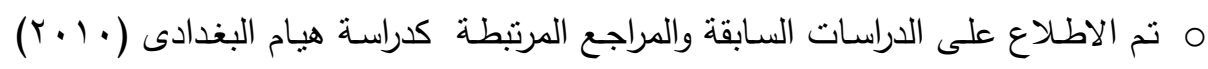

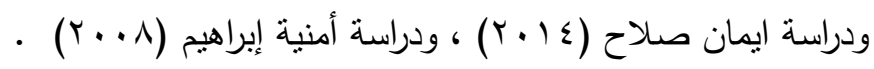

م مداد مقياس المهارات الفنبة، وقد راعت صياغة المقياس الآتي:

- تحديد التعريفات الإجرائية التي يحتويها المقياس، وذلك باستخدام الكلمات ذات المعنى

$$
\text { الواضح والمحدد. }
$$

- ثم تجزئة الأبعاد الرئيسة إلى عبارات فرعية محددة، لتحقيق سهولة الحكم والقياس. - ثم بناء وصياغة المقياس على أساس التقييم الفردى لكل طفل من أطفال المجموعة. - - نم عرض المقياس على السادة المحكين وذللك لأخذ آرائهم فى مدى مناسبة هذه المهارات

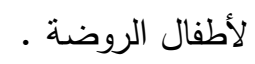

- - تطبيق قبلى لمقياس المهارات الفنية على (المجموعة الاستطلاعية) للتأكد من صدق وثبات المقياس ومعرفة زمن تطبيقه. 
أ.د أد/ ماجدة هاشم بخيت

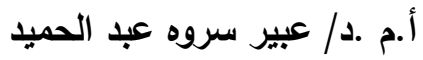

أثر أستخدام استراتيجية التعلم التعاونى

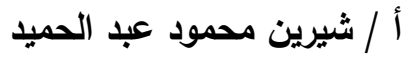

ب- وصف المقياس :

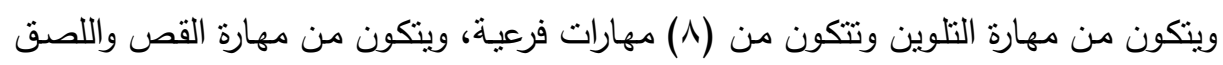

وتتكون من (^) مهارات فرعية، ويتكون من مهارة الطباعة وتتكون من من (^) مهارات فرعية.

ج- الهذف من المقياس :

ويهـدف المقيـاس بأبعـاده لقيـاس المهارات الفنيـة التاليـة لأطفـال الروضـة مـن عمر (0-7)

سنوات:

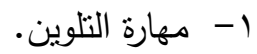

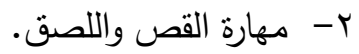

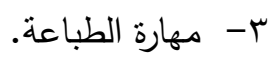

د- زمن تطبيق المقياس:

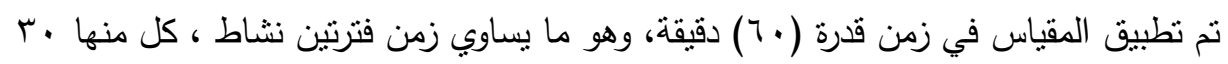
دقيقة حيث (ن = مبث ).

هـ - طريقة تصحيح المقياس:

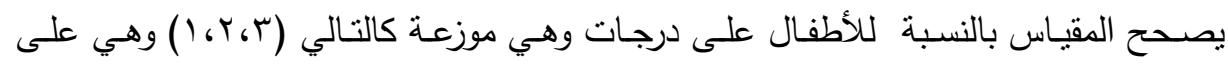

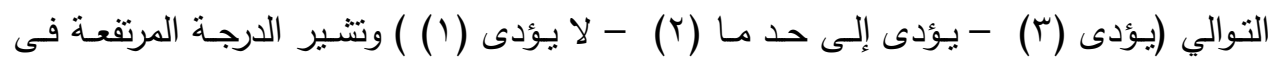

المقياس بقدرة الطفل على آداء المهارة فئى نهاية النشاطو.

و - كفاعة المقياس:

التحقق من كفاءة المقياس تم حساب المقياس عن طريق: الصدق والثبات .

- - حساب صدق المقياس :

تم حساب الصدق بطريقتين هما : 
1 - اب صدق المحكمين :

للتأكد من صدق المقياس عرضته الباحثة على مجموعه من المحكمين المتخصصين في التربية النوعية و رياض الأطفال ملحق ( ( ) لمعرفة رأيهم فيما يتعلق ب: - مدى مناسبه مقياس المهارات لطفل الروضة. - مدى وضوح عبارات المقياس في المهارات المطلوبة للبرنامج. - إعادة صباغة العبارات التى ترون إعادة صياغتها أو تعديل صياغتها اللغوية. - إضافة أو حذف أو استبدال ما يرون إضافته أو حذفه أو استبداله من قائمة المهارات. ز - تعديل القائمة وفقاً لنتائج التحكيم:

ونتيجة للتحكيم كانت هناك بعض الآراء والمقترحات للسـادة المحكمين الأخذ بها وفيما يلي عرض لبعض هذه المقترحات والآراء: • مقترحـات خاصـة بالعبـارة رقم (Y) في المهارة (التلوين) تم تعديلها إلى (يختار الألـوان

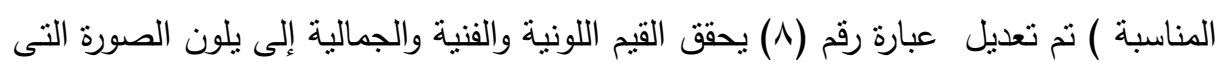
• أمانه بألوان جميلة

مقترحات خاصة بالعبارة رقم (7) في المهارة (القص واللصق) يثابر حتى ينتهى من العمل الفنى تم تعديلها إلى (يثابر حتى الأنتهاء من إنجاز العمل الفنى المطلوب ) ).

r - حساب صدق المقارنة الطرفية :

تم حساب صدق التميز لمقياس المهارات الفنية بالنسبة للمجموعة الاستطلاعية عن طريق المقارنـة الطرفيـة (بين الإربـاعي الأدنى والإربـاعي الأعلى) لمجموع (المحاور) باستخدام اختبار (ت) في المجموعات

وجد أنه دال عند مستوى ( ( . • ) مما يؤكد ارتفاع الصدق التمييزى للمقياس وقدرته على 
أ. أ.د / ماجدة هاشم بخيت

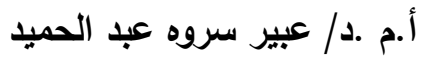

أثز أستخدام استراتيجية التعلم التعاونى

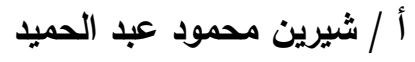

- حساب ثبات مقياس المهارات الفتية لطقل الروضة :

تم حساب ثبات المقياس بطريقتي معامل ألفا كرونباخ والاتساق الداخلي وفيما يلي عرض

للطريقتين:

ا - طريقة الاتساق الداخلي:

تم حسـاب ثبـات المقيـاس بطريقـة الاتسـاق الـاخلي وذلك عـن طريـق إيجـاد معـاملات

الارتباط بين درجة كل مهارة فرعية والمهارة الأساسية التي تتدرج تحتها، ودرجة كل محور والدرجة

الكلية للمقياس باستخدام الارتباط لبرسون ووجد أن جميع معاملات الارنباط دالة إحصائياً عند

مستوى (1 . . •) و (0. . • ) مما يؤكد على أن المقياس بتمتع بدرجة اتساق داخلي مرتفعة

ب

تم حسـاب الثبات بواسطة معادلة ألفا كرو نباخ، وبلغت قيمـة معامل الثبات للمقياس ككل

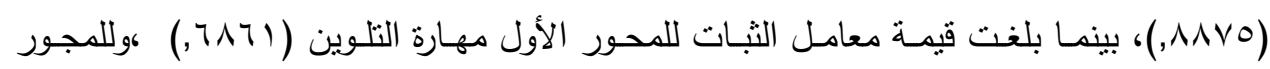

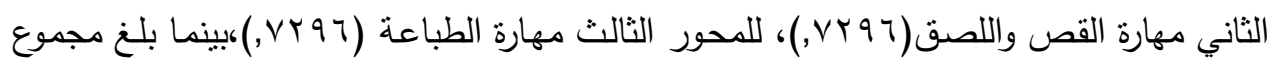

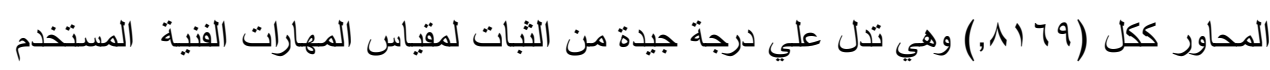
فى الدراسة الحالية .

r- بطاقة الملاحظة لآداء الطقل للمهارات الفتية :

الإطلاع علي الدراسات السابقة مثل دراسة هيام البغدادى (· • ( •) ، دراسة غادة الثريف (1) (r) نم إعداد بطاقة ملاحظة وتم استطلاع رأي المحكمين، وذلك بعرض البطاقة على مجموعة من المحكمين، وقد طلب منهم الإدلاء بآرائهم من حيث: - - وضوح ومناسبة تعليمات البطاقة. - قدرة عبارات البطاقة على قياس المهارة. - محة ودقة العبارات من الناحية اللغوية. - اقتراح ما برونه من تعديلات في بنود عبارات البطاقة أو بالنسبة للبطاقة ككل. 
ومن خلال اللقاءات مع السادة المحكمين، وجد اتفاق كبير بين آرائهم، من حيث سلامة المفردات ودقتها، وكذلك قدرة البطاقة على قياس المهارات، ومناسبة الألفاظ ووضـوحها بعد إجراء بعض من التعديلات المقترحة، لتصبح البطاقة جاهزة للتطبيق. أ- وصف بطاقة الملاحظة :

وضمت البطاقة (r) مهارات رئيسة (التلوين - القص واللصق - الطباعة ) انبثق منها (rع) مهارة فرعية مرتبطة بها. ب- الهدف من بطاقة الملاحظة: - تهدف بطاقة الملاحظة: إلى القياس الفردى لآداء أطفال الروضة للجانب المهاري لبعض المهارات الفنية مثل التلوين - القص واللصق -الطباعة .

- صياغة فقرات بطاقة الملاحظة: تم الاعتماد في صياغة عبارات البطاقة بشكل أساسي على قائمة المهارات الفنية المحدة، وقد شملت عبارات البطاقة بصورتها الأولية على (Y乏) عبارة، موزعة على ثلاثة محاور وهى( التلوين - القص واللصق - الطباعة )، وقد رُوعي عند صباغة العبارات أن تكون إجرائية، وسهلة الملاحظة،إضافة إلى تسلسلها المنطقي.

\section{ج- طريقة تصحيح البطاقة :}

- تم تسجيل أداء طفل بوضع علامة (ل) أمام مستوى الأداء المناسب لأدائه، وتم الحصول على الدرجة الكلية للاطفال بتجميع تلك الدرجات، التي يتم من خلالها الحكم على مستوى أدائه في

$$
\text { - مريقة تصحيح وتقدير الدرجات: }
$$

وقد حددت الباحثة مقياس الأداء ب(ب، r، ( )، حيث نشير الدرجة (1) إلى أن الطفل لم يؤدي المهارة، والدرجة (Y) على أنه أدي المهارة إلى حد ما، والدرجة (r) على أنه أدي المهارة

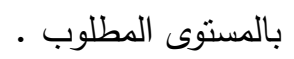


أ.د/ ماجدة هاشم بخيت

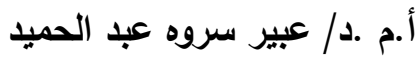

أثز أستخدام استراتيجية التعلم التعاونى

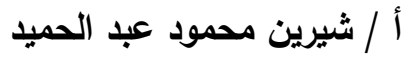

* صدق بطاقة الملاحظة: مدة

- للتحقق من كفاءة بطاقة الملاحظة تم عرضـها على مجموعة من المحكمين في (التربية النوعية ورياض الأطفال)، وقد طلب منهم الإدلاء بآرائهم من حيث: وضوح ومناسبة تعليمات البطاقـة ، وقدرة مفردات البطاقـة على قيـاس المهارة ، وصـحة ودقـة المفردات مـن الناحيـة اللغوية ، واقتراح ما يرونه من تعديلات في بنود البطاقة أو بالنسبة للبطاقة ككل ومن خلال

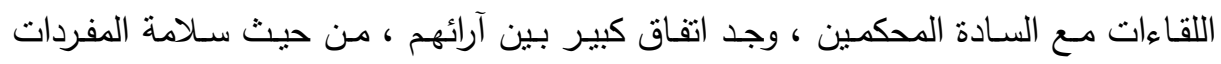
ودقتها، وكذلك قدرة اتفاق البطاقة على قياس المهارة ، ومناسبة الألفاظ ووضوحها بعد إجراء بعض من التعديلات المقترحة ، لتصبح البطاقة صالحة للاستخدام.

معامل ثبات ألفا كرو نباخ: - مبات

تـم حسـاب الثبـات بواسـطة معادلـة ألفـا كرو نبـاخ، وبلغت قيمـة معامـل الثبـات لبطاقـة الملاحظة ككل (9 9019,)، بينما بلغت قيمة معامل الثبات للمحور الأول مهارة التلوين (T79 ^ر,)

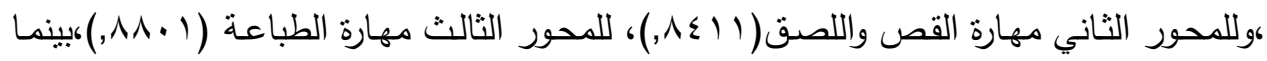
بلغ مجموع المحاور ككل (7 7 (1), وهي تدل علي درجة جيدة من الثبات لبطاقة الملاحظة مما يطمئن علي استخدامها كأداة للقياس. هـ - تعديل البطاقة وفقاً لنتائج التحكيم:

قد أجريت التعديلات على بطاقة الملاحظة بناءاً على آراء المحكمين والتي تمثلت فيما يلي:

- تعديل صياغة بعض بنود بطاقة الملاحظة لتصبح أكثر وضوحا. - حذف بعض الخطوات الإجرائية للمهارة الفرعية لعدم أهميتها.

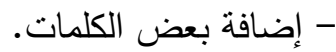

حيث أقروا بنسبة (ه9\%) على كل ما جاء بها من مهارات وبذلك تحققت الباحثة من الصدق لبطاقة الملاحظة. 
- ثبات بطاقة ملاحظة الأداء: - مل

وقد نم الأستعانة بأحد الزملاء في تخصص رياض الأطفال، وتم تدريبها على استخدام

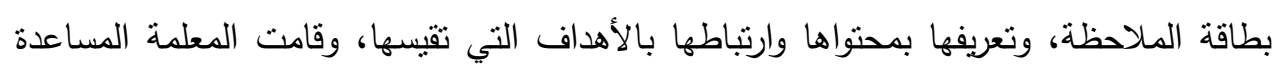
(معلمة رياض الأطفال) بملاحظة أداء الأطفال.

ـ - إعداد البرنامج و البرنامج مقسم لثثلاث أنثطة :

النشاط الأول: (مهارة التلوين) وتتضمن أريع لقاءات :

- اللقاء الأول : التعارف بين الباحثة والأطفال - اللقاء الثانى: الألوان الأساسية. - اللقاء الثالث : تلوين دائرة الألوان - اللقاء الرابع: تلوين صور واشكال هندسية وعضوية. النشاط الثانى (مهارة القص واللصق) وتتضمن ثلاث لقاءات: - اللقاء الاول: جمع صور لأشكال هندسية، طيور، حيوانات، فواكه، خضروات. - اللقاء الثانى: قص أثنكال ثم لصقها فى المكان المحدد لها. - اللقاء الثالث: عمل ألبوم يضم العناصر المتشابهه. النشاط الثالث (مهارة الطباعة) وتتضمن أريع لقاءات: - اللقاء الاول: الطباعة (مفهمومها - انواعها - خاماتها) - اللقاء الثانى: الطباعة بالاستتسل. - اللقاء الثالث: الطباعة باستخدام ورق الثجر والايدى. - اللقاء الرابع: عمل مفرش من الطباعة وغلاف لقصة. تم إعداد برنامج فى ضوء ما ورد بالأطار النظرى وفيما يلى إجراءات إعداد

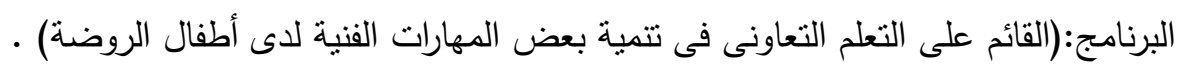


أ.د/ ماجدة هاشم بخيت

أ.م .د/ عبيز سروه عبد هائدم الحميد

أثز أستخدام استراتيجية التعلم التعاونى

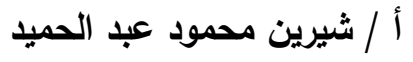

أولا : الأهداف العامة للبرنامج :

1- تتمية المهارات الفنية (التلوين - القص واللصق - الطباعة ) لأطفال الروضة .

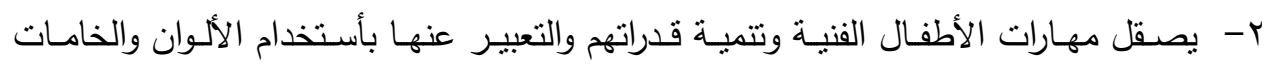
المختلفة.

r- تتمية روح المشاركة والتعاون من خلال ممارسة بعض الأنشطة الفنية والتي تؤدي إلي تقوية الترابط بين الأطفال ونمو العلاقات الأجنماعية ونقوينها.

ع - مساعدة الأطفال علي تتمية إمكانياته الفطرية حيث يتكيف ويتفاعل مع بيتئة .

0- إنراك الأطفال في الأنشطة الفنية وإكسابهم المهارات الفنية المختلفة والعمل علي استمراريتها.

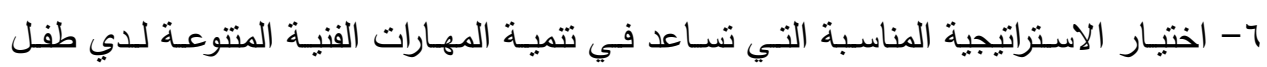
الروضة.

- - - - رعاية الأطفال وتتمية مهاراتهم الفنية المختلفة. ^- يتعرف علي المهارات الفنية المختلفة. 9- الكثفف عن القيم الجمالية في المهارات الفنية المختلفة. • إ- العمل على توفير بيئة مناسبة لندريب أطفال الروضة. 11- إعداد طفل قادر على اكتساب المهارات الفنية المختلفة. r ا - القدرة على التواصل بفاعلية مع الآخرين • با - القدرة علي تطوير العمل الفني. ثانيا :الأهداف الإجرائية للبرنامج : استمدت الباحثة الأهداف الإجرائية للبرنامج فيما يلي:

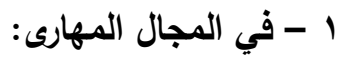
في نهاية النشاط يجب أن يكون كل طفل قادرا علي أن: 1- ينجز الطفل المهام المطلوبة منه . r- بيتعاون الطفل مع زملائه لأتمام المهارات المطلوبة منه . r- بيتواصل الطفل مع زملائه فى الأنشطة . 
ـ- يتحكم باللون داخل المساحة .

○- يختار اللون المناسب للشكل .

צ- يسنطيع عمل غلاف قصة من صنع يده .

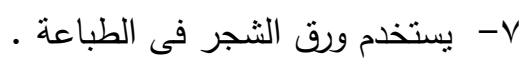

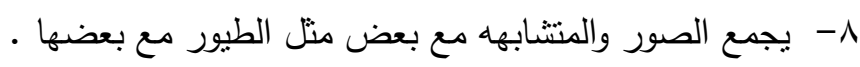

9- - يسنطيع قص و لصق شكل بمفرده .

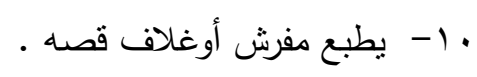

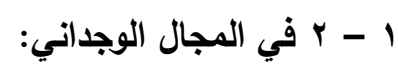

في نهاية النشاط يجب أن يكون كل طفل قادرا على أن:

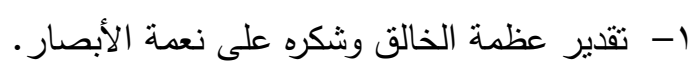

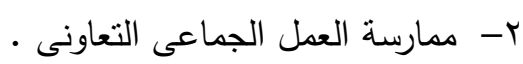

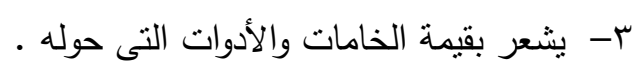

ع- بيتثر أوقات الفراغ فى أعمال مفيدة .

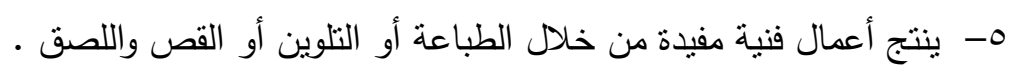
ז- يحترم آراء الآخرين من خلال المشاركة في أعمال فنبة وجمالية.

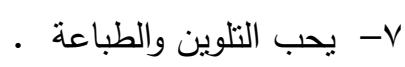

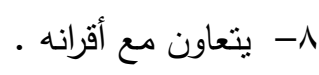

ثالثاً: استراتيجيات التعلم المتبعة في البرنامج:

هي خطة عامة يضع من خلالها المعلم تصوراً لاجراءاتة وممارساته التدريسية المختلفة

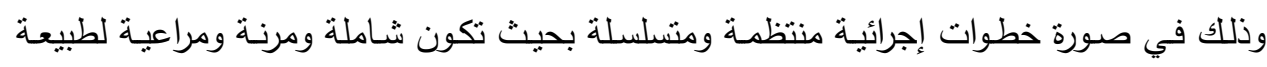
الطفل وتمثل الواقع الفعلي لما يحدث خلال الموقف التدريسي للوصول إلى الأهداف المرجوة.

كما تعرف بأنها " تخطيط ينظم مجموعة من الأفكار والمبادئ في إطار عام منكامل مرنبط

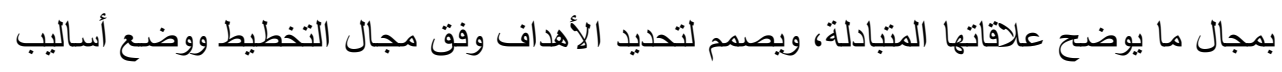

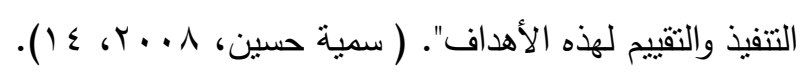
واعتمدت على استراتيجية التعلم التعاوني ( استراتيجية التعلم معا ). 
رابعا : خطوات إعداد البرنامج :

أ - اختيار المادة العلمية :

و روعى عند اختيار المادة العلمية ما يلي:

• أن تكون مناسبة لطفل الروضة (مجموعة الدراسة).

ه أن تكون مرتبطة بالمنهج الدراسي وتتفق وطبيعة المرحلة العمرية.

• أن تكون محدده بدقه وتتتاسب مع استراتيجيات التدريس المقترحة والتي تساعد على تتميه

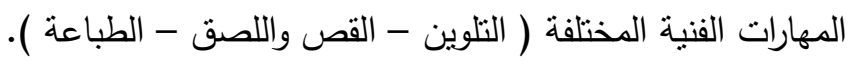

وقد جمعت المـادة العلميـة المرتبطة بالبرنـامج التعليمي مـن المراجع والبحـوث والدراسـات

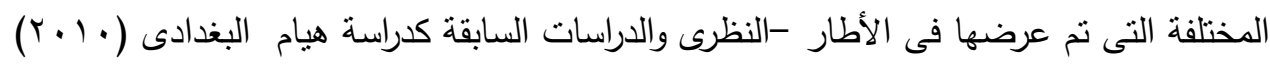
، و دراسة زنيب محمود (T) ( • (r).

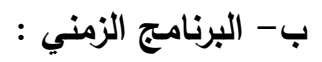

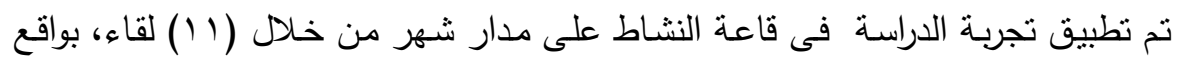

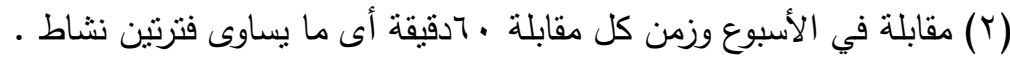

\section{0- إعداد دليل معلمة الروضة:}

\section{مقدمه}

تعد مرحلة رياض الأطفال من أهم المراحل التى يكتسب فيها الطفل المفاهيم والمهارات

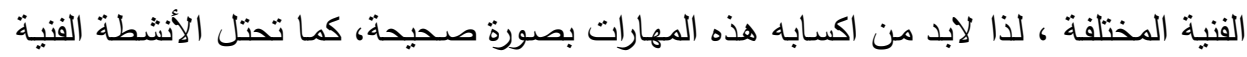

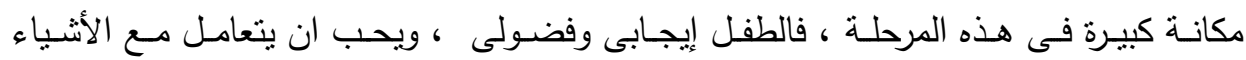

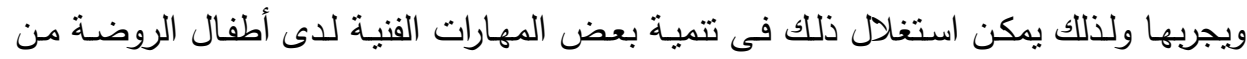

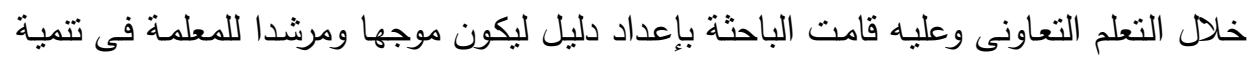

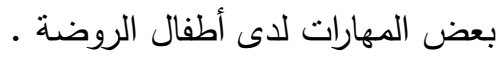

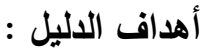
ا - أن يكون موجها ومرشدا للمعمة . r- أن يمثل خطة سير تتبعها المعلمة فى تقديم الأنشطة الفنية للأطفال . r- أن يساعد المعلمة على تتمية بعض المهارات الفنية لاى أطفال الروضة . 
أهمية الاليل : n

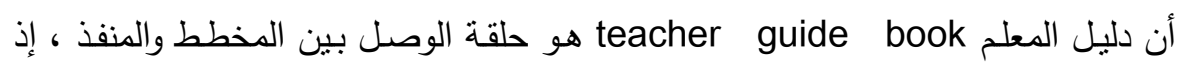

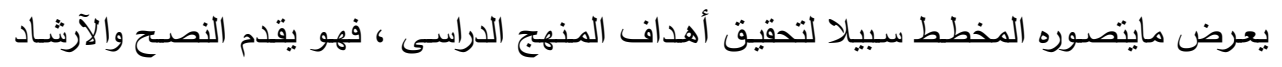

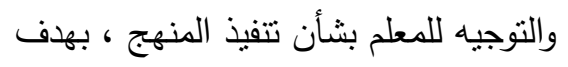

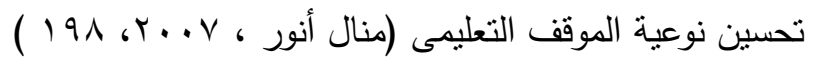

$$
\begin{aligned}
& \text { ويفيد دليل المهارات الفنية معلمة رياض الأطفال فى الآتى : }
\end{aligned}
$$$$
\text { 1 - تحديد المهارات الفنية المناسبة لطفل الروضة . }
$$

ץ- تحديد الطريقة التى يجب أن تتبعها المعلمة والأنشطة التى يجب أن يقوم بها الأطفال

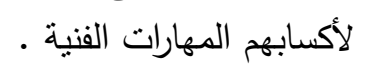

r- مساعدة المعلمة على إكساب أطفال الروضة بعض المهارات الفنية المناسبة لهم •

ع - يقدم الدليل المعلومات اللزمة عن نوعية الأنشطة التى تتاسب طفل الروضة .

0- يسهم الدليل فى تهيئة الأطفال للمرحلة التعليمية التالية وحبهم للأنشطة الفنية .

\section{مقترحات للإفادة من الاليل :}

1- يفل أن تلقة المعلمة نظرة عامة على الاليل ككل فى البداية وتتعرف على محتوياته . ץ- - يفضل أن تقوم المعلمـة بقراءة الأطسار النظرى للدليل وتتعرف على المهارات الفنيـة المراد تتميتها عند طفل الروضة .

r- تترك المعلمة الحرية الكافية للأطفال للقيام بالأنشطة الفنية المختلفة . ع- - بعد عرض كل مهارة فنية وأنشطتها الفنية تقوم المعلمة بعملية تقويم حتى تتعرف على ما

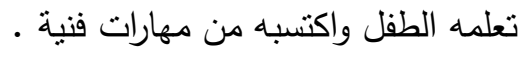

نتائج الاراسة وتفسيرها :

$$
\text { وللتحقق من صحة الفرض الأول والذي ينص على : }
$$

1 - يوجد فرق ذو دلالة إحصائية بين منتسطي درجات المجموعة التجريبية في التطبيقين القبلي

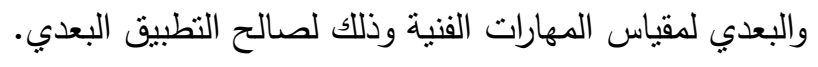

تم حسـاب الفرق بين استجابات العينـة التجريبيـة لمقياس المهارات الفنيـة في الاختبارين القبلـي والبعـى ودرجـة الكسـب ونسـبة التحسـن باسـتخدام اختبـار النسبة (ز) والجـداول التاليـة توضح ذللك : 
أ. أد/ ماجدة هاشم بخيت

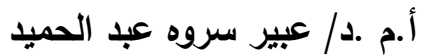

أثر أستخدام استراتيجية التعلم التعاونى

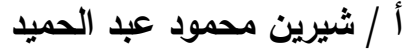

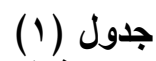

مقياس المهارات القنية للعينة التجريبية في التطبيث القبلى حيث (ن= ـ ع)

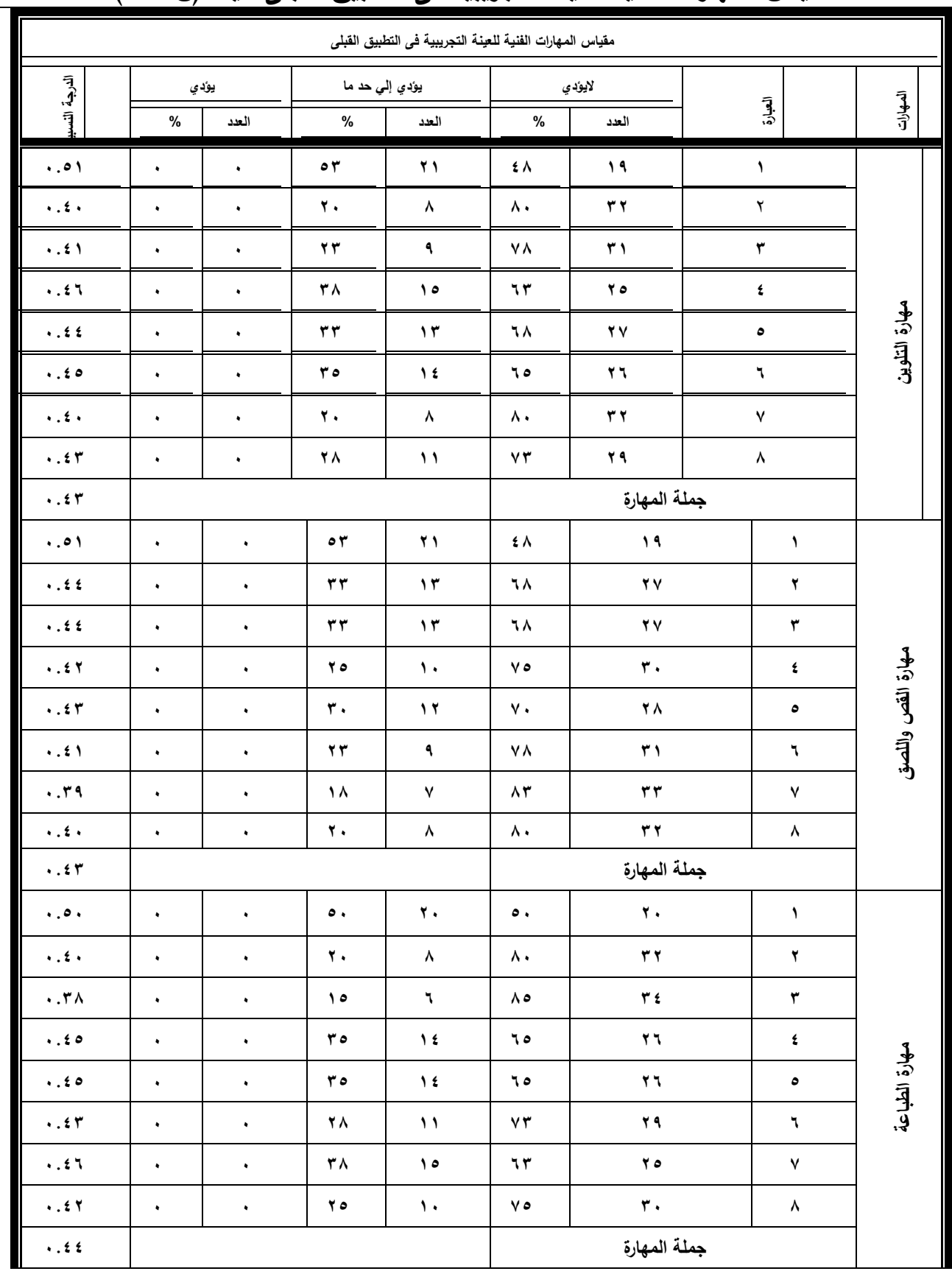


المجلة العلمية لكلية رياض الاطفال - جامعة اسيوط

\begin{tabular}{|c|c|c|c|c|c|c|c|c|c|}
\hline \multicolumn{10}{|c|}{ مقياس المهارات الفنية للعينة التجريبية فى التطبيق القبلى } \\
\hline \multirow{2}{*}{ 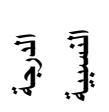 } & \multicolumn{2}{|c|}{ يؤدي } & \multicolumn{2}{|c|}{ 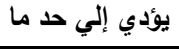 } & \multicolumn{2}{|c|}{ 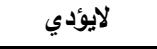 } & \multirow{2}{*}{\multicolumn{2}{|c|}{ 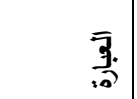 }} & \multirow{2}{*}{$\begin{array}{l}\overline{\bar{z}} \\
\overline{3}\end{array}$} \\
\hline & $\%$ & 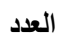 & $\%$ & 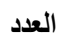 & $\%$ & 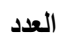 & & & \\
\hline & & & & & & & $\cdots \mathrm{TV}$ & \multicolumn{2}{|c|}{ المتوسط المرجح } \\
\hline & & & & & & & $\cdots v$ & \multicolumn{2}{|c|}{ الخطا المعيارى } \\
\hline & & & & & & &.$A r$ & \multicolumn{2}{|c|}{ الحد الاعلى للثقة } \\
\hline & & & & & & &. .04 & \multicolumn{2}{|c|}{ الحد الادنى للثقة } \\
\hline
\end{tabular}

ويتضح من الجدول ( () والثكل البيانى رقم (1) انخفاض منوسط درجات الأطفال في

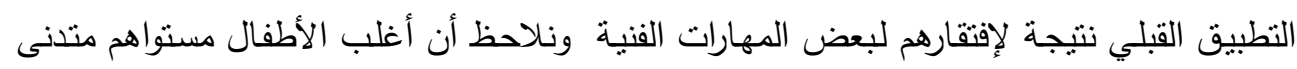

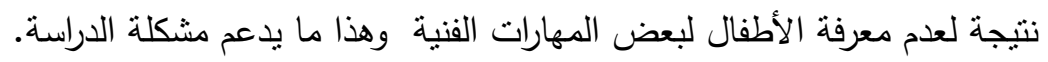

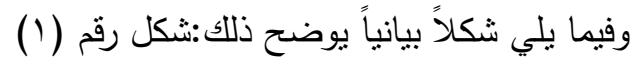

متوسطات درجات الأطفال مجموعة الدراسة فى التطبيق القبلى لمقياس المهارات الفنية:

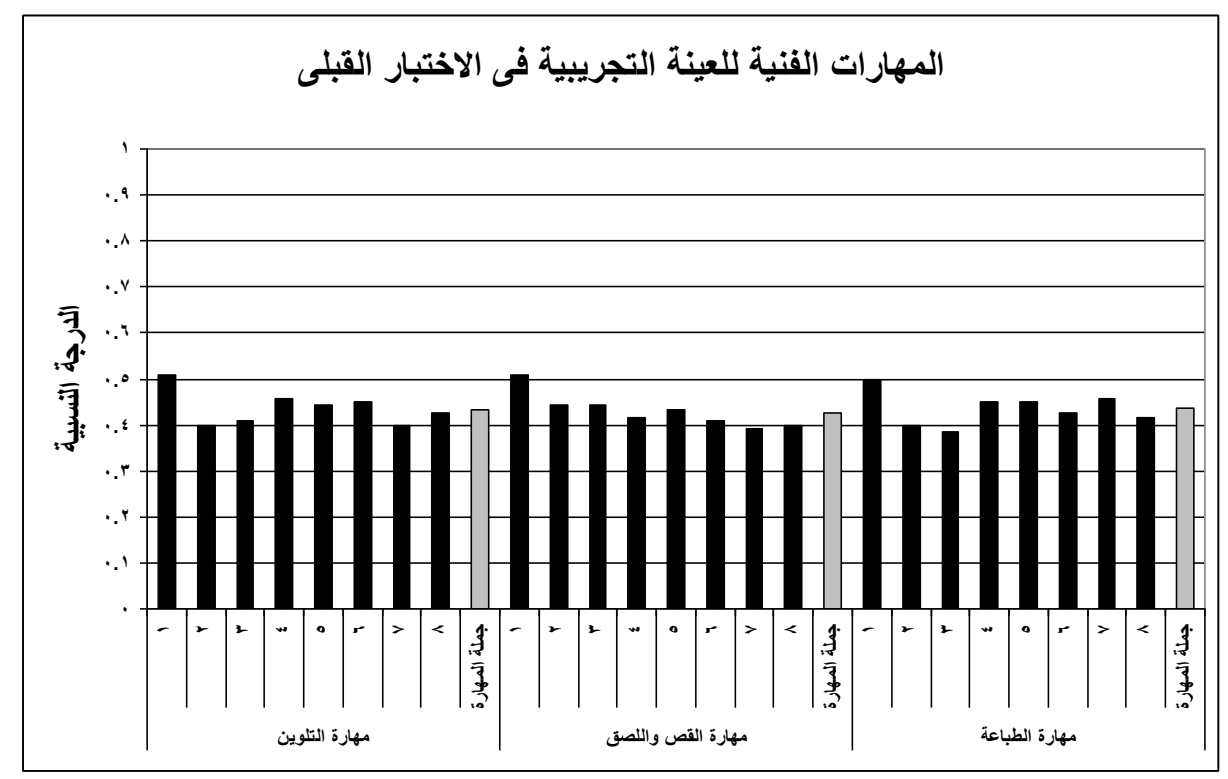

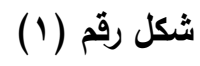

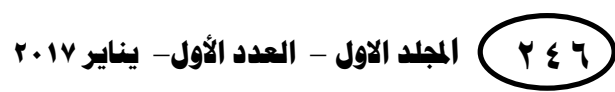


أ.د / ماجدة هاشم بخيت

أ.م .د/ عبيز سروه عبد هائد الحميد

أثر أستخدام استراتيجية التعلم التعاونى

أ / شيرين محمود عبد الحميا عبل الحميل

جدول (r)

مقياس المهارات الفنية للعينة التجريبية في التطبيق البعدى حيث (ن= • ؛)

\begin{tabular}{|c|c|c|c|c|c|c|c|c|}
\hline \multicolumn{9}{|c|}{ مقياس المهارات الفنية للعينة التجريبية فى التطبيق البعدى } \\
\hline \multirow{2}{*}{ 甬雨 } & \multicolumn{2}{|c|}{ 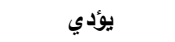 } & \multicolumn{2}{|c|}{ يؤدي إلي حـ ما } & \multicolumn{2}{|r|}{ لايؤدي } & \multirow{2}{*}{ 里 } & \multirow{2}{*}{$\frac{\bar{s}}{\overline{3}}$} \\
\hline & $\%$ & 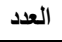 & $\%$ & 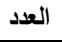 & $\%$ & 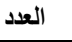 & & \\
\hline .991 & $\vee \wedge$ & $\mu_{1}$ & 11 & $\checkmark$ & • & r & 1 & \multirow{9}{*}{ 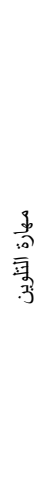 } \\
\hline$\cdot .19$ & 71 & rV & r & ir & • & - & r & \\
\hline$\cdot . \wedge \wedge$ & 70 & r & r & ir & r.o & 1 & $r$ & \\
\hline. $.7 r$ & $r \cdot$ & $\wedge$ & ¿0 & 11 & ro & $1 \varepsilon$ & $\varepsilon$ & \\
\hline$\cdot . \wedge 1$ & «o & 11 & or & r) & r.० & 1 & 0 & \\
\hline .99 & $\wedge \wedge$ & ro & Ir & 0 & · & · & 7 & \\
\hline אז.. & $r$. & $\wedge$ & 0 . & $r$. & $r$. & ir & v & \\
\hline.$\vee \wedge$ & ro & $1 \varepsilon$ & 70 & צ & . & . & $\wedge$ & \\
\hline$\cdot . \wedge \varepsilon$ & & & & & \multicolumn{3}{|c|}{ جملة المهارة } & \\
\hline$\cdot . \wedge V$ & Tr & ro & ro & $1 \varepsilon$ & r.o & 1 & 1 & \multirow{9}{*}{ 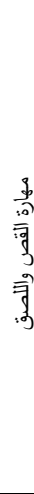 } \\
\hline$\therefore 9$. & v. & rA & r. & ir & . & . & r & \\
\hline $.9 r$ & vo & $r$. & ro & 1. & . & . & $r$ & \\
\hline.$\cdot v 1$ & $r \wedge$ & 11 & 01 & r & 10 & 7 & $\varepsilon$ & \\
\hline. .19 & 71 & TV & Tr & ir & · & · & 0 & \\
\hline .94 & vo & $r$. & ro & 1. & · & · & 7 & \\
\hline .94 & $\vee \wedge$ & r & r & 9 & · & · & v & \\
\hline .94 & vo & $r$. & ro & 1. & · & · & $\wedge$ & \\
\hline-991 & & & & & \multicolumn{3}{|c|}{ جملة المهارة } & \\
\hline. .10 & 7. & $r \leq$ & ro & $1 \varepsilon$ & 0 & $r$ & 1 & \multirow{9}{*}{ 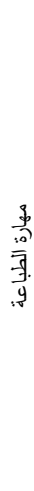 } \\
\hline. .19 & 71 & TV & r & ir & . & · & r & \\
\hline-991 & vo & $r$. & r & 9 & r.o & 1 & $r$ & \\
\hline$\cdot . \wedge \wedge$ & שז & ro & rs & 10 & $\cdot$ & · & $\varepsilon$ & \\
\hline.$\wedge r$ & 0. & $r$. & o. & $r$. & · & · & 0 & \\
\hline. .01 & $r$. & $\wedge$ & ro & $1 \leq$ & $\leq 0$ & 11 & 1 & \\
\hline. .19 & 71 & TV & r & $1 T$ & · & · & v & \\
\hline .91 & vr & $r q$ & rA & 11 & . & · & $\wedge$ & \\
\hline$\cdot . \wedge \wedge$ & & & & & & جملة المـ & & \\
\hline
\end{tabular}


المجلة العلمية لكلية رياض الاطفال - جامعة اسيوط

\begin{tabular}{|c|c|c|c|c|c|c|c|c|}
\hline \multicolumn{9}{|c|}{ مقياس المهارات الفنية للعينة التجريبية فى التطبيق القبلى } \\
\hline \multirow{2}{*}{ 零雪 } & \multicolumn{2}{|c|}{ 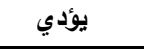 } & \multicolumn{2}{|c|}{ يؤدي إلي حد ما } & \multicolumn{2}{|c|}{ لايؤدي } & \multirow{2}{*}{ 承 } & \multirow{2}{*}{ 矛 } \\
\hline & $\%$ & 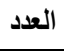 & $\%$ & العدد & $\%$ & العدد & & \\
\hline & & & & & & & . . TV & \\
\hline & & & & & & & $\cdots v$ & \\
\hline & & & & & & & . . & \\
\hline & & & & & & & . or & \\
\hline
\end{tabular}

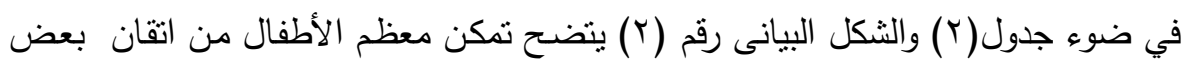

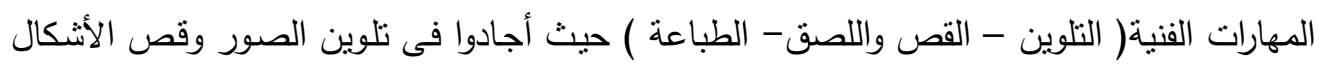

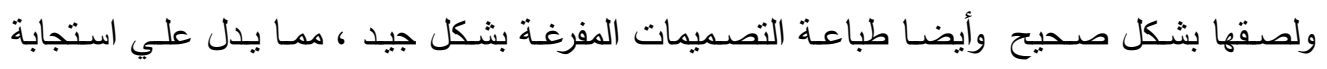

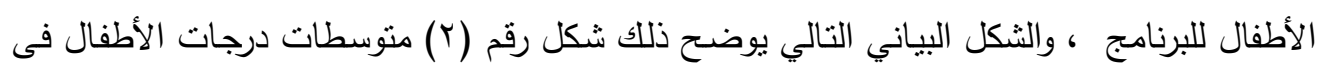
النطبيق البعدى لمقياس المهارات الفنية : الإنيان

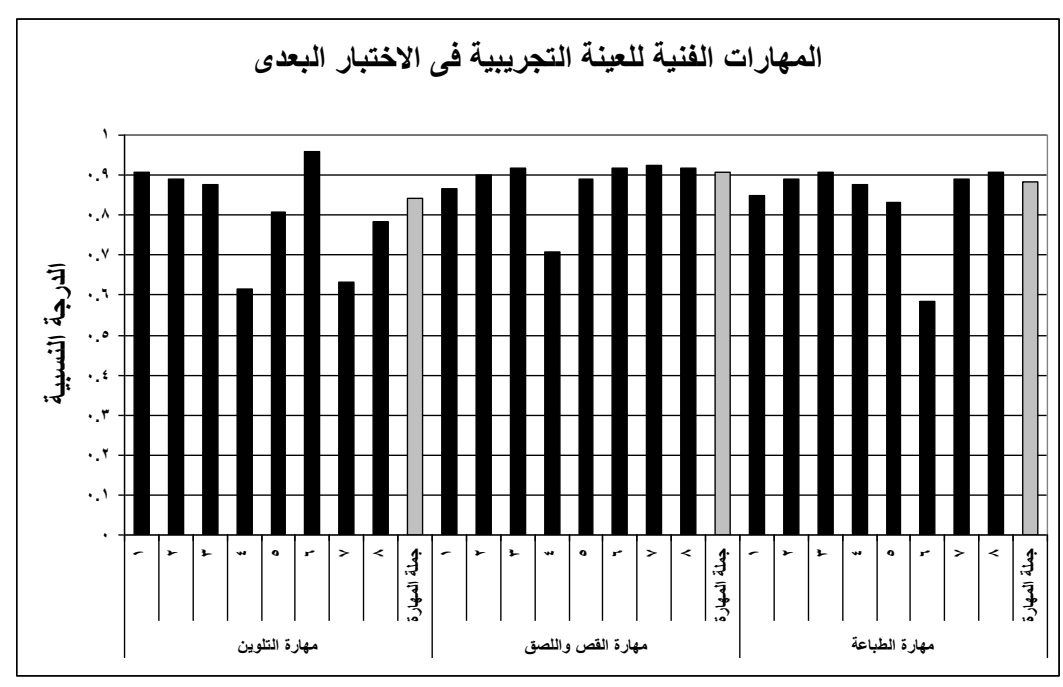

شكل رقم (ץ) 
أ أد/ ماجدة هاشم بخيت

أ.م .د/ عبيز سروه عبد الحمبد بديد

أثر أستخدام استراتيجية التعلم التعاونى

أ / شيرين محمود عبد الحميد عيد الحميد

جدول (r)

الفررق فى المهارات الفنية للعينة التجريبية بين التطبيق القبلى والبعدى حيث (ن= • ع)

\begin{tabular}{|c|c|c|c|c|c|c|c|c|}
\hline \multicolumn{9}{|c|}{ الفرق فى المهارات الفنية للعينة التجريبية بين التطبيق القبلى والبعدى } \\
\hline \multirow{2}{*}{ التحسن \% } & \multirow{2}{*}{ 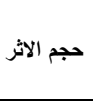 } & \multirow{2}{*}{ معدل الكسب } & \multicolumn{2}{|c|}{ 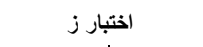 } & \multicolumn{2}{|c|}{ الدرجة النسبية الدبية } & \multirow{2}{*}{ 匀 } & \multirow{2}{*}{$\frac{\bar{s}}{\overline{3}}$} \\
\hline & & & 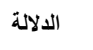 & قيمةز & 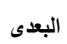 & 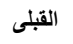 & & \\
\hline$\vee \wedge .79$ & $0 . v 1$ & $1 . r_{1}$ &., .0 & r.r. & .91 &. .01 & 1 & \multirow{9}{*}{$\begin{array}{l}3 \\
3 \\
3 \\
3 \\
3\end{array}$} \\
\hline Irt.ar & $V . \cdot r$ & $1 . r 1$ &., .1 & r.^I & $\cdot . \wedge 9$ & $\cdot \varepsilon$ & r & \\
\hline $11 \leq .79$ & $9.7 \mathrm{~V}$ & $1 . Y^{4}$ & $\cdot, \cdot 1$ & r.74 & $\cdot . \wedge \wedge$ & $\cdots \leqslant 1$ & $r$ & \\
\hline$r \leqslant .00$ & r.YT & $\cdots \leqslant 0$ & ع د & $\because 9$. & 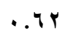 & 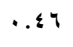 & $\varepsilon$ & \\
\hline$\Lambda r . . r$ & $0 . r \leq$ & $1 . . r$ &., .0 & r.. q & $\cdot .11$ & 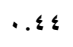 & 0 & \\
\hline 114.97 & V.rY & $1 . \varepsilon r$ & $\cdot,+1$ & Y.qY & .99 & $\cdots \leqslant 0$ & 7 & \\
\hline OA.rT & T.rT & r & غ د & I.rr & r. & $\rightarrow \varepsilon$ & v & \\
\hline A $\leq . M$ & $0.1 r$ & .911 &., .0 & r... $\varepsilon$ & $\because \vee \wedge$ & 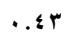 & $\wedge$ & \\
\hline Qะ.YT & $0 . \wedge r$ & $1.1 \%$ & $\cdot, \cdot 1$ & r.rT & $\cdot \wedge \varepsilon$ & 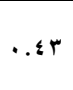 & جملة & \\
\hline$v \cdot . \leqslant q$ & 0.14 & $1 . .9$ &., .0 & Y.. $q$ & $\cdot . \wedge \vee$ & .01 & 1 & \multirow{9}{*}{ 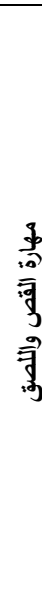 } \\
\hline I.r.vV & 9.00 & $1 . r \wedge$ & $\cdot, \cdot 1$ & T.Tr & $\because 9$. & 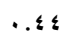 & $r$ & \\
\hline $1 \cdot v .00$ & $7 . \vee 9$ & r.r &., 1 & r.Vr & .94 & . & $r$ & \\
\hline$v \ldots$ & $\{.1 V$ &.$\vee \vee q$ & غ & 1.70 &.$v 1$ & ..$\leqslant r$ & $\varepsilon$ & \\
\hline $1.0 . v V$ & 7.00 & I.rV & $\cdot, \cdot 1$ & r.Tr & $\cdot . \wedge 9$ & - & 0 & \\
\hline $\mid r \leq . \leq q$ & V.rY & 1.rv & $\cdot, \cdot 1$ & Y.91 & .94 & . \&1 & 9 & \\
\hline Irצ.IV & V.TY & $1 . \leqslant 1$ & $\cdot,+1$ & r... & ra &.$r q$ & v & \\
\hline 1 Ir..1V & V.rی & $1 . r \Lambda$ & $\cdot, .1$ & 9.90 & .94 & $\cdots \varepsilon$ & $\wedge$ & \\
\hline Mr.vr & 7.9. & I.rr & $\cdot, \cdot 1$ & r.VV & .91 & 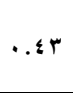 & جملة & \\
\hline$v \ldots$ & o... & $1 . .0$ &., .0 & r... & $\cdot . \wedge 0$ & $\cdots 0$ & 1 & \multirow{5}{*}{ 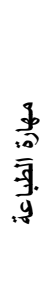 } \\
\hline IrY.qr & $v . . r$ & $1 . r 1$ &., .0 & Y.AI &.$\wedge 9$ & $\cdots \varepsilon$. & $r$ & \\
\hline 174.97 & V.o. & $1 . r \Lambda$ &., .0 & r... & .91 &.$r \Lambda$ & $r$ & \\
\hline $9 \leq . \leq \leq$ & $7 . . V$ & I.r. &., .0 & $r . \varepsilon r$ & $\cdot . \wedge \wedge$ & $\therefore \leqslant 0$ & $\varepsilon$ & \\
\hline 10.19 & $0 . \leqslant \wedge$ & $1 . .1$ & $\cdot, .0$ & r.19 & $\cdot . \wedge r$ & $\cdot . \leqslant 0$ & 0 & \\
\hline
\end{tabular}




\section{المجلة العلمية لكلية رياض الاطفال - جامعة اسيوط}

\begin{tabular}{|c|c|c|c|c|c|c|c|c|}
\hline \multicolumn{9}{|c|}{ لفرق فى المهارات الفنية للعينة التجريبية بين التطبيق القبلى والبعدى } \\
\hline \multirow{2}{*}{ التحسن \% } & \multirow{2}{*}{ 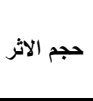 } & \multirow{2}{*}{ معدل الكسب } & \multicolumn{2}{|c|}{ 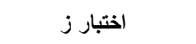 } & \multicolumn{2}{|c|}{ 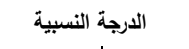 } & \multirow{2}{*}{ 里 } & \multirow{2}{*}{$\begin{array}{l}\bar{s} \\
\bar{i}\end{array}$} \\
\hline & & & 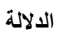 & 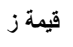 & 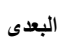 & 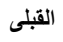 & & \\
\hline rv.ro & Y.YY & 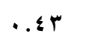 & $\dot{~}$ & $\because 9$ &. .01 & 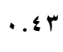 & 7 & \\
\hline $9 \leq .00$ & 7.19 & 1.rr & $\cdot, .$, & r. $ڤ \Lambda$ &. .19 & $\cdot . \leqslant 4$ & $v$ & \\
\hline $111 .$. & V..r & 1.rr & $\cdot,+1$ & r.^I & .99 & 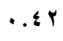 & $\wedge$ & \\
\hline $1 \cdot 1.9$. & 7.rv & $1 . r \leq$ & $\cdot,+1$ & r.०० &..$\wedge \Lambda$ & $\therefore \leqslant$ & جملة المهارة & \\
\hline & & & & & \multicolumn{2}{|c|}{. $.7 \mathrm{~V}$} & \multicolumn{2}{|c|}{ المتوسط المرجح } \\
\hline & & & & & \multicolumn{2}{|c|}{$\cdots v$} & \multicolumn{2}{|c|}{ 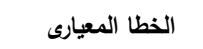 } \\
\hline & & & & & \multicolumn{2}{|c|}{$\cdot . \wedge r$} & \multicolumn{2}{|c|}{ الحد الاعلى للثقة } \\
\hline & & & & & \multicolumn{2}{|c|}{$.0 Y$} & \multicolumn{2}{|c|}{ الحد الادنى للثقة } \\
\hline
\end{tabular}

يتضح من جدول (ץ) والثكل رقم (ץ) أن هناك تحسن ملحوظ في إداء الأطفال للمهارات الفنية التي اشتمل عليها مقياس المهارات بالنسبة لمهارة التلوين والتي تضمنت عدد من المهارات

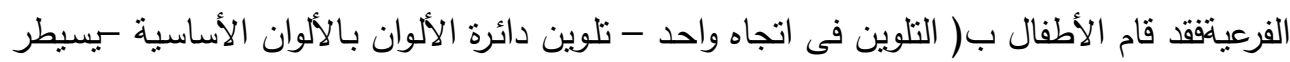
على الثكل كامل )وبالنسبة لمهارة القص واللصق ( جمع صور وعناصر متنثابهه- نم قص الثنكل بصورة صحيحة ـصق الثكل فى المكان المحدد - توظيف الثكل وعمل ألبوم ) أما بالنسبة لمهارة الطباعة ( تنكن الأطفال من الطباعة بإستخدام ورق الثجر - ومن استخدام التصميمات المفرغة

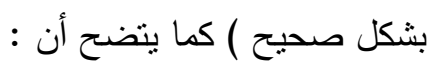
1- نوجد فروق ذات دلالة إحصائية عند مستوى ( ( , •) بين منوسطى درجات مجموعة الدراسة

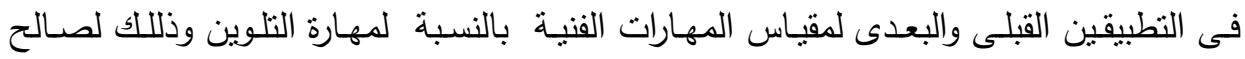

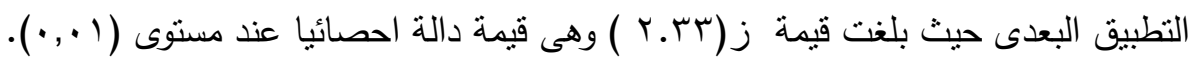
وفى المهارات الفرعيـة التاليـة يستخدم الألكوان الأساسية في التلوين قيمـة (ز) تسـاوي

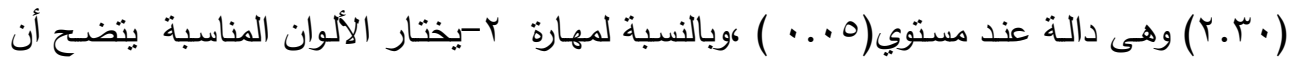

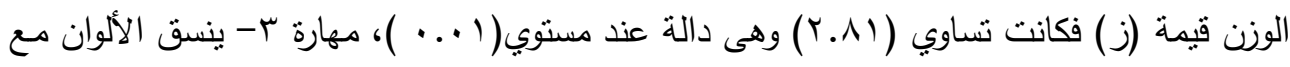

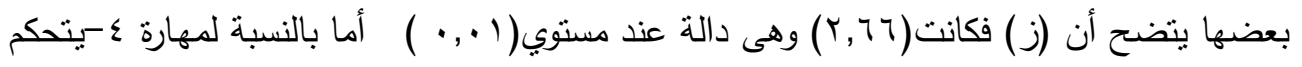

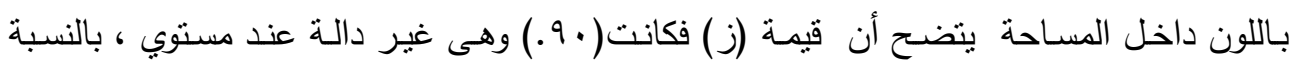

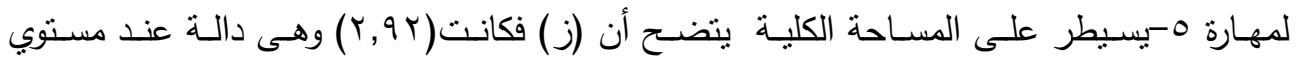




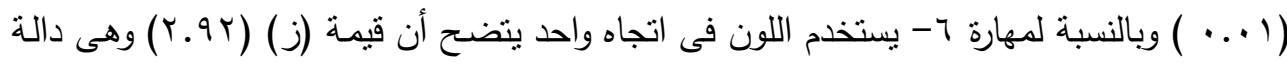

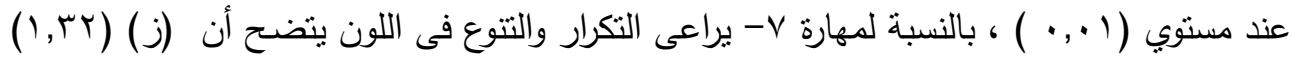

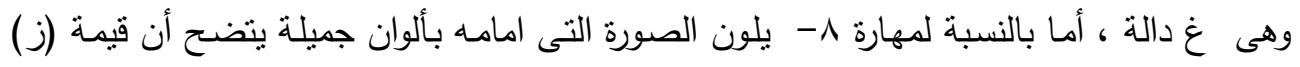

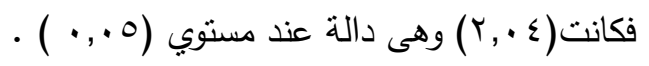

مما يدل على أن البرنامج القائم على استخدام استراتيجية التعلم التعاونى قد أثر في تتمية

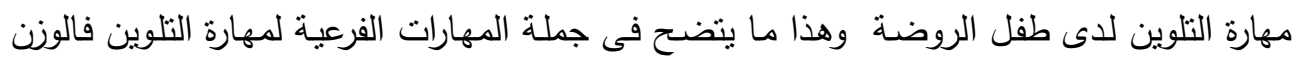

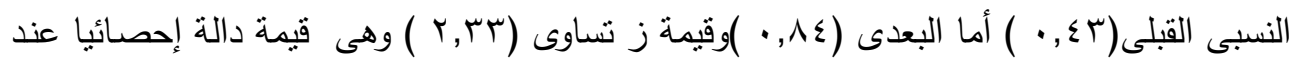
$\cdot(\cdot, \cdot 1)$

أما بالنسبة لمهارة القص واللصق والتي تضمنت عدد من المهارات الفرعية يتضح أن : ץ- توجد فروق ذات دلالة إحصائية عند مستوى ( ( , ·) بين متوسطى درجات مجموعة الدراسة

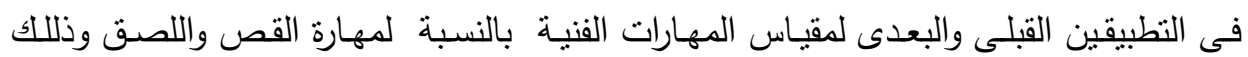

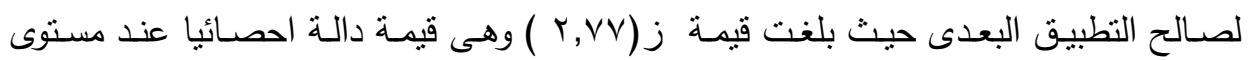

$$
\cdot(\cdot, \cdot 1)
$$

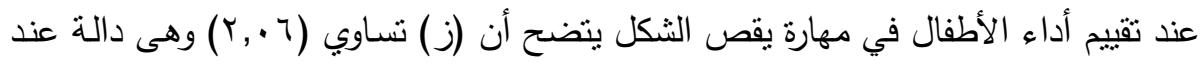

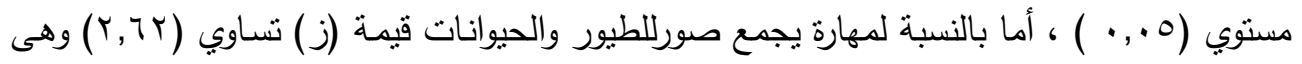

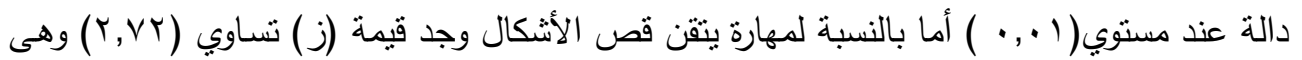

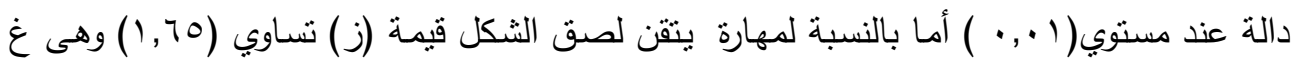

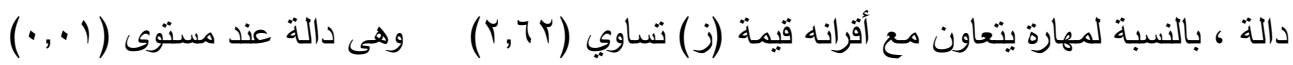

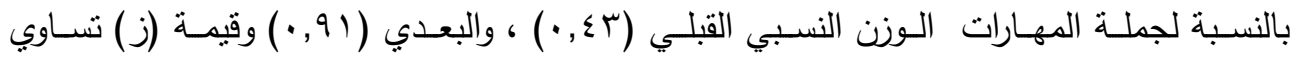
(Y,VY)

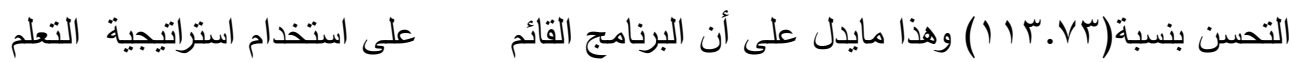

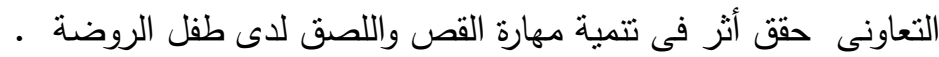
بالنسبة للمهارات الطباعة والتي تضمنت عدد من المهارات الفرعية 
r- توجد فروق ذات دلالة إحصائية عند مستوى ( 1 (, ·) بين منوسطى درجات مجموعة الدراسة

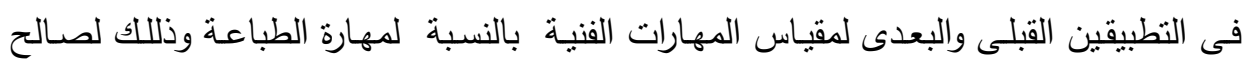
النطبيق البعدى حيث بلغت قيمة ز(Y,00) وهى قيمة دالة احصائيا عند مستوى (1 . , •).

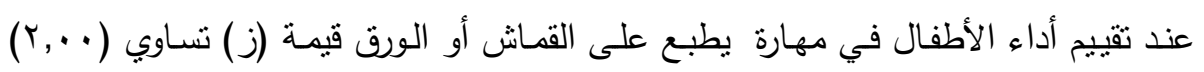

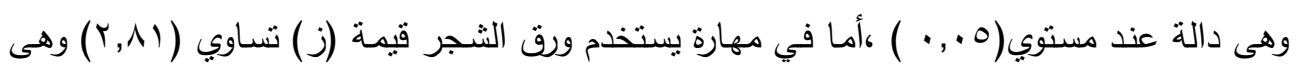

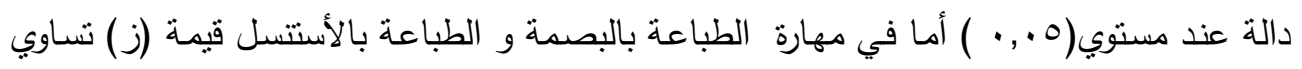

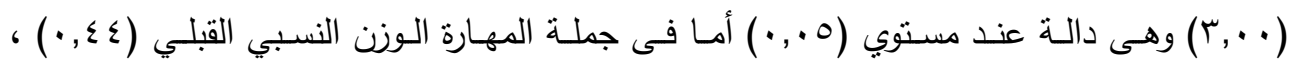

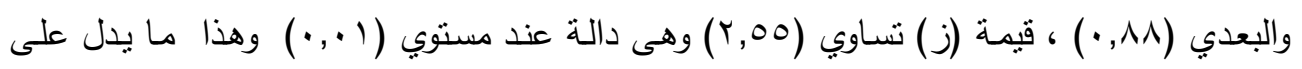

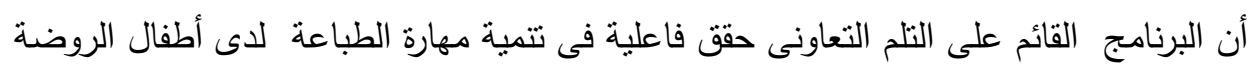
أمابالنسبة للأختبار وأعادة الأختبار فى جملة المهارات لمقياس المهارات نجد قيمة معامل

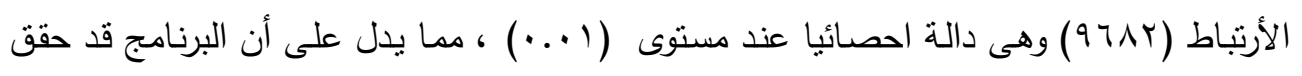

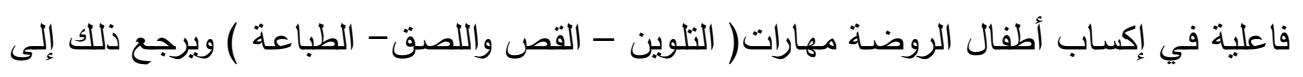

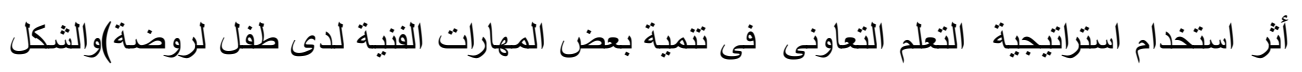
البياني التالي يوضح ذلك:

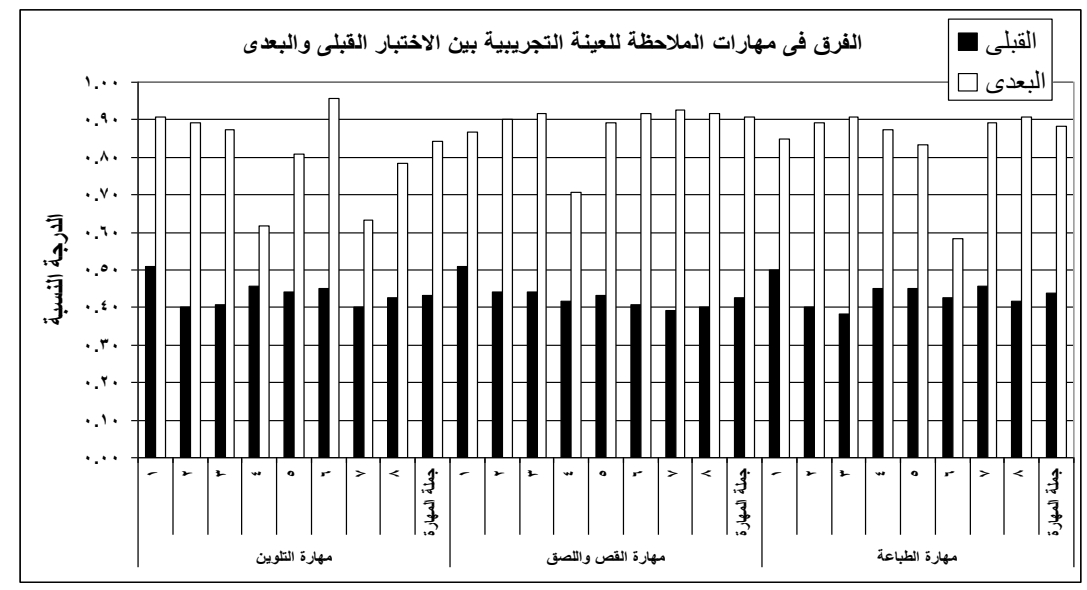

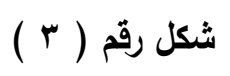

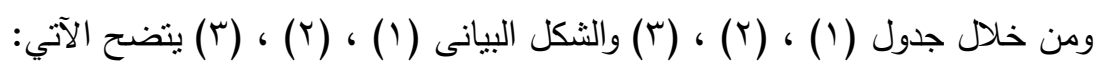


- تمكن معظم الأطفال من تلوينهم للصور التى أمامهم حيث كان التنفيذ جيد ودقيق وذلك نتيجة

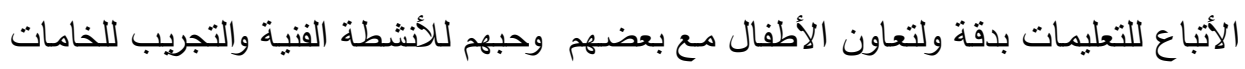

المختلفة.

ثانيا: بالنسبة لمهارة القص واللصق :

- كما ظهر لدي الأطفال دقة في قص الأثكال بصورة صحيحة وذلك نتيجة لتحديد البباحثة

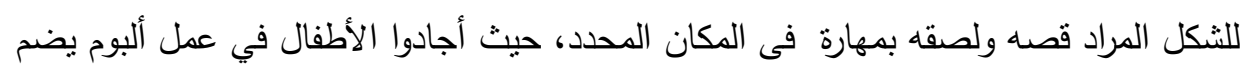
العناصر المتتابهه.

\section{ثالثا : بالنسبة لمهارة الطباعة :}

- حيث تفاعل الأطفال مع الخامة وتعاملوا معها حيث أجادوا الأطفال في الطباعة بورقة الثجر

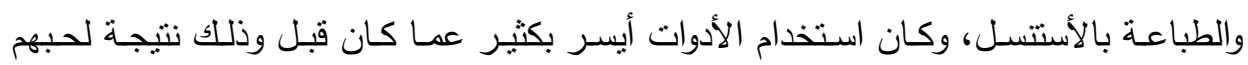
لكأنشطة الفنية والتجريب للخامات المختلفة.

كما تم أنتاج أعمال فنية مفيدة من الطباعة مثل عمل مفرش من صنع يده أوعمل غلاف

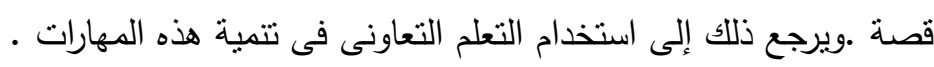
وتتفق نتائج هذه الدراسة مع العديد من الدراسات التي تؤكد علي تتمية المهارات الفنية لطفل

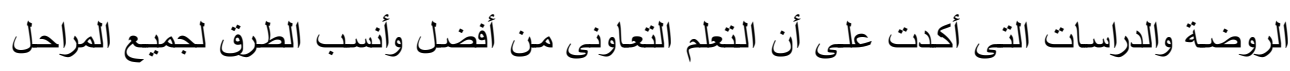

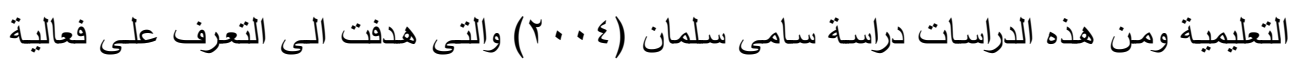

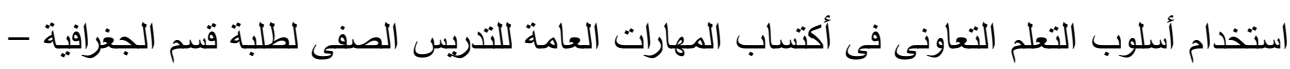

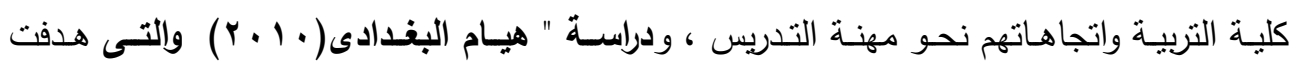

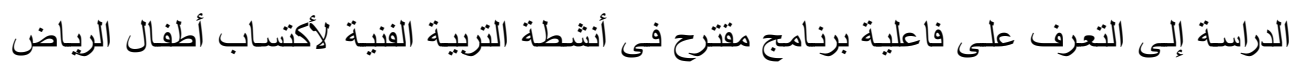

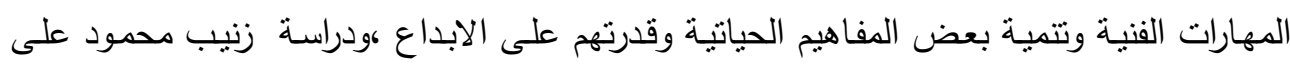

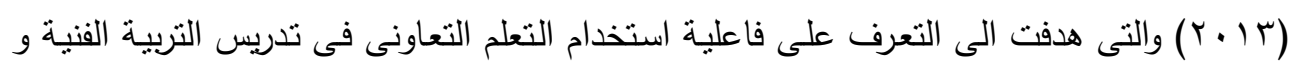

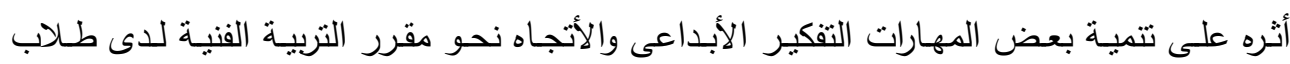

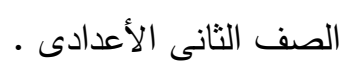


وللتحقق مـن صحة الفرض الثاني مـن الدراسـة والذي ينص على " توجد فروق ذات دلالـة

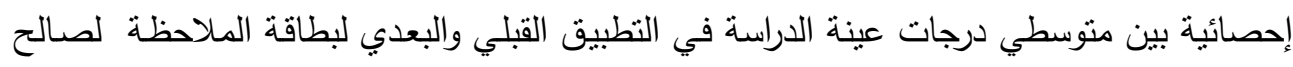

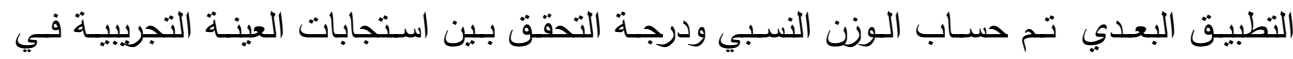

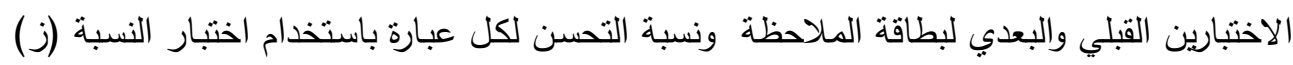

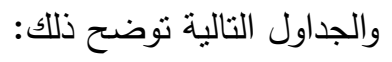

جدول (๕)

الوزن النسبي لبطاقة الملاحظة ودرجة التحقق في التطبيق القبلي للمجموعة التجريبية

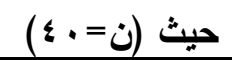

\begin{tabular}{|c|c|c|c|c|c|c|c|c|}
\hline \multicolumn{9}{|c|}{ مهارات الملاحظة للعينة التجريبية فى التطبيق القبلى } \\
\hline \multirow{2}{*}{ 孚 } & \multicolumn{2}{|c|}{ 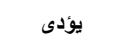 } & \multicolumn{2}{|c|}{ 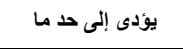 } & \multicolumn{2}{|c|}{ ل الايؤدى } & \multirow{2}{*}{ 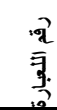 } & \multirow{2}{*}{$\underset{\bar{j}}{\bar{j}}$} \\
\hline & $\%$ & العدد - اد & $\%$ & العدد & $\%$ & العدد & & \\
\hline$\because . \$ 9$ & $\cdot$ & • & $\leqslant \vee .0$ & 19 & 0 r.o & r & 1 & \multirow{17}{*}{$\begin{array}{l}3 \\
: 0 \\
.3 \\
3 \\
3\end{array}$} \\
\hline$\cdot .4$ & $\cdot$ & • & $r v .0$ & 11 & $V Y .0$ & rq & r & \\
\hline$\cdot . \mu$ & $\cdot$ & • & 19.0 & $\bullet$ & $\wedge \vee . \diamond$ & ro & $r$ & \\
\hline$\cdot . r q$ & $\cdot$ & - & $1 V .0$ & v & $\wedge r . \bullet$ & $r r$ & $\varepsilon$ & \\
\hline$\because . r q$ & $\cdot$ & • & 18.0 & 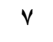 & $\wedge r .0$ & $r r$ & $\bullet$ & \\
\hline$\cdot .4$ & . & . & $r v .0$ & 11 & $V r .0$ & rq & 7 & \\
\hline$\cdot . \leqslant \leq$ & $\cdot$ & - & rr.o & 14 & TV.O & $r v$ & $v$ & \\
\hline$\cdot . \leqslant \leq$ & . & . & rY.o & ir & TV.0 & $r v$ & $\wedge$ & \\
\hline$\cdot . \leqslant r$ & . & . & $r$. & Ir & $v$. & $r \wedge$ & 9 & \\
\hline$\because \leqslant V$ & • & • & $\varepsilon$. & 17 & 7. & $r \leqslant$ & 1. & \\
\hline$\cdot . \leqslant r$ & $\cdot$ & . & $r$. & Ir & $v$. & $r \wedge$ & 11 & \\
\hline$\cdot .4$ & $\cdot$ & · & $r$. & Ir & $v$. & $r \wedge$ & Ir & \\
\hline$\cdot . r q$ & . & - & IV.0 & v & Ar.o & $r r$ & ir & \\
\hline$\cdot r v$ & · & - & 1. & $\varepsilon$ & 9. & rq & $1 \leqslant$ & \\
\hline$\cdot . r \Lambda$ & $\cdot$ & - & 10 & 7 & 10 & $r \varepsilon$ & 10 & \\
\hline$\because \leqslant 1$ & · & · & r. ${ }^{\circ} 0$ & 9 & $V V .0$ & 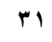 & 18 & \\
\hline$\cdot . \leqslant r$ & & & & & \multicolumn{3}{|c|}{ جملة المهارة } & \\
\hline$\because 0$. & $\cdot$ & . & o. & $r$. & 0 . & $r$. & 1 & \multirow{4}{*}{ 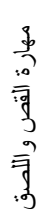 } \\
\hline$\cdot . \leqslant \Lambda$ & $\cdot$ & • & $\leqslant r .0$ & iv & $\Delta V_{.} \theta$ & $r r$ & r & \\
\hline$\cdot$. & $\cdot$ & • & $r$. & $\wedge$ & $\wedge$. & rr & $r$ & \\
\hline$\because r \Lambda$ & . & - & 19.0 & 0 & Av. 0 & ro & $\varepsilon$ & \\
\hline
\end{tabular}

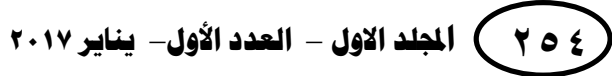


أ.د / ماجدة هاشم بخيت

أ.م .د/ عبيز سروه عبد الحمبد آديد

أثر أستخدام استراتيجية التعلم التعاونى

أ / شيرين محمود عبد الحميا عبل الحميل

\begin{tabular}{|c|c|c|c|c|c|c|c|c|}
\hline \multicolumn{9}{|c|}{ مهارات الملاحظة للعينة التجريبية فى التطبيق القبلى } \\
\hline \multirow{2}{*}{ 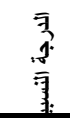 } & \multicolumn{2}{|c|}{ 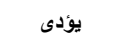 } & \multicolumn{2}{|c|}{ 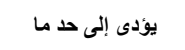 } & \multicolumn{2}{|c|}{ لايؤدى } & \multirow{2}{*}{ 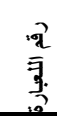 } & \multirow{11}{*}{$\begin{array}{l}\overline{3} \\
\overline{3}\end{array}$} \\
\hline & $\%$ & 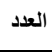 & $\%$ & 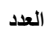 & $\%$ & 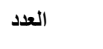 & & \\
\hline 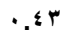 & . & - & r. & ir & v. & rی & $\bullet$ & \\
\hline$\cdot \leqslant r$ & • & - & $r \cdot$ & ir & $v \cdot$ & rA & 7 & \\
\hline$\cdot . r$ & · & - & r. & ir & v. & $r \wedge$ & $v$ & \\
\hline$\cdot . \mu \Lambda$ & · & - & 10 & 7 & 10 & $r \leq$ & $\wedge$ & \\
\hline$\cdot . r q$ & • & · & $1 v .0$ & $v$ & Ar.० & $r r$ & 9 & \\
\hline$\cdot .4$ & • & · & V.० & $r$ & 94.0 & $r v$ & 1. & \\
\hline$\cdot r^{q}$ & · & - & $1 Y .0$ & 0 & AV.० & ro & 11 & \\
\hline$\because$. & · & . & $r$. & $\wedge$ & $\wedge$. & rr & Ir & \\
\hline$\cdot$. & & & & & \multicolumn{3}{|c|}{ جملة المهارة } & \\
\hline$\therefore 0$. & . & . & 0 . & $r$. & o. & r. & 1 & \multirow{15}{*}{$\begin{array}{l}7 \\
: 0 \\
7 \\
7 \\
.9 \\
: 9\end{array}$} \\
\hline$\cdot . \leqslant r$ & . & . & $r V_{.} 0$ & 11 & VY.O & rq & $r$ & \\
\hline..$r q$ & . & - & $1 V_{0} 0$ & v & Ar.o & $r r$ & $r$ & \\
\hline$\because \leqslant 1$ & . & - & rY.O & 9 & $V V_{.} 0$ & 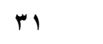 & $\varepsilon$ & \\
\hline$\cdot . \leqslant r$ & . & - & ro & 1. & vo & $r$. & - & \\
\hline$\cdot . \leqslant r$ & · & - & $r$. & ir & $v$. & $r \wedge$ & 7 & \\
\hline 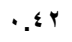 & · & - & ro & 1. & vo & $r$. & V & \\
\hline..$r q$ & · & - & $1 v .0$ & v & Ar.o & rr & $\wedge$ & \\
\hline$\because \leqslant 1$ & . & - & rY.O & 9 & $V V_{.} 0$ & r & 9 & \\
\hline$\because \leqslant r$ & . & · & $r$. & ir & $v \cdot$ & $r \wedge$ & 1. & \\
\hline$\cdot . \leqslant$ & . & - & rV.o & 11 & VY.O & rq & 11 & \\
\hline$\cdot . r q$ & . & . & iv.o & v & Ar.o & $r r$ & Ir & \\
\hline 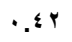 & . & - & ro & 1. & vo & $r$. & ir & \\
\hline ט. & . & - & • & r & 90 & $r \Lambda$ & $1 \leqslant$ & \\
\hline \multirow[t]{5}{*}{ 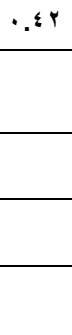 } & & & & & \multicolumn{3}{|c|}{ جملة المهارة } & \\
\hline & & & & & & $.9 \mathrm{~V}$ & \multicolumn{2}{|c|}{ المتوسط المرجح } \\
\hline & & & & & & $\because \cdot v$ & \multicolumn{2}{|c|}{ الخطا المعيارى } \\
\hline & & & & & & $\cdot A r$ & \multicolumn{2}{|c|}{ الحد الاعلى للثقة } \\
\hline & & & & & & $.0 Y$ & \multicolumn{2}{|c|}{ الحد الادنى للثقة } \\
\hline
\end{tabular}




\section{المجلة العلمية لكلية رياض الاطفال - جامعة اسيوط}

يتضح من جدول (ع) أنه كان هناك انخفاض ملحوظ في منوسطى درجات الأطفال في

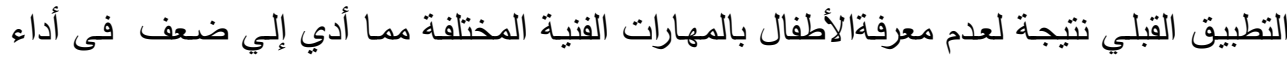

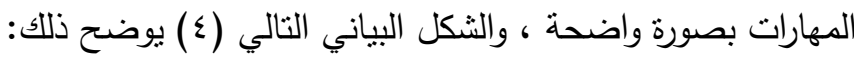
متوسط درجات الأطفال فى بطاقة الملاحظة التطبيق القبلى :

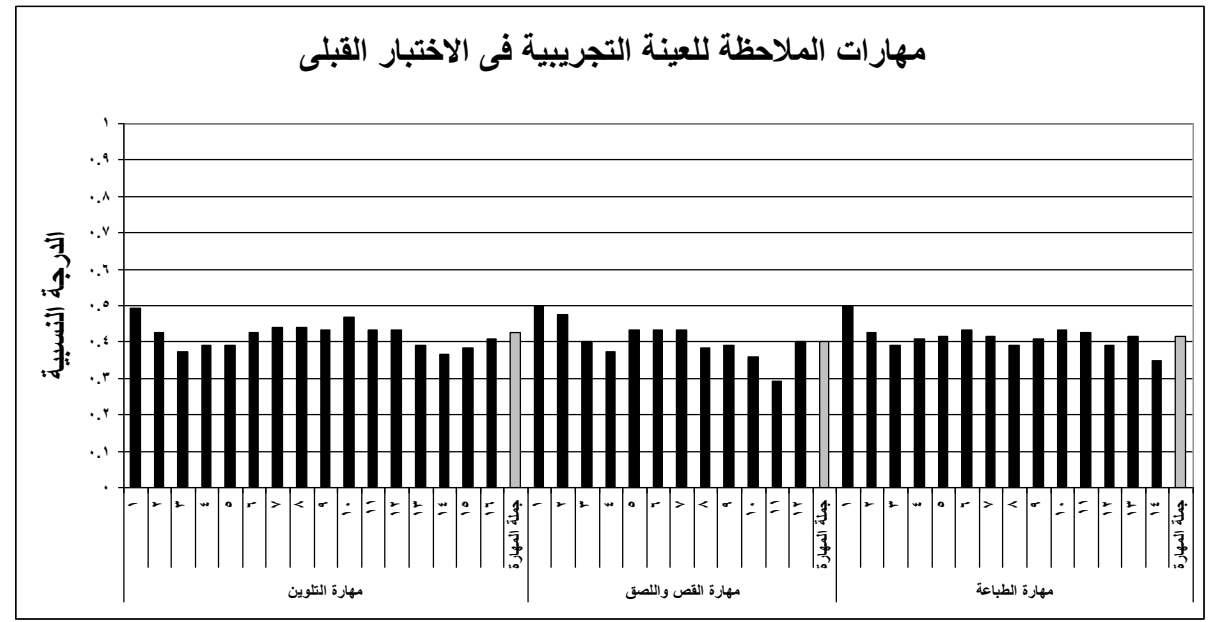

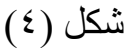

جدول (0)

مهارات الملاحظة للعينة التجريبية فى التطبيق البعدى حيث (ن=. ؛ )

\begin{tabular}{|c|c|c|c|c|c|c|c|c|}
\hline \multicolumn{9}{|c|}{ مهارات الملاحظة للعينة التجريبية فى التطبيق البعدى } \\
\hline \multirow{2}{*}{ 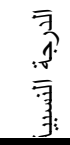 } & \multicolumn{2}{|c|}{ 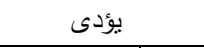 } & \multicolumn{2}{|c|}{ يؤدى إلى حد ما } & \multicolumn{2}{|c|}{ 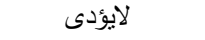 } & \multirow{2}{*}{$\begin{array}{l}\text { :वृ } \\
\overline{3}\end{array}$} & \multirow{2}{*}{$\overline{\overline{3}}$} \\
\hline & $\%$ & 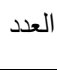 & $\%$ & العدد & $\%$ & 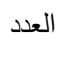 & & \\
\hline$\because \vee \wedge$ & M.O. & M & $7 V .0$. & $r v$ & $\cdots$ & - & 1 & \multirow{9}{*}{ 每 } \\
\hline .10 & $00 \ldots$ & Tr & $\leqslant 0 \ldots$ & 11 & $\cdots$ & - & r & \\
\hline$\cdot \wedge 1$ & $\leq Y .0$. & iv & $0 \vee .0$. & 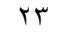 & $\cdots$ & - & $r$ & \\
\hline.$\vee \vee 9$ & rV.o. & 10 & Tr.0. & ro & $\cdots$ & . & $\varepsilon$ & \\
\hline$\cdot . \wedge 1$ & $\varepsilon r .0$. & IV & $0 \vee .0$. & מזr & $\cdots$ & . & 0 & \\
\hline.$\wedge 7$ & $0 \vee .0$. & זtr & $\varepsilon r .0$. & iv & $\cdots$ & • & 7 & \\
\hline$\cdot . \wedge r$ & $0 . .$. & $r$. & $0 . .$. & $r$. & $\cdots$ & • & V & \\
\hline$\cdot \wedge$. & $\varepsilon \ldots$ & 17 & $7 \ldots$ & $r \varepsilon$ & $\cdots$ & • & $\wedge$ & \\
\hline..$\wedge \Lambda$ & TY.O. & ro & rv.o. & 10 & $\ldots$ & . & 9 & \\
\hline
\end{tabular}


أ.د / ماجدة هاشم بخيت

أ.م .د/ عبيز سروه عبد الحمبد هيد

أثر أستخدام استراتيجية التعلم التعاونى

أ / شيرين محمود عبد الحميد عبد الحميا

\begin{tabular}{|c|c|c|c|c|c|c|c|c|}
\hline \multicolumn{9}{|c|}{ مهارات الملاحظة للعينة التجريبية فى التطبيق البعدى } \\
\hline \multirow{2}{*}{ 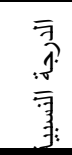 } & \multicolumn{2}{|c|}{ يؤدى } & \multicolumn{2}{|c|}{ يؤدى إلى حد ما } & \multicolumn{2}{|c|}{ لايؤدى } & \multirow{2}{*}{$\begin{array}{l}: 97 \\
\overline{7} .0\end{array}$} & \multirow{10}{*}{$\frac{\overline{3}}{\overline{3}}$} \\
\hline & $\%$ & العدد & $\%$ & العدد & $\%$ & العدد & & \\
\hline س & $0 . .$. & r. & $0 . .$. & r. & $\cdots$ & . & 1. & \\
\hline.$\wedge \varepsilon$ & or.o. & $r_{1}$ & $\varepsilon V .0$. & 19 & $\ldots$ & . & 11 & \\
\hline.$\wedge 1$ & $\leqslant$ Y.o. & iv & ov.o. & rT & $\cdots$ & . & ir & \\
\hline.$\vee q 9$ & rv.o. & 10 & Tr.O. & ro & $\cdots$ & . & Tr & \\
\hline.$V r$ & $r . .$. & $\wedge$ & $\wedge . .$. & rr & $\cdots$ & . & $1 \leq$ & \\
\hline.$v \varepsilon$ & r..o. & 9 & VV.O. & M & $\ldots$ & . & 10 & \\
\hline.$\wedge 1$ & $\varepsilon r .0$. & iv & $0 V .0$. & rT & $\cdots$ & . & 17 & \\
\hline.$\wedge 1$ & & & & & \multicolumn{3}{|c|}{ جملة المهارة } & \\
\hline.$v \varepsilon$ & Yr.o. & 9 & $V V .0$. & ו & $\cdots$ & . & 1 & \multirow{13}{*}{ 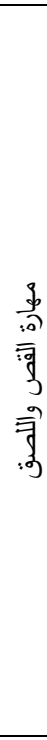 } \\
\hline.$\vee \vee q$ & rv.o. & 10 & Tr.O. & ro & $\cdots$ & . & r & \\
\hline.$\wedge 1$ & $\varepsilon r .0$. & IV & ov.o. & rT & $\cdots$ & . & $r$ & \\
\hline.$\wedge \mathrm{T}$ & ov.o. & rtr & $\varepsilon$ r.o. & iv & $\ldots$ & . & $\varepsilon$ & \\
\hline rی. & or.o. & TI & $\leqslant 0 .$. & 11 & T.O. & 1 & 0 & \\
\hline$\because \vee \wedge$ & $\varepsilon r .0$. & iv & $0 . .$. & $r$. & V.o. & $r$ & 7 & \\
\hline.$\wedge 1$ & $\leqslant \vee .0$. & 19 & $\leqslant \vee .0$. & 19 & $0 .$. & r & v & \\
\hline ז & $7 . .$. & $r \leq$ & $r . .$. & IT & $1 \ldots$ & $\varepsilon$ & $\wedge$ & \\
\hline .110 & $00 \ldots$ & rt & $\leqslant 0 \ldots$ & 11 & $\cdots$ & . & 9 & \\
\hline.$\wedge \varepsilon$ & $7 . .$. & $r \leq$ & Tr.O. & $1 T$ & V.o. & $r$ & 1. & \\
\hline..$\wedge \Lambda$ & AV.०. & ro & Ir.o. & 0 & $\cdots$ & . & 11 & \\
\hline.$\wedge \Lambda$ & $\pi .0$ & ro & rv.o. & 10 & $\cdots$ & . & ir & \\
\hline r. & & & & & \multicolumn{3}{|c|}{ 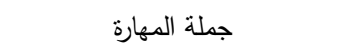 } & \\
\hline . Ar & $\leq 0 .$. & 11 & $00 \ldots$ & rr & $\cdots$ & . & 1 & \multirow{8}{*}{$\begin{array}{l}\frac{3}{80} \\
\frac{7}{7} . \\
\frac{9}{0}\end{array}$} \\
\hline.$\wedge V$ & $7 \ldots$ & $r \varepsilon$ & $\varepsilon \ldots$ & 17 & $\cdots$ & . & r & \\
\hline .10 & $00 \ldots$ & rT & $\leqslant 0 \ldots$ & 11 & $\cdots$ & . & $r$ & \\
\hline .9 & $v \cdot \ldots$ & rᄉ & $r . .$. & IT & $\cdots$ & . & $\varepsilon$ & \\
\hline .10 & $00 \ldots$ & r & $\leq 0 \ldots$ & 11 & $\cdots$ & . & 0 & \\
\hline$\cdot . \wedge 1$ & $\leqslant$ \&.०. & iv & ov.o. & rT & $\cdots$ & . & 7 & \\
\hline.$\wedge \vee$ & $7 . .$. & $r \leq$ & $\varepsilon \ldots$ & 17 & $\cdots$ & . & V & \\
\hline$\cdot . \wedge \varepsilon$ & or.o. & rI & $\varepsilon V .0$. & 19 & $\ldots$ & . & $\wedge$ & \\
\hline
\end{tabular}

$r$ r r r r الجبد الاول - العدد الأول- يناير 
المجلة العلمية لكلية رياض الاطفال - جامعة اسيوط

\begin{tabular}{|c|c|c|c|c|c|c|c|c|}
\hline \multicolumn{9}{|c|}{ مهارات الملاحظة للعينة التجريبية فى التطبيق البعدى } \\
\hline 亏 & \multicolumn{2}{|c|}{ 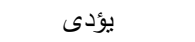 } & \multicolumn{2}{|c|}{ يؤدى إلى حد ما } & \multicolumn{2}{|c|}{ 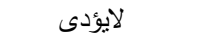 } & \multirow{2}{*}{$\frac{\sqrt[2]{2}}{\overline{3}}$} & \multirow{9}{*}{$\frac{\overline{3}}{\sqrt[3]{0}}$} \\
\hline 雪 & $\%$ & العدد & $\%$ & 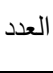 & $\%$ & العدد & & \\
\hline.$\wedge \varepsilon$ & or.o. & ץ) & $\leqslant \vee .0$. & 19 & $\cdots$ & - & 9 & \\
\hline.$\wedge \wedge$ & TY.O. & ro & rv.o. & 10 & $\cdots$ & • & $1 \cdot$ & \\
\hline.$\wedge 1$ & $\leqslant$ r.o. & iv & $0 \vee .0$. & rt & $\cdots$ & . & 11 & \\
\hline .10 & $00 \ldots$ & Tr & $\leqslant 0 \ldots$ & 11 & $\cdots$ & . & IT & \\
\hline.$V T$ & $10 \ldots$ & 7 & 10... & $T \varepsilon$ & $\cdots$ & . & $1 \pi$ & \\
\hline.$V Y$ & $10 \ldots$ & 7 & 10 & re & $\cdots$ & • & $1 \varepsilon$ & \\
\hline \multirow[t]{5}{*}{$\cdot . \wedge 0$} & \multicolumn{7}{|c|}{ جملة المهارة } & \\
\hline & & & & & & $.7 \mathrm{~V}$ & \multicolumn{2}{|c|}{ المتوسط المرجح } \\
\hline & & & & & & $\cdots V$ & \multicolumn{2}{|c|}{ الخطا المعيارى } \\
\hline & & & & & & $\cdot . \wedge r$ & \multicolumn{2}{|c|}{ الحد الاعلى للتقة } \\
\hline & & & & & & $.0 Y$ & \multicolumn{2}{|c|}{ الحد الادنى للثقة } \\
\hline
\end{tabular}

ويتضح من جدول (0) أن هناك تحسن ملحوظ في أداءالأطفال للمهارات الفنية التي

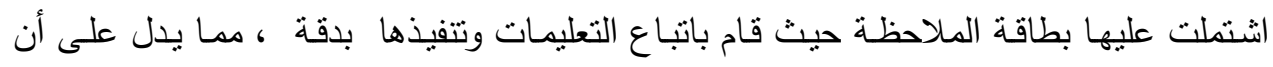

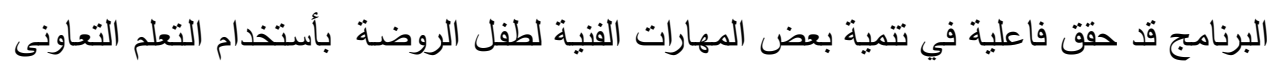

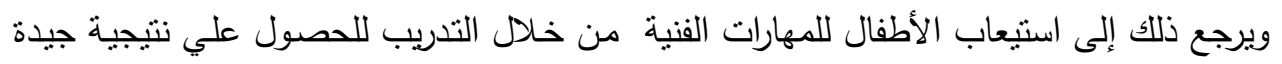

كوالثكل البياني النالي يوضح ذللك: شكل رقم (0) 
أ.د / ماجدة هاشم بخيت

أ.م .د/ عبيز سروه عبد الحمبيد

أثر أستخدام استراتيجية التعلم التعاونى

أ / شيرين محمود عبد الحميد

مهارات الملاحظة للعينة التجرييية فى الاختبار البعدى

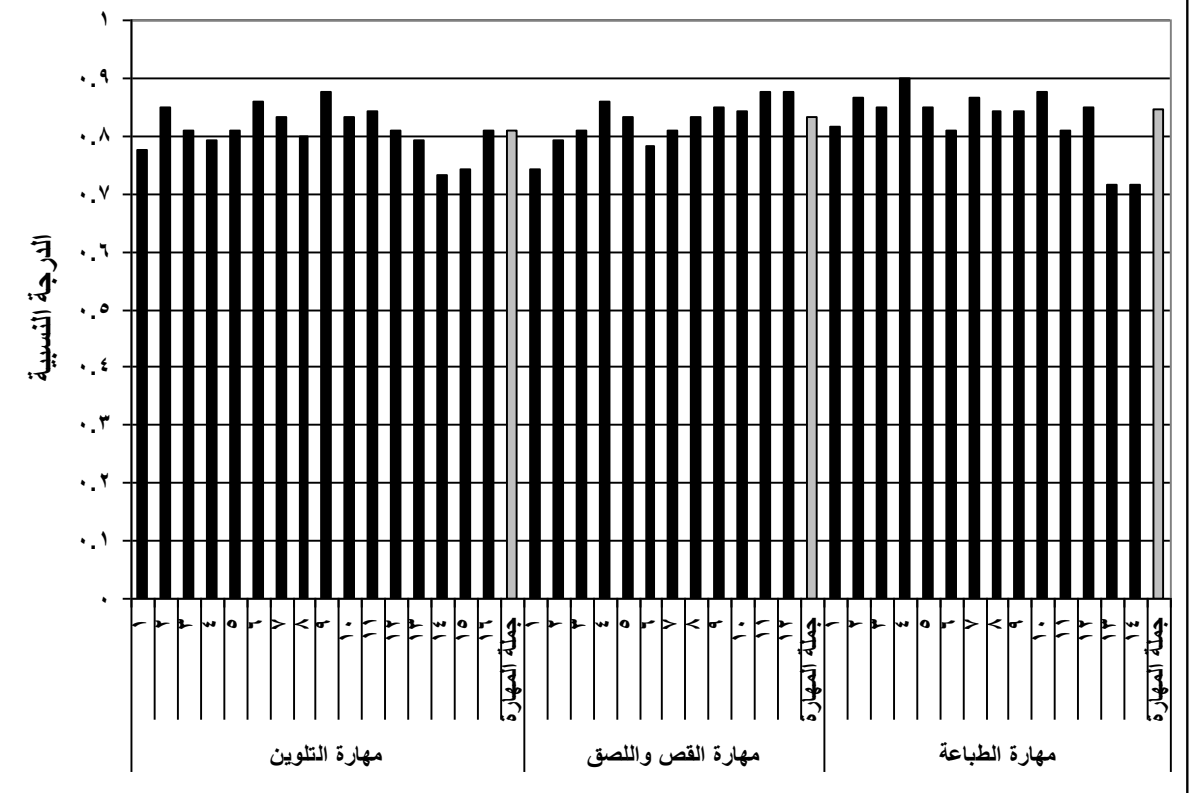

شكل رقم (•) 


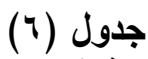

الفرق بين استجابات العينة التجريبية في الاختبارين القبلي والبعدي ودرجة الكسب التبائي

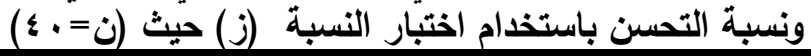

\begin{tabular}{|c|c|c|c|c|c|c|c|c|}
\hline \multicolumn{9}{|c|}{ الفرق فى مهارات الملاحظة للعينة التجريبية بين التطبيق القبلى والبعدى } \\
\hline \multirow{2}{*}{ التحسن \% } & \multirow{2}{*}{ الاثر } & \multirow{2}{*}{ معدل } & \multicolumn{2}{|c|}{ اختبار ز } & \multicolumn{2}{|c|}{ الارجة النسبية } & \multirow{2}{*}{ 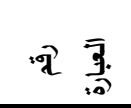 } & \multirow{2}{*}{$\begin{array}{l}\overline{3} \\
\overline{3}\end{array}$} \\
\hline & & & 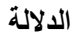 & 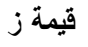 & 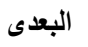 & 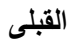 & & \\
\hline זיר. & $\varepsilon \ldots$ & $\cdot . \wedge \varepsilon$ & $\cdot, .0$ & 1.71 &.$\vee \wedge$ & $\cdot . \leqslant 9$ & 1 & \multirow{17}{*}{ 可 } \\
\hline $1 \ldots \ldots$ & 7. . V & 1.17 & $\cdot, \cdot 0$ & T. $\leqslant$ Y & .10 & $\cdot . \leqslant r$ & r & \\
\hline 110.07 & 7.19 & 1.11 & $\cdot, .0$ & Y. $\leqslant 7$ & $\cdot . \wedge 1$ &.$r \Lambda$ & r & \\
\hline $1 \cdot r .14$ & $0 . \times 1$ & $1 .+7$ &., .0 & T.TV &.$v 9$ &.$r q$ & $\varepsilon$ & \\
\hline 1. T.r人 & 0.90 & 1.1. & $\cdot, .0$ & t.rv & $\cdot . \wedge 1$ &.$r q$ & 0 & \\
\hline 1.1 .97 & 7.19 & 1.19 & $\cdot, .0$ & T. $\leqslant V$ &.$\wedge 7$ & 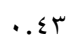 & 7 & \\
\hline$\wedge \wedge .7 \wedge$ & 0.7 . & $1 . .9$ & $\cdot, .0$ & Tr.t & . & $\cdot . \leqslant \varepsilon$ & V & \\
\hline $11.1 \pi$ & 0.11 & $1 \ldots$ & $\cdot, .0$ & Y.. $\varepsilon$ & $\cdot \wedge$. & $\cdot . \leqslant \varepsilon$ & $\wedge$ & \\
\hline $1.1 .9 r$ & $7 . M$ & I.rT & $\cdot, .0$ & r.or & $\cdot . \wedge \wedge$ & 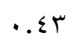 & 9 & \\
\hline $\mathrm{VA.} .0 \mathrm{~V}$ & $0 . Y \leq$ & 1.00 & $\cdot, .0$ & T.. q & . . & $\cdot \leqslant \leqslant V$ & 1. & \\
\hline Qร.Tr & ט.人 & 1.11 & $\cdot, .0$ & אז.ץ & $\cdot . \wedge \varepsilon$ & 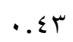 & 11 & \\
\hline $17.0 \leqslant$ & ד.r & $1 . . \varepsilon$ & $\cdot, .0$ & r.IT & $\cdot . \wedge 1$ & 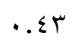 & ir & \\
\hline I.r.IT & 0.71 & $1 . .7$ & $\cdot, .0$ & T.TV &.$\vee 99$ &.$r q$ & Tr & \\
\hline $1 \ldots$ & $0 . Y \varepsilon$ & .90 & $\cdot, .0$ & r..A &.$v r$ &.$r v$ & $1 \varepsilon$ & \\
\hline $9 r . \varepsilon \wedge$ & 0.11 & .98 & $\cdot, .0$ & r..r &.$v \varepsilon$ &.$r \Lambda$ & 10 & \\
\hline 97.97 & 0.11 & $1 . .1$ & $\cdot, .0$ & T.TV & $\cdot .11$ & . $\leqslant 1$ & 17 & \\
\hline q..T. & $0 . \leqslant 1$ & 1.00 & $\cdot, .0$ & Y.11 & $\cdot . \wedge 1$ & . . $\leqslant T$ & جملة المهارة & \\
\hline & r. $\leqslant 0$ &.$v r$ & $\cdot, .0$ & $1 . \mathrm{r}$ &.$V \varepsilon$ & .0 . & 1 & \multirow{7}{*}{ 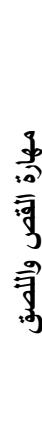 } \\
\hline 77. & $\varepsilon .0 Y$ & .99 & $\cdot, .0$ & 1.1. &.$v 9$ &..$\leqslant \wedge$ & r & \\
\hline I.r.. & 0.Ar & $1 . .9$ & $\cdot, .0$ & T.r &.$\wedge 1$ & $\because \varepsilon$. & r & \\
\hline IY^.^9 & 7.9. & 1.57 & $\cdot, .0$ & T.Vo &.$\wedge 7$ &.$r \Lambda$ & $\varepsilon$ & \\
\hline QY.Tा & 0.11 & 1.11 & $\cdot, \cdot 0$ & r.Y人 & rی. & . & 0 & \\
\hline$\Lambda . . V V$ & $0 .$. & $.9 V$ & $\cdot, .0$ & 1.99 & $\because \vee \wedge$ & 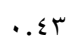 & 7 & \\
\hline $17.0 \leqslant$ & $0 . r 4$ & $1 . . \varepsilon$ & $\cdot, .0$ & r.IT & $\cdot . \wedge 1$ & r & $V$ & \\
\hline
\end{tabular}


أ.د / ماجدة هاشم بخيت

أ.م .د/ عبيز سروه عبد هايد الحميد

أثر أستخدام استراتيجية التعلم التعاونى

أ / شيرين محمود عبد الحميد

\begin{tabular}{|c|c|c|c|c|c|c|c|c|}
\hline \multicolumn{9}{|c|}{ الفرق فى مهارات الملاحظة للعينة التجرييية بين التطبيق القبلى والبعدى } \\
\hline \multirow{2}{*}{ التحسن \%\% } & \multirow{2}{*}{ الاثر } & \multirow{2}{*}{ الكسب معل } & \multicolumn{2}{|c|}{ اختبار ز } & \multicolumn{2}{|c|}{ الارجة النسبية } & \multirow{2}{*}{ 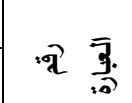 } & \multirow{8}{*}{ 亨 } \\
\hline & & & الالالة الة & 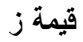 & 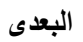 & 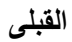 & & \\
\hline $11 \mathrm{V.rq}$ & ר. & 1.11 & $\cdot, .0$ & Y.07 & $\cdot . \wedge r$ & 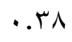 & $\wedge$ & \\
\hline $11 \mathrm{~V} . \mathrm{r}$ & 7.00 & $1 . Y$ & $\cdot, .0$ & Y.71 & $\therefore$. &.$r q$ & 9 & \\
\hline $\mid r \varepsilon . \wedge \wedge$ & 7.9 . & $1 . r \leq$ & $\cdot, .0$ & Y.Vo & $\cdot . \wedge \varepsilon$ & דיח & 1. & \\
\hline 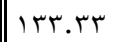 & V. $1 \leq$ & $1 . r$. & $\cdot, \cdot 0$ & Y.A० & $\cdot . \wedge \wedge$ &.$r \Lambda$ & 11 & \\
\hline $11 \wedge .20$ & 7.199 & $1 . r V$ & $\cdot, .0$ & Y.VI & $\cdot . \wedge \wedge$ & 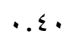 & Ir & \\
\hline س. & 7.19 & 1.17 & $\cdot, .0$ & Y. $\leqslant T$ & r. & $\therefore \varepsilon$. & جملة المهارة & \\
\hline אז.זד & $\varepsilon .0 Y$ & .90 & $\cdot, .0$ & 1.11 & . .AT & .0 . & 1 & \multirow{15}{*}{$\frac{3}{10}$} \\
\hline $1 . r .9 r$ & 7.41 & $1 . Y 1$ & $\cdot, .0$ & r.OT & $\cdot . \wedge \mathrm{V}$ & 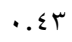 & r & \\
\hline $11 \mathrm{~V} . . \mathrm{r}$ & 7.00 & $1 . Y 1$ & $\cdot, .0$ & Y.TI & .10 &.$r q$ & $r$ & \\
\hline$|Y, . \varepsilon|$ & $V . . r$ & r. & $\cdot, .0$ & Y.AI & $\cdot 9$. & $\cdot . \leqslant 1$ & $\varepsilon$ & \\
\hline $1 . \varepsilon \ldots$ & 7.19 & 1.11 & $\cdot, .0$ & T. $\leqslant V$ & .10 & $\cdot . \leqslant r$ & 0 & \\
\hline 1.т.0 & דr. & $1 . . \varepsilon$ & $\cdot, .0$ & r. &. .11 & 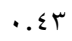 & 7 & \\
\hline $1 . \wedge . \ldots$ & $T . \leqslant r$ & I.Y & $\cdot, .0$ & T.OV & $\cdot . \wedge \vee$ & $\cdot . \leqslant r$ & V & \\
\hline $11 \leqslant . \wedge 9$ & ד. & 1.19 & $\cdot, .0$ & Y.07 & $\cdot \wedge \varepsilon$ & & $\wedge$ & \\
\hline $1.7 .1 \mathrm{r}$ & 7.19 & $1.1 \mathrm{~V}$ & $\cdot, .0$ & T.EV & $\cdot . \wedge \varepsilon$ & $\cdot . \leqslant 1$ & 9 & \\
\hline $1.1 .9 r$ & 7.41 & I.YY & $\cdot, .0$ & r.Or & $\cdot . \wedge \wedge$ & r & 1. & \\
\hline q... & $0 . \leqslant \wedge$ & 1.00 & $\cdot, .0$ & r.11 &. .11 & . . & 11 & \\
\hline $11 \mathrm{~V} . . \mathrm{r}$ & 7.00 & $1 . Y 1$ & $\cdot, .0$ & Y.TI & .10 & qq & ir & \\
\hline$V Y_{.}$. & E.rq &.$\wedge 1$ & $\cdot, .0$ & 1.8. &.$V T$ & $\cdot . \leqslant Y$ & r & \\
\hline $1 . \varepsilon . \vee 7$ & $0 . Y \leq$ & .94 & $\cdot, .0$ & r..人 &.$V Y$ & ס r. & $1 \varepsilon$ & \\
\hline I. ז.... & T.1T & 1.17 & $\cdot, .0$ & T. $\varepsilon \leqslant$ & .110 & 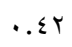 & جملة المهارة & \\
\hline & & & & & \multicolumn{2}{|c|}{.$T V$} & \multicolumn{2}{|c|}{ المتوسط المرجح } \\
\hline & & & & & \multicolumn{2}{|c|}{$\ldots v$} & \multicolumn{2}{|c|}{ الخطا المعيارى } \\
\hline & & & & & \multicolumn{2}{|c|}{.$\wedge r$} & \multicolumn{2}{|c|}{ الحد الاعلى للثقة } \\
\hline & & & & & \multicolumn{2}{|c|}{$.0 r$} & \multicolumn{2}{|c|}{ الحد الادنى للثقة } \\
\hline
\end{tabular}




\section{في ضوء الجدل السابق يتضح ما يلى :}

1- نوجد فروق ذات دلالة إحصائية عند مستوى (0. . • ) بين متوسطى درجات لفئ مجموعة الدراسة

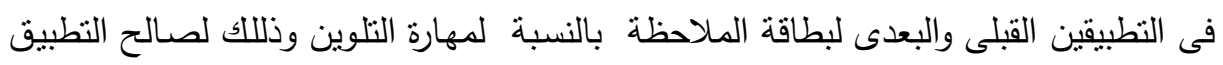

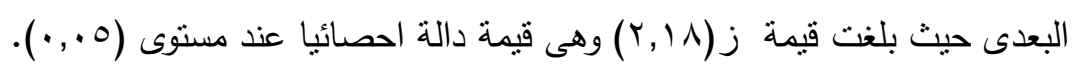

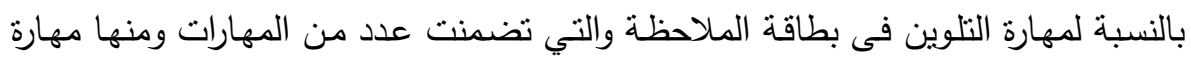

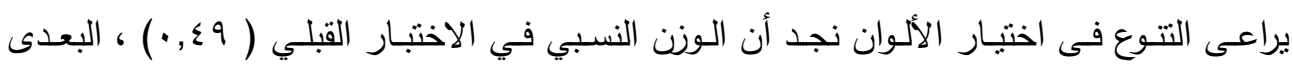

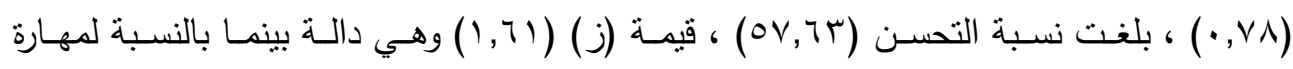

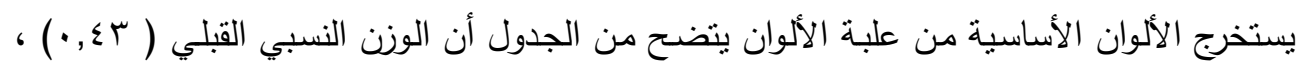

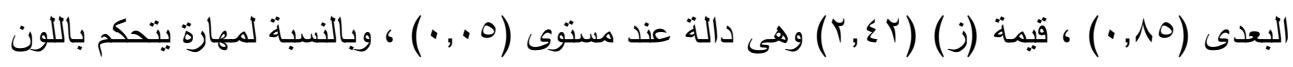

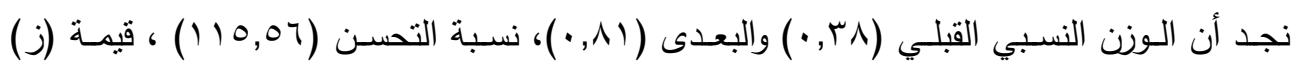

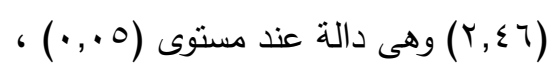

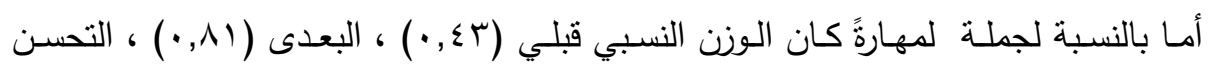

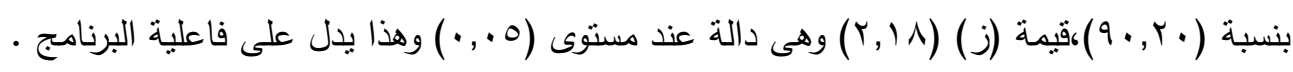

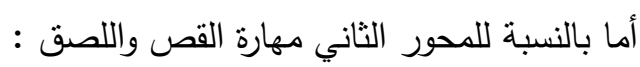

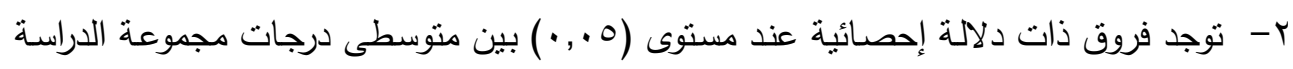

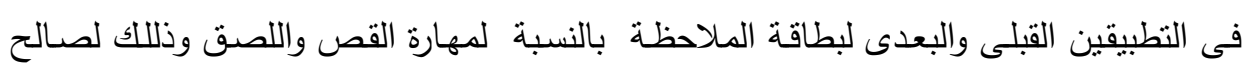
التطبيق البعدى حيث بلغت قيمة ز (T ع.ب) وهى قيمة دالة احصائيا عند مستوى (0. . . ).

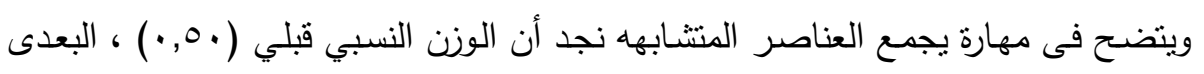

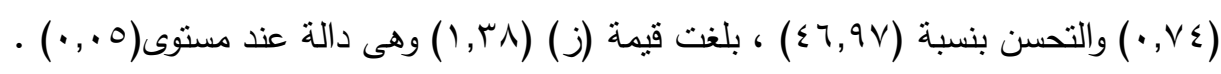

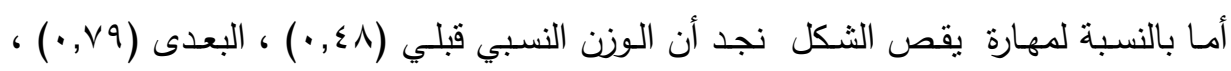

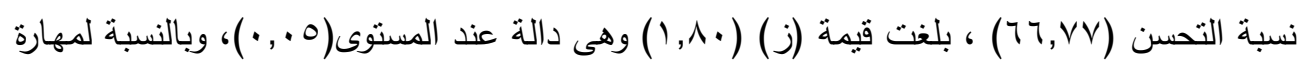

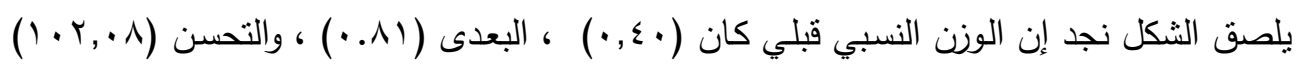

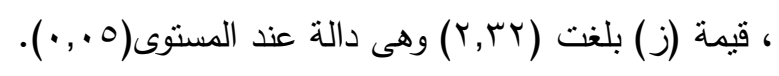

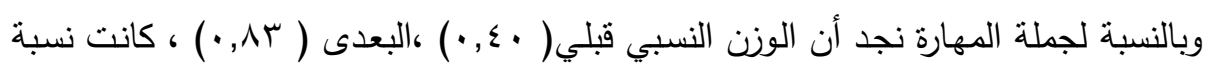

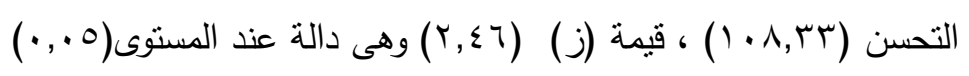


أ.د / ماجدة هاشم بخيت

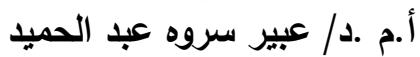

أثر أستخدام استراتيجية التعلم التعاونى

أ / شبيرين محمود عبد الحميد عبدو الحميد

أما بالنسبة للمهارات الخاصة بالمحور الثالث ( مهارة الطباعة ) :

ب- توجد فروق ذات دلالة إحصائية عند مستوى (0 . . • ) بين متوسطى درجات مجموعة الدراسة فى التطبيقين القبلى والبعدى لبطاقة الملاحظة بالنسبة لمهارة الطباعة وذللك لصالح التطبيق

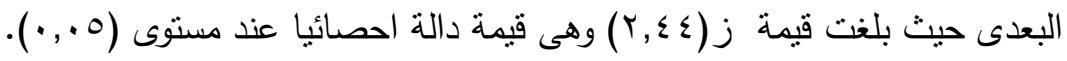

وفى مهارة بطبـع على القهـاش أو الـوق نجد أن الـوزن النسبي قبلي ( • • • ) ، البعدى

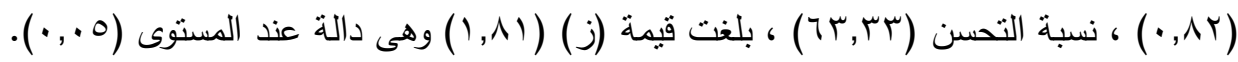

أما بالنسبة لمهارة يجيد الطباعة بالبصمة نجد أن الوزن النسبي قبلي كان (سع, •) ،البعدى

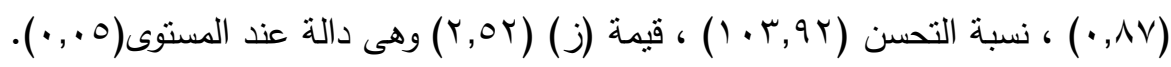

أمسا بالنسبة لمهارة يجيد الطباعة بالاستتسل نجد أن الوزن النسبي قبلي (q؟, • ) ،البعدى

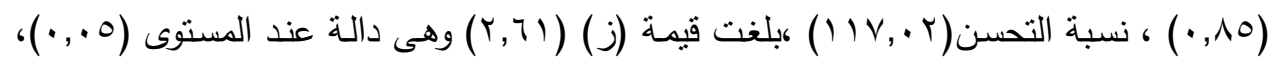

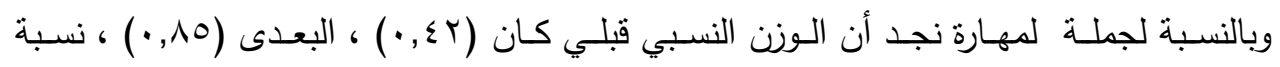

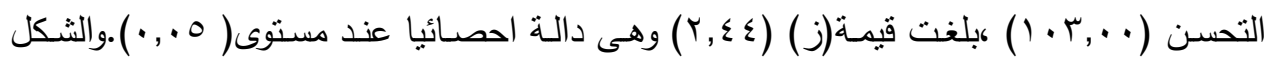
البيانى التالى يوضح : n

والشكل البيانى التالى يوضح :

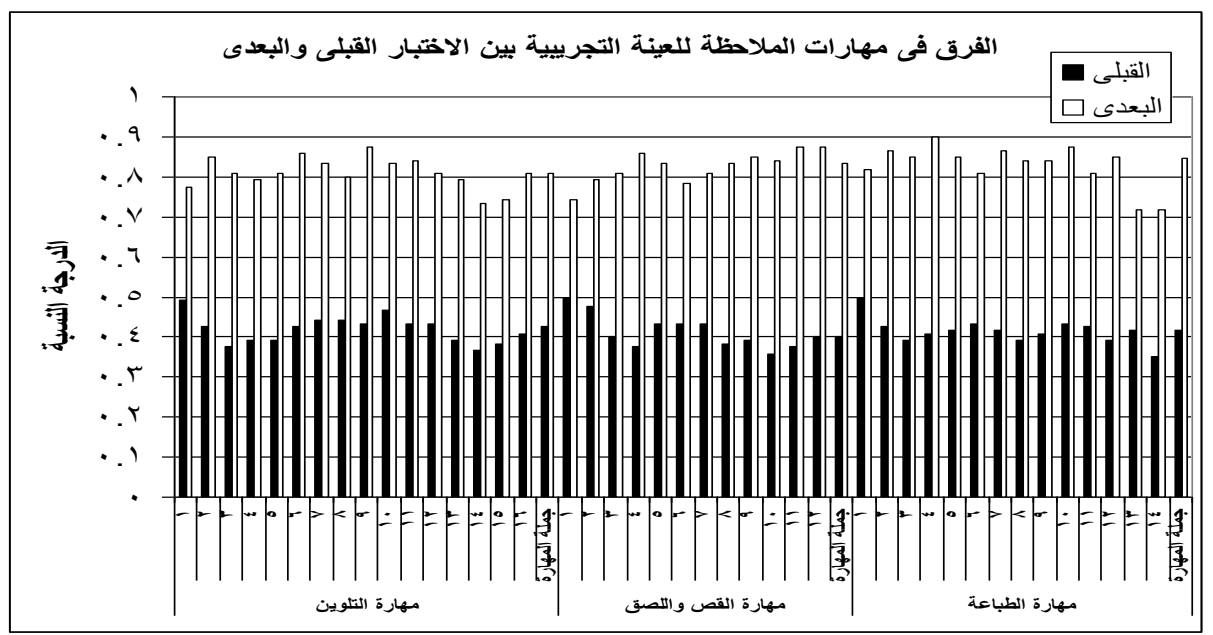

شكل (1)

حدود الثقة في التطبيق القبلي والبعدي 


\section{في العينة التجريبية - بطاقة الملاحظة}

أما بالنسبة للأختبار وأعادة الأختبار لجملة المهارات فى بطاقة الملاحظة نجد أن معامل

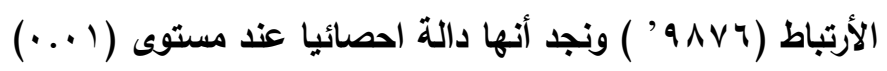

ومن الجداول (ع) ، (0) ، (ך) والثكل البيانى (ع) ، (0) ، (7) يتضح الآتي:

أولا : بالنسبة لمهارة التلوين :

- تمكن معظم الأطفال من تتفيذ المهارات الفنية بطريقة جيدة وكان ذلك واضحًا فى نلوين الأطفال

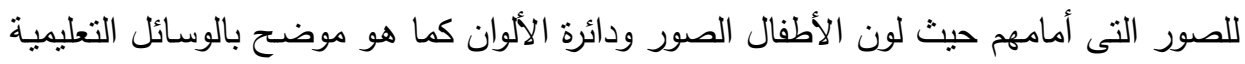

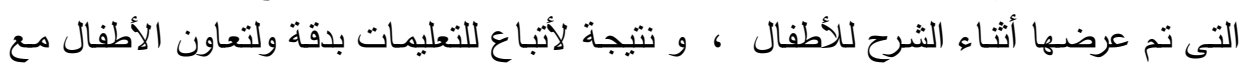

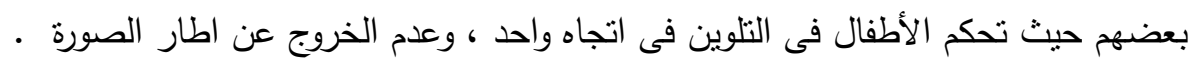

ثانيا :بالنسبة لمهارة القص واللصق

- كما ظهر لدي الأطفال دقة في جمع العناصر المتشابهه مع بعضها ، وقص الأثكال ولصقها

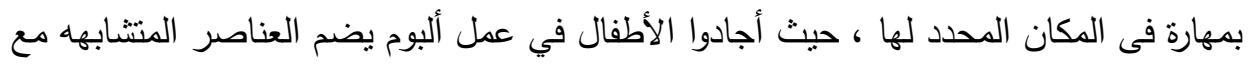
بعض

ثالثا: بالنسبة لمهارة الطباعة :

- حيث تفاعل الأطفال مع الخامة وتعاملوا معها حيث أجادوا الأطفال فى الطباعة بالبصمة

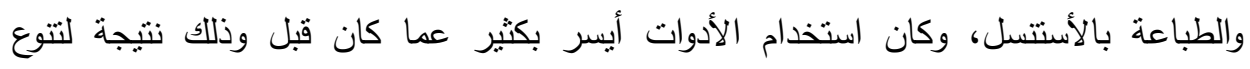

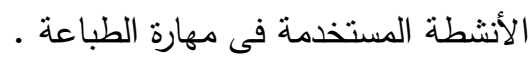

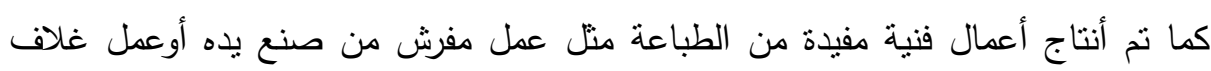

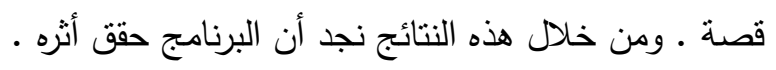

وتتفق نتائج هذه الدراسة مـع العديد من الدراسات التي تؤكد علي تتمية المهارات الفنية لطفل

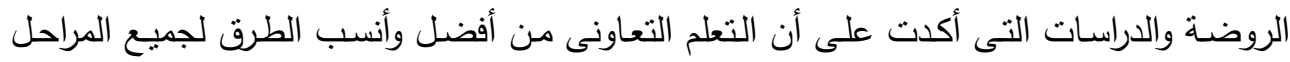

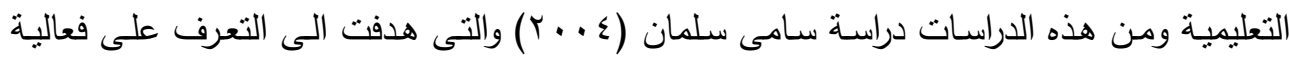

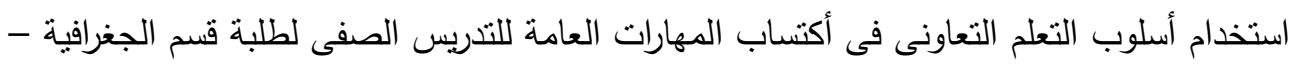

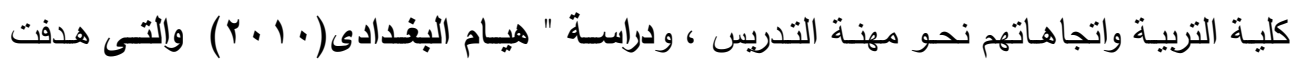

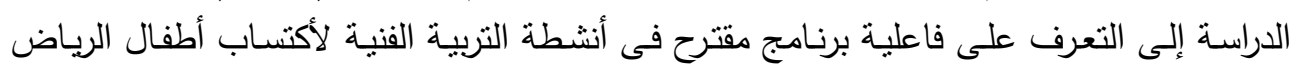

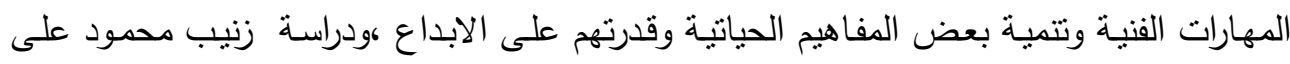

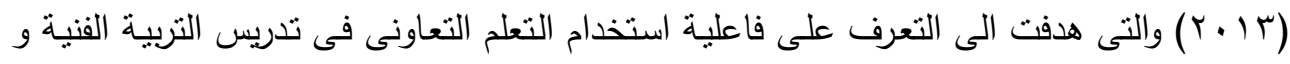


أ.د أد/ ماجدة هاشم بخيت

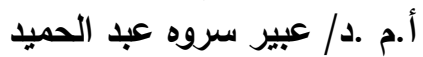

أثز أستخدام استراتيجية التعلم التعاونى

أ / شبيرين محمود عبد الحميد عبدو الحميد

أثره على تتميـة بعض المهارات التفكير الأبـداعى والأتجاه نحو مقرر التربيـة الفنيـة لـى طـلاب

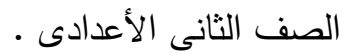

وللتحقق من صحة الفرض الثالث والذى ينص على :

توجد علاقة ارتباطية دالة احصائيا بين درجات مجموعة الدراسة فى مقياس المهارات الفنية وبطاقة الملاحظة فى التطبيث البعدى تم حساب معاملات الأرتباط بين مقياس المهارات القنية ويطاقة الملاحظة ( ن= r ب ) والجدول التالى يوضح ذلك :

معاملات الارتباط بين مجموع درجات المهارت ودرجات الملاحظة (ن=r r )

\begin{tabular}{|c|c|c|c|c|c|}
\hline \multicolumn{6}{|c|}{ معاملان الارتباط بين مجموع درجات المهارت ودرجات الملاحظة (ن=r r ب) } \\
\hline الدلالة & معامل ارتباط & الانحراف المعيرى & المتوسط & & \\
\hline$\cdot, \cdot 1$ & 0.561 & 1.704 & 39.182 & النلويين & \multirow{4}{*}{ بطاقة } \\
\hline$\cdot, \cdot 1$ & 0.469 & 1.454 & 30.364 & القص واللصق & \\
\hline$\cdot, .0$ & 0.401 & 1.293 & 35.121 & الطباعة & \\
\hline$\cdot, \cdot 1$ & 0.883 & 2.496 & 104.667 & مجوع املاحظة & \\
\hline$\cdot, .0$ & 0.349 & 1.251 & 19.424 & التلوبين & \multirow{4}{*}{ 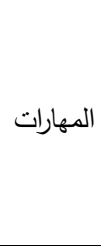 } \\
\hline$\cdot, .0$ & 0.377 & 0.972 & 21.152 & القص واللصق & \\
\hline \multirow[t]{4}{*}{$\cdot, \cdot 1$} & 0.944 & 3.015 & 20.697 & الطباعة & \\
\hline & & 3.015 & 20.697 & مجموع المهرات & \\
\hline & & & 0.3493 & قيمة ر الجدولية & \\
\hline & & &..$\leqslant \varepsilon \wedge V$ & قيمة ر الجدولية & \\
\hline
\end{tabular}

وهذا يدل على أن كلما زادت معرفة الطفل بمفاهيم المهارات الفنية كلما كان أدائه أفضل والعكس صحيح مما يعنى أن البرنامج يحقق أهدافه .

ويتضح من الجدول السابق بالنسبة للمهارات الفنية (مهارة التلوين ) نجد أن دعامل الأرتباط ( 9ะז, •) وهو دال إحصائيا عند مستوى (0., (·)، وبالنسبة( مهارة القص واللصق) نجد أن معامل الأزتباط (rVV, · •) وهو دال إحصائيا عند مستوى (0., . ) )، وبالنسبة (مهارة

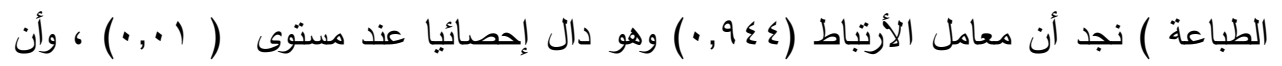




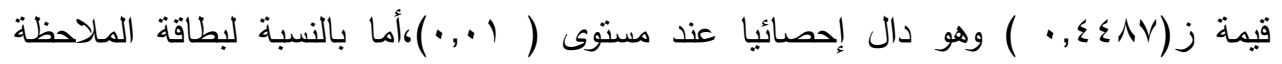
لمهارة التلوين

نجد أن معامل الأرتباط (1)07, •) وهو دال إحصائيا عند مستوى ( (.,.))، وبالنسبة

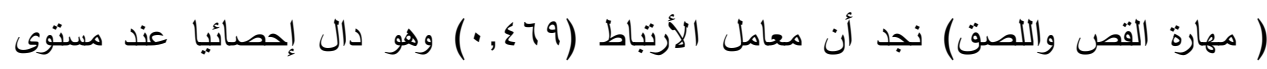

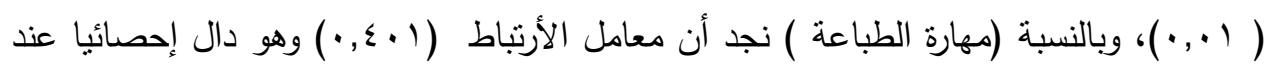

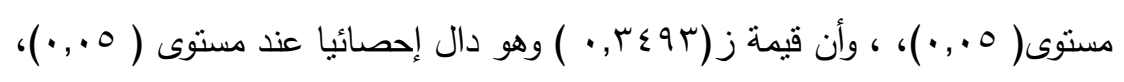

وهذا يدل على أن كلما زادت معرفة الطفل بمفاهيم المهارات الفنية كلما كان أدائه أفضل

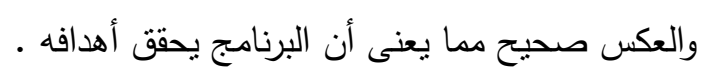
تفسير نتائج الفرض الثالث : - - توجد علاقة ارتباطية دالة احصائيا بين درجات مجموعة الدراسة فى مقياس المهارات الفنية وبطاقة ملاحظة لأداء الطفل للمهارات الفنية فى النطبيق البعدى ويرجع ذلك دربات إلى : - تنوع الأنشطة الفنية المستخدمة مع أطفال الروضة . - استخدام استراتيجية التعلم التعاونى وخاصة استراتيجية التعلم معا ـ - - جو الأثارة والتشويق الذى عم البرنامج واللقاءات الناتج عن التعزيزات المنتوعة للأطفال.

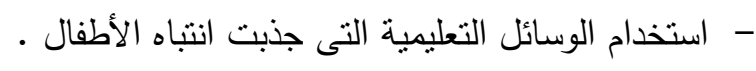
- تعاون الأطفال ومساعدة بعضهم

\section{تعقيب عام على نتائج الاراسة الحالية :}

خلصت النتائج التى تم التوصل إليها فى الدراسة الحالية إلى أهمية تتمية المهارت الفنية

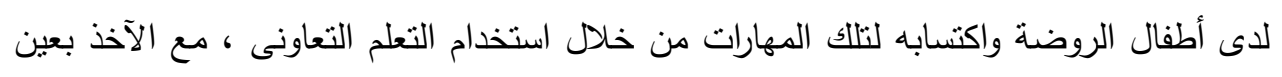

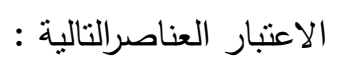

1- مناسبة المهارات الفنية التى انتملت عليها لقاءات البرنامج لأطفال الروضة . r- استخدام الوسائل التعليمية والأساليب التى تتلاءم مع خصائص طفل الروضة .

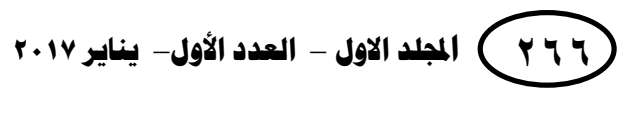


أ أد / ماجدة هاشم بخيت

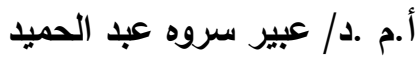

أثز أستخدام استراتيجية التعلم التعاونى

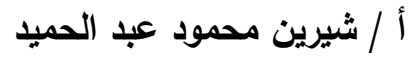

r- استخدام التقوبم المستمر قبل وأثناء وبعد لقاءات البرنامج •

وفى ضوء تحقق الفروض الثلاثة يتضح أنه يوجد أثر لاستخدام استراتيجية التعلم التعاونى

فى تتمية بعض المهارات الفنية لاى طفل الروضة ، وهذا هو ماهدفت إليه هذه الدراسة .

وتتفق نتائج هذه الدراسة مع العديد من الدراسات التي تؤكد علي تتمية المهارات الفنية لطفل

الروضة والدراسات التى أكدت على أن التعلم التعاونى من أفضل وأنسب الطرق لجميع المراحل التعليمية ومن هذه الدراسـات دراسـة سامى سلمان (ع . . ب) والتى هدفت الى التعرف على فعالية استخدام أسلوب التعلم التعاونى فى أكتساب المهارات العامة للتدريس الصفى لطلبة قسم الجغرافية -كلية التربية واتجاهاتهم نحو مهنة التدريس ، ودراسـة " هيبام البغدادى( • ( ب) والتى هدفت

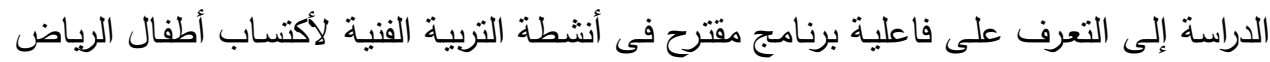
المهارات الفنية وتتمية بعض المفاهيم الحياتية وقدرتهم على الابداع ،ودراسـة زنيب محمود على

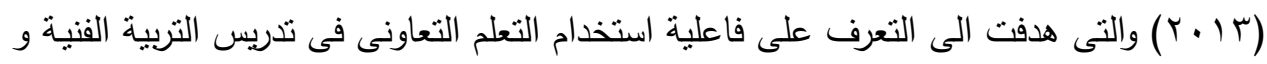
أثره على تتمية بعض المهارات التفكير الأبداعى والأتجاه نحو مقرر التربيـة الفنية لدى طلاب الصف الثانى الأعدادى . برهى 


\section{توصيات الاراسة:}

1. عمل دورات تدريبية بصفة مستمرة لمعلمات رياض الأطفال لتدريبهم على كل ماهو جديد.

r r إقامة ورش عمل متخصصة لتنمية المهارات الفنية لطفل الروضة .

r. إقامة معارض لأعمال الأطفال وذلك التتجعيهم على العمل الفنى .

ع. ضرورة الأهتمام بالأنشطة الفنية لدى أطفال الروضة .

ـ. الاهتمام بالدهارات الفنبة الآخرى لدى طفل الروضة .

\section{دراسات ويحوث مقترحة:}

1- دراسة تكميلية تهدف إلى تعرف الأطفال بعض المهارات الفنبة الأخرى .

r- فاعلية برنامج مقترح قائم على استخدام الأنشطة الفنية فى تتمية روح العمل الجماعى عند

$$
\text { طفل الروضة . - طاعلة برنامج }
$$

ب- برنامج مقترح قائم علي استخدام التعلم التعاونى فى تتمية مهارة الطباعة والنسيج لدى طفل

$$
\text { الروضة . }
$$

ـ - برنامج مقترح قائم على استخدام التعلم التعاونى فى تتمية المهارات الفنية عند معلمات رياض

الأطفال. 
أ أد / ماجدة هاشم بخيت

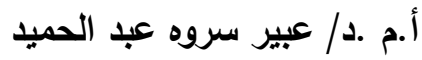

أثز أستخدام استراتيجية التعلم التعاونى

أ / شيرين محمود عبد الحميد

المراجـع

أولا : المراجع العربية :

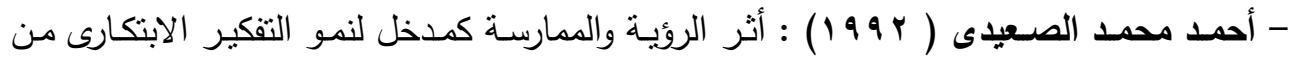
خلال تصميم حقيبة تعليمية لطفل ماقبل المدرسة ، رسالة ماجستير ، كلية التربية

، جامعة المنيا .

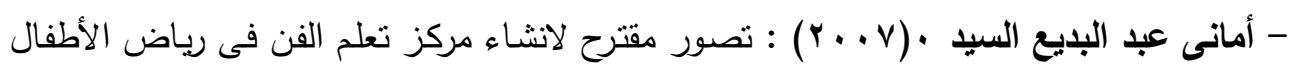

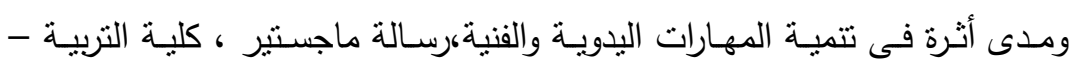

جامعة طنطا .

- أمنية محمد ابراهيم (^ . ץ): فاعلية استخدام الموديولات التعليمية والتعلم التعاونى فى تتمية

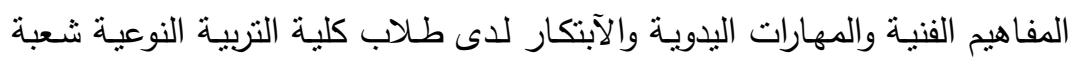

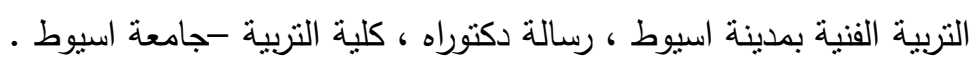

- جوزال عبد الرحيم ، عزة خليل ، كامليا عبد الفتاح ( . . ؟) : المناشط الفنية لطفل الرياض القاهرة ،مطابع الثروق.

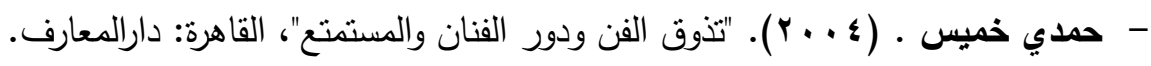

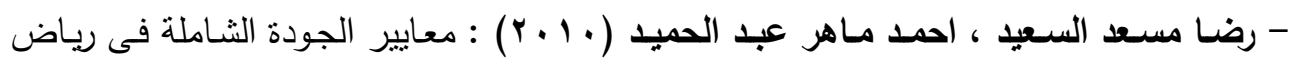

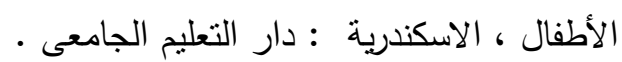

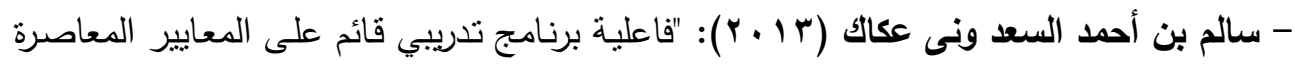
التمية المهارات المهنية لدى مشرفى التربية الإسلامية بسلطنة عمان" ، كلية التربية ، قسم المناهج وطرق التدريس ، جامعة أسيوط.

- سميرة ابو زيد ، سحر توفيق نسيم (؟ . ㄷ) : دليل المعلمات لانشطة رياض الاطفال : القاهرة

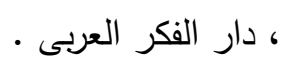


- عبد العزيز الخضراء (1 . ץ): التكامل بين البيت والمدرسة ، مجلة بناة الاجيال ، عرب ، ص

$$
.1 \vee 9-1 \vee \wedge \text { ص }
$$

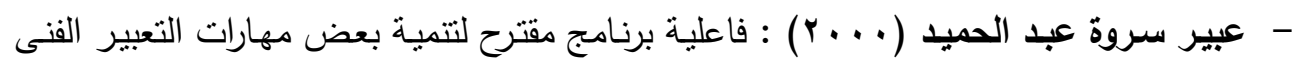
للتلاميـذ فـى ضـوء فـن الخـداع البصـرى ، رسـالة ماجسـتير ، كليـة التربيـة ،

$$
\text { جامعة اسيوط . }
$$

- فوزى عبد السـلام الشـريني (1 (1 ب)،"رؤيـة جديدة في طرق واستراتيجيات التدريس للتعليم الجامعي وما قبل الجامعي "، دمياط : المكتبة العصرية للنشر .

- فهيم مصطفى (0 . . r) : الطفل والمهارات الحياتية فى رياض الاطفال والمدرسة الابتدائية ، القاهرة ، دار الفكر العربى.

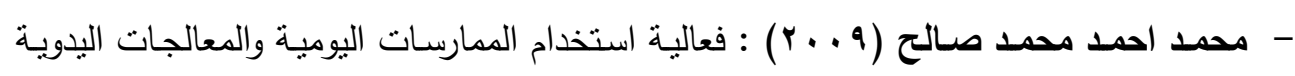
لاطفـال ماقبـل المدرسـة فى اكسـابهم بعض المفـاهيم الرياضـية وتتميـة التفكير

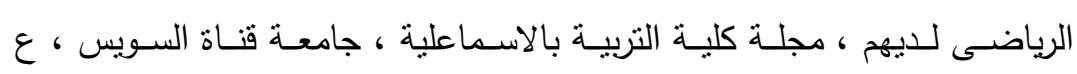

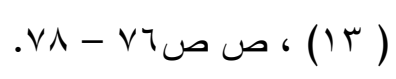

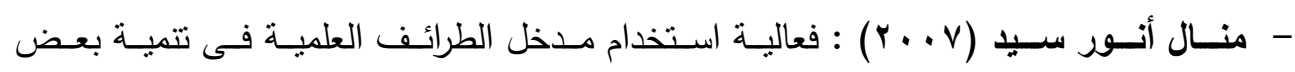
المفاهيم العلمية لدى أطفال مـا قبل المدرسـة ، رسالة ماجستير ، كلية التربية -

$$
\text { جامعة أسيوط . }
$$

- منى محمود كحلة (r . . r) ) برنامج مقترح لتدريس الطباعة اليدوية لطفل مرحلة الرياض من سـن ع - 7 سـنوات مسن خـلال التشكيل الورقى ، رسـالة ماجستير ، كليـة التربيـة

$$
\text { النوعية -جامعة|لقاهرة . }
$$

- نبيل عبد القتاح ، عبد الرحمن سليمان ( . . . . ) : علم النفس الاجتماعى ، القاهرة ، مكتبة

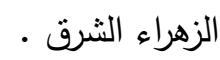


أ أد / ماجدة هاشم بخيت

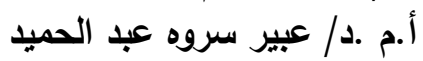

أثر أستخدام استراتيجية التعلم التعاونى

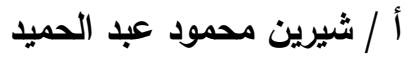

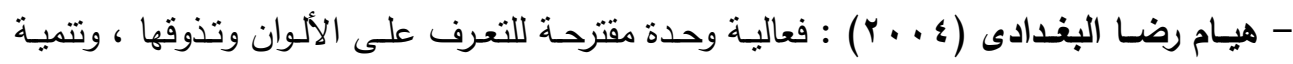
مهارات التلوين لدى أطفال الرياض ، رسالة ماجستير ، معهد الدراسات والبحوث التربوية ، جامعة القاهرة · ماكن

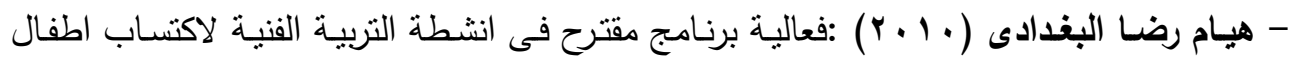
الريـاض المهارات الفنية وتتميـة بعض المفاهيم الحياتيـة وقدراتهم على الابداع ، رسالة دكتوراه ، كلية التربية ، جامعة اسيوط .

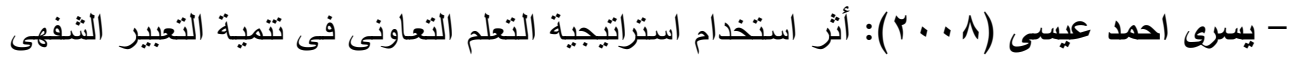
وبعض المهارات الاجتماعية لدى الدراسين فى فصول محو الامية ذوى صعوبات التعلم ، رسالة دكتوراه ، كلية التزبية ، جامعة اسيوط. 


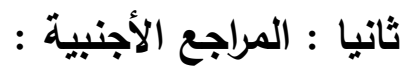

-Anderson,J.8 Goter,r. (1998): Home kits, home visits journal of young Childern, VD .53,NO .PP 71:74.

- Carolyn Holm(1998) : Every day art for kids . New York: long man. p 62.

- D.Judy Herr(1990): C.H.E. Working with young children . South Holland Wisconsin will cox company . inc., p.199.

- Li,v. (2001): An Experimental study on the effects of appreciation on Chinese writing abilitykindergardenhttp://www.learningcon ference.com/2001/abstracts/li.vanessa.html.

- SLAVIN , R .E.(1991) : Student twem learning apractical guide to co operative learning . third edition, national eduction associaaaaaation Washington d.c,p.12. 